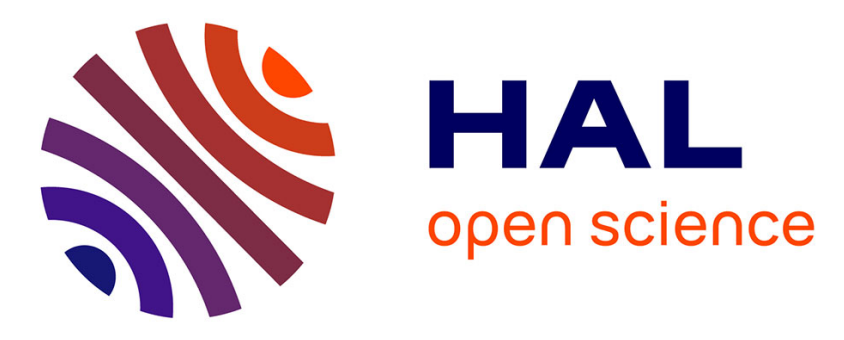

\title{
New insights into the origin and distribution of the DUPAL isotope anomaly in the Indian Ocean mantle from MORB of the Southwest Indian Ridge
}

Meyzen M.C., Ludden J.N., E. Humler, C. Mével, B. Luais, M. Storey, M. Toplis

\section{To cite this version:}

Meyzen M.C., Ludden J.N., E. Humler, C. Mével, B. Luais, et al.. New insights into the origin and distribution of the DUPAL isotope anomaly in the Indian Ocean mantle from MORB of the Southwest Indian Ridge. Geochemistry, Geophysics, Geosystems, 2005, 6 (11), pp.Q11K11. 10.1029/2005GC000979 . hal-00116039

\section{HAL Id: hal-00116039 \\ https://hal.science/hal-00116039}

Submitted on 12 Feb 2021

HAL is a multi-disciplinary open access archive for the deposit and dissemination of scientific research documents, whether they are published or not. The documents may come from teaching and research institutions in France or abroad, or from public or private research centers.
L'archive ouverte pluridisciplinaire HAL, est destinée au dépôt et à la diffusion de documents scientifiques de niveau recherche, publiés ou non, émanant des établissements d'enseignement et de recherche français ou étrangers, des laboratoires publics ou privés. 


\title{
New insights into the origin and distribution of the DUPAL isotope anomaly in the Indian Ocean mantle from MORB of the Southwest Indian Ridge
}

\author{
Christine M. Meyzen \\ Danish Lithosphere Centre (DLC), Øster Voldgade 10, 1350 Copenhagen, Denmark
}

Now at Laboratoire de Sciences de la Terre, UMR 5570, Ecole Normale Supérieure de Lyon, 46 Allée d'Italie, F-69364 Lyon Cedex 7, France (christine.meyzen@ens-lyon.fr)

\section{John N. Ludden and Eric Humler}

Laboratoire de Géosciences Marines, Institut de Physique du Globe (IPG), 4 Place Jussieu, F-75251 Paris Cedex 05, France (john.ludden@cnrs-dir.fr; bumler@ccr.jussieu.fr)

\section{Béatrice Luais}

Centre de Recherches Pétrographiques et Géochimiques (CRPG-CNRS), UPR 2300, 15 Rue Notre-Dame-des-Pauvres, BP20, F-54501 Vandoeuvre-Les-Nancy, France (luais@crpg.cnrs-nancy.fr)

\section{Michael J. Toplis}

Dynamique Terrestre et Planétaire, UMR 5562, Observatoire Midi-Pyrénées, 14 Avenue Edouard Belin, Toulouse, F-31400 France (toplis@pontos.cst.cnes.fr)

\section{Catherine Mével}

Laboratoire de Géosciences Marines, Institut de Physique du Globe (IPG), 4 Place Jussieu, F-75251 Paris Cedex 05, France(mevel@ipgp.jussieu.fr)

\section{Michael Storey}

Quaternary Dating Laboratory (QUAD-Lab), Teksam, Building 11.1, Roskilde University Centre, P.O. Box 260, DK-4000 Roskilde, Denmark(storey@ruc.dk)

[1] We report new $\mathrm{Sr}, \mathrm{Nd}$, and $\mathrm{Pb}$ isotope data for Mid-Ocean Ridge Basalts (MORB) dredged between 35 and $69^{\circ} \mathrm{E}$ along a $\sim 4100 \mathrm{~km}$ section of the Southwest Indian Ridge (SWIR), which is one of the slowest spreading ridges of the global mid-ocean ridge system (full rate of $16 \mathrm{~mm} \mathrm{yr}^{-1}$ ). The SWIR appears isotopically more heterogeneous than other mid-ocean ridges over similar length scales and comparable sampling density. Isotopic variations are generally independent of ridge segmentation, and the degree of heterogeneity decreases from west to east. This decrease in heterogeneity correlates with the observed increase in axial depth and decrease in crustal thickness, commonly attributed to decreasing mantle potential temperature. Data for the easternmost SWIR in the vicinity of the Indian Triple Junction confirm that these lavas are isotopically distinct from those of the Triple Junction, the Southeast Indian Ridge, and the Central Indian Ridge, reflecting the presence of an isotopic boundary over an along-axis distance of less than $78 \mathrm{~km}$. Results for lavas from the $39-41^{\circ} \mathrm{E}$ section extend the isotopic range of MORB to the lowest ${ }^{206} \mathrm{~Pb} /{ }^{204} \mathrm{~Pb}$ values (to 16.58 ) yet found among oceanic islands and spreading centers worldwide and confirm their extremely anomalously high ${ }^{87} \mathrm{Sr} /{ }^{86} \mathrm{Sr},{ }^{207} \mathrm{~Pb} /{ }^{204} \mathrm{~Pb}$, and ${ }^{208} \mathrm{~Pb} /{ }^{204} \mathrm{~Pb}$ and low ${ }^{143} \mathrm{Nd} /{ }^{144} \mathrm{Nd}$. This extreme Indian signature does not bear any isotopic affinities with recent products of the nearby Marion hot spot. Furthermore, the presence of old subducted marine sediment as a source for the low ${ }^{206} \mathrm{~Pb} /{ }^{204} \mathrm{~Pb}$ component is excluded, as no sediment group has the appropriate parent-daughter $\mathrm{Th} /$ $\mathrm{Pb}$ and $\mathrm{U} / \mathrm{Pb}$ characteristics to yield such compositions, not even when dewatering subduction processes are considered. Incorporation of old subduction-modified mantle into the MORB source does not yield high enough ${ }^{207} \mathrm{~Pb} /{ }^{204} \mathrm{~Pb}$ and ${ }^{208} \mathrm{~Pb} /{ }^{204} \mathrm{~Pb}$ to explain the features of lavas from the $39-41^{\circ} \mathrm{E}$ section. The 
unusual isotopic attributes of this section (low ${ }^{206} \mathrm{~Pb} /{ }^{204} \mathrm{~Pb}$ and ${ }^{143} \mathrm{Nd} /{ }^{144} \mathrm{Nd}$ and high ${ }^{87} \mathrm{Sr} /{ }^{86} \mathrm{Sr}$, ${ }^{207} \mathrm{~Pb} /{ }^{204} \mathrm{~Pb}$, and ${ }^{208} \mathrm{~Pb} /{ }^{204} \mathrm{~Pb}$ ) are best explained by the presence of stranded lower continental crust embedded in the upper mantle. This component is also inferred to be present in MORB from other spreading centers in the Indian Ocean.

Components: 17,182 words, 16 figures, 3 tables.

Keywords: Southwest Indian Ridge; MORB; isotopes; Indian Ocean; lower crust; mantle.

Index Terms: 1025 Geochemistry: Composition of the mantle; 1032 Geochemistry: Mid-oceanic ridge processes (3614, 8416); 1040 Geochemistry: Radiogenic isotope geochemistry.

Received 24 March 2005; Revised 9 July 2005; Accepted 29 August 2005; Published 10 November 2005.

Meyzen, C. M., J. N. Ludden, E. Humler, B. Luais, M. J. Toplis, C. Mével, and M. Storey (2005), New insights into the origin and distribution of the DUPAL isotope anomaly in the Indian Ocean mantle from MORB of the Southwest Indian Ridge, Geochem. Geophys. Geosyst., 6, Q11K11, doi:10.1029/2005GC000979.

Theme: Accretionary Processes Along the Ultra-Slow Spreading Southwest Indian Ridge (SWIR) Guest Editors: Catherine Mevel and Daniel Sauter

\section{Introduction}

[2] Over the last twenty years, isotopic studies of Mid-Ocean Ridge Basalts (MORB) have established the existence of a vast mantle isotopic domain in the Indian Ocean, which distinguishes this mantle source from that of the Pacific and north Atlantic [Dupré and Allègre, 1983; Hart, 1984; Hamelin and Allègre, 1985; Hamelin et al., 1986; Price et al., 1986; Michard et al., 1986; Klein et al., 1988; Dosso et al., 1988; Mahoney et al., 1989, 1992, 1996, 1998, 2002; Pyle et al., 1992, 1995; Kempton et al., 2002; Escrig et al., 2004; Hanan et al., 2004]. Along the present Indian ocean spreading axis, this domain includes the entire Central Indian and Carlsberg Ridges, stretching from about $126^{\circ} \mathrm{E}$ on the Southeast Indian Ridge [Klein et al., 1988; Pyle et al., 1992, 1995], from $26^{\circ} \mathrm{E}$ on the Southwest Indian Ridge [Mahoney et al., 1992] and northward into the Red Sea [Schilling et al., 1992].

[3] When compared to Atlantic and Pacific MORB, Indian MORB are characterized by distinctly lower ${ }^{206} \mathrm{~Pb} /{ }^{204} \mathrm{~Pb}$ and ${ }^{143} \mathrm{Nd} /{ }^{144} \mathrm{Nd}$ and higher ${ }^{87} \mathrm{Sr} /{ }^{86} \mathrm{Sr}$, as well as systematically higher ${ }^{207} \mathrm{~Pb} /{ }^{204} \mathrm{~Pb}$ and ${ }^{208} \mathrm{~Pb} /{ }^{204} \mathrm{~Pb}$ at a given ${ }^{206} \mathrm{~Pb} /{ }^{204} \mathrm{~Pb}$ [Hart, 1984]. These distinct characteristics have been attributed to the widespread dispersal, in the Indian Ocean mantle of material derived from one or more of the following: (1) Indian ocean hot spot sources, especially from the large long-lived Kerguelen mantle plume [e.g., Storey et al.,
1989]; (2) continental lithospheric mantle introduced prior to and/or during the breakup of Gondwana [e.g., Mahoney et al., 1992]; (3) convectively recycled subducted altered oceanic crust and/or sediment [e.g., Dupré and Allègre, 1983; Rekhämper and Hofmann, 1997]; (4) continental crust from cratonic Gondwanan lithosphere [e.g., Arndt and Goldstein, 1989; Escrig et al., 2004; Hanan et al., 2004]; (5) subduction-modified mantle [e.g., Kempton et al., 2002]. Thus, despite its extent, the history and origin of this province are not yet well understood.

[4] In this respect, the $\mathrm{Pb}-\mathrm{Sr}-\mathrm{Nd}$ isotopic compositions of MORB from the Southwest Indian Ridge (SWIR) which is an ultra-slow spreading ridge (full rate $<20 \mathrm{~mm} \mathrm{yr}^{-1}$ ) stretching from the Bouvet Triple Junction $\left(55^{\circ} \mathrm{S}, 00^{\circ} 40^{\prime} \mathrm{W}\right)$ to the Rodrigues Triple Junction (RTJ, $25^{\circ} 30^{\prime} \mathrm{S}, 70^{\circ} \mathrm{E}$ ) are of particular interest, as they define a gradual isotopic transition in the MORB source mantle from typical Indian Ocean-type composition in the east to Atlantic like ones, west of $26^{\circ} \mathrm{E}$ [Mahoney et al., 1992]. Nonetheless, previous isotopic studies of MORB from the eastern extremity of the SWIR involve only limited reconnaissance data and sparse sampling along the axis [Hamelin and Allègre, 1985; Michard et al., 1986, Price et al., 1986; Mahoney et al., 1989, 1992; Robinson et al., 2001]. The easternmost SWIR section is morphologically an intriguing section as it is characterized by a very deep axial valley (4730 $\mathrm{m}$ on average), thick lithosphere and 
extremely thin oceanic crust (4-5 km on average) [Francis and Raitt, 1967; Minshull and White, 1996; Cannat et al., 1999; Müller et al., 1999]. These attributes have been interpreted to reflect a weak magma supply from an underlying mantle which is unusually cold. Previous studies on the easternmost segments of the SWIR mainly investigated the regional provinciality around the Rodrigues Triple Junction (RTJ), and demonstrated that SWIR lavas from the deep eastern extremity differ chemically and isotopically from those of the Southern Central Indian Ridge (CIR), the western Southeast Indian Ridge (SEIR) and the RTJ [Michard et al., 1986; Price et al., 1986; Mahoney et al., 1989; Meyzen et al., 2003]. This provinciality was ascribed either to the eastward progression of a distinct SWIR mantle in response to the migration of the junction [Mahoney et al., 1989] or to sampling of a vertically zoned mantle [Mahoney et al., 1989]. The SWIR eastern extremity near the RTJ was thus identified as a distinct isotopic province although there was no clear definition of its extension to the west.

[5] The central part of the SWIR has been extensively studied [e.g., LeRoex et al., 1989; Mahoney et al., 1992], but most samples were either dredged off-axis or in the transform faults. As a consequence, they did not provide a complete perspective of the along-axis geochemical variations of the SWIR mantle. In this area, the ridge is characterized by a dense network of transform faults and is surrounded by several oceanic islands and aseismic ridges (Prince Edward Island, Marion Island, Funk seamount, Madagascar plateau, Del Cano Rise and Crozet Plateau) marking the locus of the Marion and Crozet hot spots [Mahoney et al., 1992]. One of the most noticeable features of lavas erupted in this area is their large isotopic compositional diversity, which cannot be simply supported by a simple model of ridge-ward flow plumes like those established on faster ridges [Mahoney et al., 1992]. With the exception of the $36-39^{\circ} \mathrm{E}$ section, near Crozet and Marion Islands, isotopic signatures of MORB show no obvious affinities with those of Marion and Crozet hot spots [Mahoney et al., 1992]. Between 39 and $41^{\circ} \mathrm{E}$, basalts exhibit one of the most pronounced Indian Ocean isotope signatures (e.g., low ${ }^{206} \mathrm{~Pb} /{ }^{204} \mathrm{~Pb}$ and ${ }^{143} \mathrm{Nd} /{ }^{144} \mathrm{Nd}$, high ${ }^{207} \mathrm{~Pb} /{ }^{204} \mathrm{~Pb},{ }^{208} \mathrm{~Pb} /{ }^{204} \mathrm{~Pb}$ and ${ }^{87} \mathrm{Sr} /{ }^{86} \mathrm{Sr}$ [Mahoney et al., 1992]).

[6] Here, we present new $\mathrm{Sr}-\mathrm{Nd}$ and $\mathrm{Pb}$ isotope data, including the lowest ${ }^{206} \mathrm{~Pb} /{ }^{204} \mathrm{~Pb}$ yet observed for oceanic-mantle derived rocks, for basaltic glasses and basalts dredged between $35^{\circ}$ and $69^{\circ} \mathrm{E}$ along the SWIR neovolcanic zone during the SWIFT (winter 2001, R/V Marion Dufresne) and EDUL (summer 1997, R/V Marion Dufresne) cruises. Our results thus provide a much improved and precise perspective of the along-axis geochemical variations of the SWIR mantle. The precision of the $\mathrm{Pb}$ double-spike technique permits a fine scale assessment of the distribution of MORB heterogeneity along the SWIR, in a region where extreme isotope variations provide a key to understanding the distinctive nature of the Indian Ocean mantle.

\section{Geological Setting}

[7] The SWIR separates the African and Antarctic plates over a distance of $\sim 7700 \mathrm{~km}$, and has been active for more than $100 \mathrm{Ma}$ [Patriat et al., 1997; Marks and Tikku, 2001]. In the eastern section sampled for this study $\left(35^{\circ}\right.$ to $\left.69^{\circ} \mathrm{E}\right)$, the ridge axis is offset by several spectacular long-lived north-south trending transform faults (Figure 1). In its central part, the ridge is surrounded by several oceanic islands and aseismic ridges marking the locus of Marion and Crozet hot spots (Figure 1). Marion Island, which is located at about $250 \mathrm{~km}$ south of the ridge axis, marks the current position of the Marion plume. The present-day surface expression of the Crozet hot spot may be either the Crozet archipelago [Currey and Munasinghe, 1991] or the Conrad Rise [Müller et al., 1993]. A large regional positive residual geoid anomaly $\left(32-55^{\circ} \mathrm{E}\right)$ is centered mid-way between Crozet and Marion Islands [LeRoex et al., 1989]. Between 35 and $69^{\circ} \mathrm{E}$ seafloor morphology defines four contrasting domains with distinct segmentation styles: a very deep $(4730 \mathrm{~m})$ and slightly oblique $\left(25^{\circ}\right)$ domain to the east of the Melville FZ (zone A); a deep $(4330 \mathrm{~m})$ and oblique $\left(40^{\circ}\right)$ domain from the Melville $\mathrm{FZ}$ to the Gallieni FZ (zone B); a very shallow (3090$3530 \mathrm{~m}$ ) and oblique domain $\left(40^{\circ}\right)$ from the Gallieni FZ to the Discovery $\Pi$ FZ (Zone C); a shallow $(3050 \mathrm{~m})$ and oblique domain west of the Discovery $\Pi$ FZ (zone D) (Figure 1) [Mendel et al., 1997, 2003; Cannat et al., 1999; Sauter et al., 2001]. Within the deepest part of the studied area (zone A), the extremely complex along-axis segmentation pattern is not correlated with the gravimetric segmentation [Cannat et al., 1999], leaving a chaotic off-axis seafloor terrain over the last 20 Myr [Parson et al., 1997; Patriat et al., 1997]. 


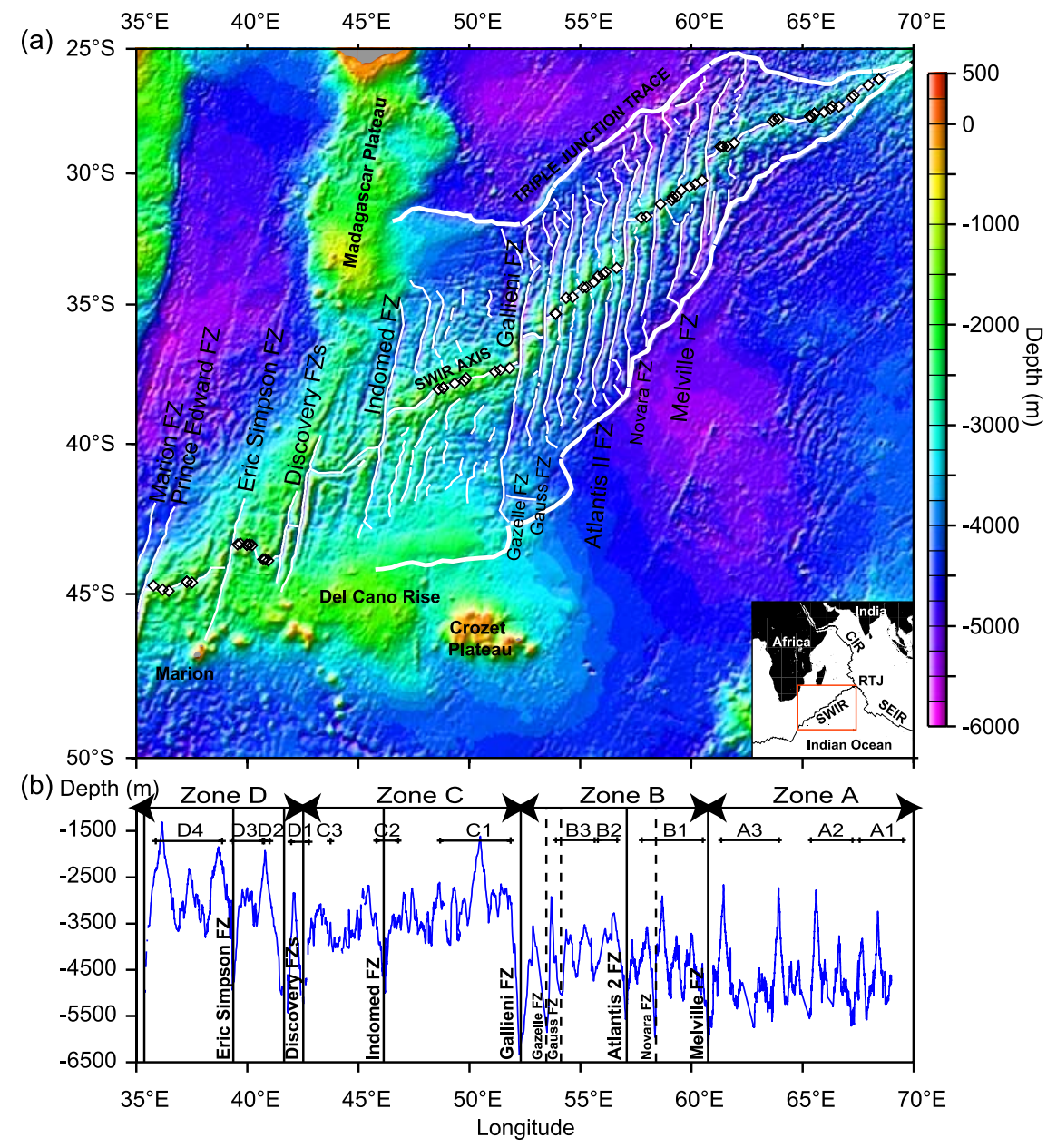

Figure 1. (a) Topographic map of the SWIR from Smith and Sandwell [1997] showing sample locations used in this study (open diamonds). (b) Axial bathymetric profile versus longitude ( $\left.{ }^{\circ} \mathrm{E}\right)$ [Cannat et al., 1999; Mendel et al., 2003]. The zones defined by seafloor morphology variations are labeled A-D. Within these zones, isotopic domains are labeled by increasing number going westward. Major (continuous lines) and minor (dashed lines) Fracture Zones (FZ) are also shown. Inset shows regional location of the study area (box): Rodrigues Triple Junction (RTJ), Southeast Indian Ridge (SEIR), and Central Indian Ridge (CIR).

These features have been ascribed to either episodic but intense volcanic activity [Cannat et al., 1999], to restricted and intermittent mantle diapirism [Mendel et al., 1997], or to the temporal evolution of the RTJ configuration [Patriat et al., 1997]. The presence of rare very high volcanic constructions (maximum height: $2672 \mathrm{~m}$ above seafloor) requires the presence of a thick lithosphere [Cannat et al., 1999]. In contrast, between the Gallieni and Atlantis $\Pi$ FZ, the axial segmentation pattern is well defined and broadly continuous over the past $40 \mathrm{Myr}$ [Sauter et al., 2001]. To the west of the Gallieni FZ (zone C), as observed for zone A, the along-axis segmentation leaves no clear off-axis trace for the last $15 \mathrm{Myr}$. This change of segmentation pattern, either side of the Gallieni FZ, has been attributed to the temporal evolution of the RTJ configuration [Sauter et al., 2001]. Within zone C, mean axial depth is greater and segments are shorter than to the west of the Discovery FZ [Mendel et al., 2003]. Between the Indomed FZ $\left(46^{\circ} \mathrm{E}\right)$ and Gallieni FZ $\left(52^{\circ} 20^{\prime} \mathrm{E}\right)$, the presence of axial bathymetric highs and gravity lows reflect either remnant effects of the Del Cano Rise or excess volcanism due to the off-axis Crozet plume [Georgen et al., 2001]. Within zone $\mathrm{D}$, between the Andrew Bain FZ $\left(32^{\circ} 18^{\prime} \mathrm{E}\right)$ and Discovery $\Pi \mathrm{FZ}$, evidence for an interaction of the ridge with the Marion hot spot is provided by pronounced axial gravity lows and shallow axial depth over $1100 \mathrm{~km}$ [Georgen et al., 2001; Georgen and Lin, 2003]. Off-axis, these gravity lows extend from Marion Island 
Table 1. $\mathrm{Sr}, \mathrm{Nd}$, and $\mathrm{Pb}$ Isotopic Data for SWIR Basalts and Basaltic Glasses, $35^{\circ}-69^{\circ} \mathrm{E}^{\mathrm{a}}$

\begin{tabular}{|c|c|c|c|c|c|c|c|c|c|c|c|c|}
\hline Sample & $\begin{array}{l}\text { Lat., } \\
{ }^{\circ} \mathrm{S}\end{array}$ & $\begin{array}{l}\text { Long., } \\
{ }^{\circ} \mathrm{E}\end{array}$ & $\begin{array}{l}\text { Depth, } \\
\text { m }\end{array}$ & Zone & ${ }^{206} \mathrm{~Pb} /{ }^{204} \mathrm{~Pb}$ & $2 \sigma$ & ${ }^{207} \mathrm{~Pb} /{ }^{204} \mathrm{~Pb}$ & $2 \sigma$ & ${ }^{208} \mathrm{~Pb} /{ }^{204} \mathrm{~Pb}$ & $2 \sigma$ & ${ }^{87} \mathrm{Sr} /{ }^{86} \mathrm{Sr}$ & ${ }^{143} \mathrm{Nd} /{ }^{144} \mathrm{Nd}$ \\
\hline \multirow[t]{3}{*}{ ED-DR1-1-1 } & 26.10 & 68.73 & 4775 & A1 & 18.1419 & 0.0008 & 15.4664 & 0.0009 & 37.9818 & 0.0019 & 0.702964 & 0.513034 \\
\hline & & & & & 18.1426 & 0.0009 & 15.4674 & 0.0009 & 37.9857 & 0.0020 & - & - \\
\hline & & & & & 18.1441 & 0.0025 & 15.4691 & 0.0024 & 37.9934 & 0.0058 & - & - \\
\hline \multirow[t]{2}{*}{$\begin{array}{l}\text { ED-DR2 } \\
\text { Glass stn }\end{array}$} & 26.23 & 68.44 & 3755 & A1 & 17.9841 & 0.0021 & 15.4557 & 0.0018 & 37.7952 & 0.0045 & 0.702914 & 0.513068 \\
\hline & & & & & - & - & - & - & - & - & - & 0.513103 \\
\hline ED-DR2-1-1 & 26.23 & 68.44 & 3755 & $\mathrm{~A} 1$ & 17.9881 & 0.0017 & 15.4594 & 0.0018 & 37.8052 & 0.0041 & 0.702954 & 0.513042 \\
\hline \multirow[t]{2}{*}{ ED-DR3-2-1 } & 26.49 & 67.98 & 4750 & A1 & 17.9716 & 0.0015 & 15.4580 & 0.0014 & 37.8186 & 0.0033 & 0.702896 & 0.513069 \\
\hline & & & & & 17.9731 & 0.0020 & 15.4583 & 0.0019 & 37.8183 & 0.0046 & - & 0.513047 \\
\hline $\begin{array}{l}\text { ED-DR5 } \\
\text { Glass stn }\end{array}$ & 26.89 & 67.32 & 4113 & $\mathrm{~A} 2$ & - & - & - & - & - & - & 0.702867 & 0.513062 \\
\hline ED-DR6-4-1 & 26.98 & 67.23 & 4700 & $\mathrm{~A} 2$ & 17.8906 & 0.0028 & 15.4585 & 0.0028 & 37.8276 & 0.0065 & 0.703120 & 0.513015 \\
\hline ED-DR7-2-5 & 27.35 & 66.65 & 3725 & A2 & 18.07 & 0.0011 & 15.48 & 0.0011 & 38.0 & 0.0024 & 0.703234 & 0.513013 \\
\hline \multirow[t]{3}{*}{ ED-DR8-2 } & 27.34 & 66.34 & 4375 & $\mathrm{~A} 2$ & 17.7783 & 0.0009 & 15.4410 & 0.0008 & 37.6 & 0.0020 & 0.702966 & 0.513050 \\
\hline & & & & & 17.7814 & 0.0022 & 15.4444 & 0.0020 & 37.6998 & 0.0048 & 0.702924 & 0.513079 \\
\hline & & & & & 17.7742 & 0.0004 & 15.4341 & 0.0003 & 37.6729 & 0.0010 & - & - \\
\hline \multirow[t]{2}{*}{ ED-DR9-3-1 } & 27.44 & 66.26 & 4350 & A2 & 17.9184 & 0.0014 & 15.4583 & 0.0014 & 37.8354 & 0.0032 & 0.703122 & 0.513018 \\
\hline & & & & & 17.9121 & 0.0004 & 15.4551 & 0.0005 & 37.8351 & 0.0014 & - & - \\
\hline ED-DR10-1-4 & 27.57 & 65.98 & 4310 & $\mathrm{~A} 2$ & 17.8274 & 0.0014 & 15.4469 & 0.0014 & 37.7084 & 0.0032 & 0.702889 & 0.513065 \\
\hline \multirow{3}{*}{ ED-DR11-1-9 } & 27.63 & 65.54 & 3475 & $\mathrm{~A} 2$ & 18.0417 & 0.0008 & 15.4971 & 0.0008 & 38.1582 & 0.0017 & 0.703626 & 0.512885 \\
\hline & & & & & 18.0385 & 0.0021 & 15.4936 & 0.0020 & 38.1 & 0.0046 & 0.703610 & 0.512859 \\
\hline & & & & & 18.0 & 0.0006 & 15.5 & 0.0005 & 38. & 0.0015 & - & - \\
\hline ED-DR11-1-2 & 27.63 & 65.54 & 3475 & $\mathrm{~A} 2$ & 18.0 & 0.0022 & 15.4 & 0036 & 38.1 & 0.0073 & 0.703626 & 0.512911 \\
\hline \multirow[t]{4}{*}{ ED-DR12-1-2 } & 27.74 & 65.35 & 5375 & $\mathrm{~A} 2$ & 17.8909 & 0.0009 & 15.4 & 0.0009 & 37.8 & 0.0020 & 0.702916 & 0.513080 \\
\hline & & & & & 17.8859 & 0.0034 & 15.4488 & 0.0028 & 37.7940 & 0.0067 & - & 0.513067 \\
\hline & & & & & 17.8881 & 0.0018 & 15.4515 & 0.0017 & 37.8028 & 0.0042 & - & - \\
\hline & & & & & 17.8870 & 0.0006 & 15.4529 & 0.0007 & 37.8114 & 0.0020 & - & - \\
\hline \multirow[t]{3}{*}{ ED-DR12-3-2 } & 27.74 & 65.35 & 5375 & A2 & 17.8856 & 0.0019 & 15.4480 & 0.0019 & 37.7925 & 0.0054 & 0.702941 & 0.513042 \\
\hline & & & & & 17.8841 & 0.0024 & 15.4460 & 0.0022 & 37.7854 & 0.0053 & 0.702944 & 0.513007 \\
\hline & & & & & - & - & - & - & - & - & 0.702904 & - \\
\hline \multirow[t]{2}{*}{$\begin{array}{l}\text { ED-DR13 } \\
\text { tube }\end{array}$} & 27.78 & 65.42 & 5175 & $\mathrm{~A} 2$ & 17.8093 & 0.0009 & 15.4487 & 0.0018 & 37.7479 & 0.0029 & 0.703052 & 0.513027 \\
\hline & & & & & & & & & & & & 513037 \\
\hline $\begin{array}{l}\text { ED-DR16 } \\
\text { Tube }\end{array}$ & 27.85 & 63.92 & 2850 & A3 & 17.7976 & 0.0016 & 15.4343 & 0.0016 & 37.6335 & 0.0044 & 0.702777 & 0.513069 \\
\hline \multirow[t]{2}{*}{ ED-DR19-1-3 } & 27.86 & 63.75 & 4475 & A3 & 17.8003 & 0.0010 & 15.4348 & .0011 & 37.6637 & 0.00 & 0.702795 & - \\
\hline & & & & & 17.7962 & 0.0006 & & 0.0006 & & & 0.702819 & - \\
\hline \multirow[t]{2}{*}{ ED-DR20-1-1 } & 27.93 & 63.66 & 4675 & A3 & 18.0280 & 0.0027 & 15.4664 & 0.0026 & 37.8453 & 0.0064 & 0.702710 & 0.513152 \\
\hline & & & & & & & 15.4642 & & & & - & - \\
\hline ED-DR26-1 & 28.80 & 61.93 & 4520 & A3 & 17.9929 & 0.0071 & 15.4874 & & 37.9842 & & 0.702868 & 0.513055 \\
\hline \multirow[t]{2}{*}{$\begin{array}{l}\text { ED-DR27 } \\
\text { tube }\end{array}$} & 28.94 & 61.64 & 4375 & A3 & 17.9282 & 0.0035 & 15.4535 & 0.0035 & 37.7838 & 0.0081 & 0.702748 & 0.513108 \\
\hline & & & & & - & - & - & - & - & - & - & 0.513148 \\
\hline ED-DR28-2-5 & 28.95 & 61.44 & 2750 & A3 & 17.746 & 0.0015 & 15.43 & 0014 & 37.5 & 0.00 & 0.702747 & 123 \\
\hline \multirow[t]{2}{*}{ ED-DR29-1-1 } & 28.95 & 61.32 & 3550 & A3 & 17.6819 & 0.0027 & 15.4307 & 0.0026 & 37.5406 & 0.0062 & 0.702749 & 0.513097 \\
\hline & & & & & 17.6790 & 0.0031 & & & 37.5321 & 0.0066 & 0.702755 & 0.513104 \\
\hline ED-DR29-1-2 & 28.95 & 61.32 & 3550 & A3 & 17.6775 & 0.0017 & 15.4279 & 0.0016 & 37.5334 & 0.0037 & 0.702721 & 0.513092 \\
\hline ED-DR32-4-4 & 30.27 & 60.49 & 4450 & B1 & 17.4498 & 0.0020 & 15.4023 & 0.0020 & 37.1346 & 0.0045 & 0.702749 & 0.513172 \\
\hline \multirow[t]{2}{*}{ ED-DR34-1-3 } & 30.43 & 60.16 & 4450 & B1 & 17.4023 & 0.0010 & 15.3962 & 0.0012 & 37.0778 & 0.0023 & 0.702659 & 0.513215 \\
\hline & & & & & 17.4052 & 0.0014 & 15.3976 & 0.0017 & 37.0816 & 0.0036 & - & - \\
\hline \multirow{2}{*}{$\begin{array}{l}\text { ED-DR35 } \\
\text { pot4 }\end{array}$} & 30.52 & 59.91 & 4250 & B1 & 17.4018 & 0.0014 & 15.4006 & 0.0014 & 37.1097 & 0.0038 & 0.702911 & 0.513125 \\
\hline & 30.52 & & & B & - & - & - & - & - & - & 0.702953 & 0.513118 \\
\hline \multirow{3}{*}{$\begin{array}{l}\text { ED-DR36 } \\
\text { Tube }\end{array}$} & 30.66 & 59.56 & 4350 & B1 & 17.4323 & 0.0012 & 15.4014 & 0.0012 & 37.1355 & 0.0032 & 0.702774 & 0.513160 \\
\hline & & & & & 17.4320 & 0.0013 & 15.4005 & 0.0013 & 37.1335 & 0.0035 & - & 0.513130 \\
\hline & & & & & - & - & - & - & - & - & - & 0.513129 \\
\hline ED-DR38-1-1 & 30.91 & 59.33 & 3875 & B1 & 17.4224 & 0.0013 & 15.4013 & 0.0013 & 37.1104 & 0.0029 & 0.702829 & 0.513134 \\
\hline & & & & & - & - & - & - & - & - & - & 0.513178 \\
\hline ED-DR41-1-1 & 30.92 & 59.16 & 4275 & B1 & 17.3631 & 0.0013 & 15.3923 & 0.0012 & 37.0698 & 0.0029 & 0.702824 & 0.513157 \\
\hline
\end{tabular}


Table 1. (continued)

\begin{tabular}{|c|c|c|c|c|c|c|c|c|c|c|c|c|}
\hline Sample & $\begin{array}{l}\text { Lat., } \\
{ }^{\circ} \mathrm{S}\end{array}$ & $\begin{array}{l}\text { Long., } \\
{ }^{\circ} \mathrm{E}\end{array}$ & $\begin{array}{l}\text { Depth, } \\
\text { m }\end{array}$ & Zone & ${ }^{206} \mathrm{~Pb} /{ }^{204} \mathrm{~Pb}$ & $2 \sigma$ & ${ }^{207} \mathrm{~Pb} /{ }^{204} \mathrm{~Pb}$ & $2 \sigma$ & ${ }^{208} \mathrm{~Pb} /{ }^{204} \mathrm{~Pb}$ & $2 \sigma$ & ${ }^{87} \mathrm{Sr} /{ }^{86} \mathrm{Sr}$ & ${ }^{143} \mathrm{Nd} /{ }^{144} \mathrm{Nd}$ \\
\hline $\begin{array}{l}\text { ED-DR42 } \\
\text { glass stn }\end{array}$ & 1.05 & 59.12 & 4500 & B1 & 17.4040 & 0.0010 & 15.3980 & 0.0012 & 37.0847 & 0.0035 & 0.702723 & 0.513167 \\
\hline & & & & & 17.4032 & 0.0011 & 15.3966 & 0.0013 & 37.0818 & 0.0039 & - & 0.513143 \\
\hline ED-DR46-1-6 & 1.19 & 58.61 & 4050 & B1 & & .0035 & & .0034 & 37. & .0081 & 0.702707 & 170 \\
\hline $\begin{array}{c}\text { ED-DR48 } \\
\text { Tube }\end{array}$ & 31.69 & 57.97 & 3600 & B1 & 17.5354 & 0.0010 & 15.4181 & 0.0011 & 37.2715 & 0.0030 & 0.702950 & 0.513096 \\
\hline & & & & & 17.5312 & 0.0014 & 15.4134 & 0.0016 & 37.2579 & 0.0034 & - & - \\
\hline ED-DR49 pot & 31.73 & 57.74 & 3975 & B1 & $\begin{array}{c}17.4960 \\
-\end{array}$ & $\begin{array}{c}0.0019 \\
-\end{array}$ & $\begin{array}{c}15.4134 \\
-\end{array}$ & $\begin{array}{c}0.0019 \\
-\end{array}$ & $\begin{array}{c}37.2152 \\
-\end{array}$ & $\begin{array}{c}0.0043 \\
-\end{array}$ & $\begin{array}{l}0.702851 \\
0.702861\end{array}$ & $\begin{array}{c}0.513134 \\
-\end{array}$ \\
\hline ED-DR51-1-1 & 33.65 & 56.64 & 3675 & B2 & & & & & & $\begin{array}{l}\mathbf{0 . 0 0 4 0} \\
0.0069\end{array}$ & $\begin{array}{c}0.702822 \\
-\end{array}$ & $\begin{array}{c}0.513073 \\
-\end{array}$ \\
\hline $\begin{array}{l}\text { ED-DR } 52 \\
\text { Glass stn }\end{array}$ & 33.79 & 56.13 & 3550 & B2 & 18.1278 & 0.0020 & 15.4867 & 0.0020 & 37.7668 & 0.0056 & 0.702732 & 0.513097 \\
\hline ED-DR53-2-3 & 33.87 & 56.03 & 3150 & B2 & 18.0786 & 0.0026 & 15.4773 & 0.0024 & 37.7434 & 0.0060 & 2658 & 0.513122 \\
\hline ED-DF & 33.96 & 55.78 & 3735 & B2 & & & & & & & $\begin{array}{c}0.703177 \\
\mathbf{0 . 7 0 3 1 7 3} \\
-\end{array}$ & $\begin{array}{l}13037 \\
- \\
-\end{array}$ \\
\hline ED-DR57-1-1 & 34.15 & 55.63 & 4100 & B3 & & & & & & & $\begin{array}{c}0.702907 \\
-\end{array}$ & $\begin{array}{c}0.513072 \\
-\end{array}$ \\
\hline $\begin{array}{l}\text { ED-DR60 } \\
\text { glass stn }\end{array}$ & 34.37 & 55.26 & 3650 & B3 & 17.8398 & 0.0012 & & 0.0013 & & & 0.702943 & 0.513016 \\
\hline ED-DR61-2-4 & 34.36 & 55.13 & 3650 & B3 & 17.8931 & $\begin{array}{c}0.0013 \\
-\end{array}$ & $\begin{array}{c}15.4613 \\
-\end{array}$ & 0.0011 & $\begin{array}{c}37.7300 \\
-\end{array}$ & $\begin{array}{c}0.0028 \\
-\end{array}$ & & $\begin{array}{c}13038 \\
-\end{array}$ \\
\hline ED-DR63-1 & 34.73 & 54.65 & 3800 & B3 & & & & & $\begin{array}{c}37.6722 \\
37.6654 \\
-\end{array}$ & & $\begin{array}{c}0.702956 \\
0.702962 \\
-\end{array}$ & $\begin{array}{l}0.513054 \\
0.513077 \\
0.513063\end{array}$ \\
\hline DP 66 & .76 & 54.37 & 3725 & & 18.1221 & 00028 & & > & 37.959 & & 0.702882 & \\
\hline $\begin{array}{c}\text { ED-DR68 } \\
\text { Tube }\end{array}$ & & & & & & & & & & & 0.702973 & 0.513070 \\
\hline & & & & & & & & & & & & \\
\hline ED-DR68-1 & 35.34 & 53.89 & 4050 & B3 & $\begin{array}{l}.6024 \\
-\end{array}$ & $\begin{array}{c}0.0025 \\
-\end{array}$ & $\begin{array}{c}15.4273 \\
-\end{array}$ & $\begin{array}{c}0.0005 \\
-\end{array}$ & $\begin{array}{c}37.5315 \\
-\end{array}$ & $\begin{array}{c}0.0011 \\
-\end{array}$ & $\begin{array}{c}0.702967 \\
-\end{array}$ & \\
\hline ED-DR70-1-1 & 37.33 & 51.81 & 2875 & $\mathrm{C} 1$ & $\begin{array}{c}18.1003 \\
-\end{array}$ & $\begin{array}{c}0.0046 \\
-\end{array}$ & $\begin{array}{c}15.4952 \\
-\end{array}$ & $\begin{array}{c}0.0042 \\
-\end{array}$ & $\begin{array}{c}37.9263 \\
-\end{array}$ & $\begin{array}{c}0.0102 \\
-\end{array}$ & $\begin{array}{c}0.702987 \\
-\end{array}$ & \\
\hline & .39 & 51.39 & & & & & & & & & & 109 \\
\hline $\begin{array}{l}\text { ED-DR72 } \\
\text { Glass stn }\end{array}$ & 7.46 & 51.16 & & $\mathrm{C} 1$ & & 0.0019 & & & & & 0.703044 & 0.513104 \\
\hline & 69 & 4 & & & $\begin{array}{l}3.2019 \\
.2260\end{array}$ & 2 & $\begin{array}{l}15.5009 \\
15.4904\end{array}$ & $\begin{array}{l}.0017 \\
.0047\end{array}$ & $\begin{array}{l}0 \\
2\end{array}$ & $\begin{array}{l}.0047 \\
.0116\end{array}$ & $\begin{array}{c}0.703014 \\
0.702722\end{array}$ & \\
\hline $\begin{array}{r}\text { ED-D } \\
\text { Gla }\end{array}$ & 7.79 & 49.77 & 2300 & $\mathrm{C} 1$ & - & - & - & - & - & - & 0.702819 & 0.513111 \\
\hline$\Omega_{0}$ & .87 & & & & & & & & & & & \\
\hline & 3.03 & 48.83 & 2760 & & & & & & & & 0.702934 & 166 \\
\hline & 8.03 & 48.83 & 2760 & $\mathrm{C}$ & & & & & & & 0.702887 & 3168 \\
\hline & 38.08 & 48.62 & 2760 & $\mathrm{C} 1$ & & & & & & & 0.703157 & 3139 \\
\hline SW-DR20-1-1 & 43.92 & 40.94 & 2700 & D2 & 18.4067 & 0.0014 & 15.5268 & & & & 0.702994 & 0.513037 \\
\hline & & & & & & & & & & & 0.702993 & - \\
\hline & 3.89 & & & D & & & & & & & & \\
\hline & & 40.70 & & D2 & & & & & & & & $\begin{array}{c}0.513005 \\
-\end{array}$ \\
\hline & 43.43 & 40.21 & & & & & & & & & & \\
\hline & 43.40 & 40.10 & 2770 & D3 & $\begin{array}{l}17.2726 \\
17.2738\end{array}$ & $\begin{array}{l}0.0018 \\
0.0021\end{array}$ & $\begin{array}{l}15.4409 \\
15.4427\end{array}$ & & & & $\begin{array}{l}0.703717 \\
0.703718\end{array}$ & $\begin{array}{c}0.512871 \\
-\end{array}$ \\
\hline SW-DR13-1-2 & 43.41 & 39.98 & 2880 & D3 & $\begin{array}{l}16.5850 \\
16.5850\end{array}$ & $\begin{array}{l}0.0020 \\
0.0020\end{array}$ & $\begin{array}{l}15.3599 \\
15.3599\end{array}$ & $\begin{array}{l}0.0021 \\
0.0021\end{array}$ & $\begin{array}{l}36.8753 \\
36.8753\end{array}$ & $\begin{array}{l}0.0055 \\
0.0055\end{array}$ & $\begin{array}{l}0.704761 \\
0.704769\end{array}$ & $\begin{array}{c}0.512607 \\
-\end{array}$ \\
\hline & 43.41 & 39.98 & 2880 & D3 & & & & & & & 0.704746 & - \\
\hline SW-DR10\#3 & 43.36 & 39.69 & 3120 & D3 & 17.2434 & 0.0026 & 15.4496 & 0.0025 & 37.4273 & 0.0058 & 0.703938 & 0.512870 \\
\hline
\end{tabular}


Table 1. (continued)

\begin{tabular}{lcccccccccccc}
\hline \multicolumn{1}{c}{ Sample } & $\begin{array}{c}\text { Lat., } \\
{ }^{\circ} \mathrm{S}\end{array}$ & $\begin{array}{c}\text { Long., Depth, } \\
{ }^{\circ} \mathrm{E}\end{array}$ & $\mathrm{m}$ & Zone & ${ }^{206} \mathrm{~Pb} /{ }^{204} \mathrm{~Pb}$ & $2 \sigma$ & ${ }^{207} \mathrm{~Pb} /{ }^{204} \mathrm{~Pb}$ & $2 \sigma$ & ${ }^{208} \mathrm{~Pb} /{ }^{204} \mathrm{~Pb}$ & ${ }^{2 \sigma}$ & ${ }^{87} \mathrm{Sr} /{ }^{86} \mathrm{Sr}$ & ${ }^{143} \mathrm{Nd} /{ }^{144} \mathrm{Nd}$ \\
\hline SW-DR16-3-3 & 43.43 & 40.21 & 3100 & $\mathrm{D} 3$ & 17.2033 & 0.0015 & 15.4382 & 0.0016 & 37.4102 & 0.0045 & 0.703863 & 0.512863 \\
SW-DR9-1-3 & 44.63 & 37.50 & 2730 & $\mathrm{D} 4$ & 18.2269 & 0.0037 & 15.4992 & 0.0036 & 37.9639 & 0.0090 & 0.702788 & - \\
SW-DR8-2-1 & 44.61 & 37.27 & 2850 & D4 & 18.3562 & 0.0024 & 15.5229 & 0.0023 & 38.1451 & 0.0062 & 0.702960 & 0.513138 \\
SW-DR8-2-3 & 44.61 & 37.27 & 2850 & D4 & 18.3469 & 0.0033 & 15.5066 & 0.0030 & 38.1260 & 0.0079 & 0.703134 & - \\
SW-DR6-2-2 & 44.90 & 36.47 & 2400 & D4 & 18.2890 & 0.0020 & 15.5095 & 0.0018 & 38.0463 & 0.0050 & 0.702882 & 0.513147 \\
SW-DR5-1-2 & 44.86 & 36.18 & 1320 & D4 & 18.3663 & 0.0012 & 15.5162 & 0.0012 & 38.1243 & 0.0032 & 0.702915 & 0.513102 \\
SWR-DR4-1-2 & 44.73 & 35.78 & 2750 & D4 & 18.2423 & 0.0017 & 15.5023 & 0.0017 & 37.9802 & 0.0045 & - & 0.513179 \\
\hline
\end{tabular}

\begin{abstract}
${ }^{\text {a }}$ Samples are designated as W-X-Y-Z, indicating cruise (ED: EDUL, SW: SWIFT), dredge, sample type for each dredge, and block numbers. SWIR basalt data are in bold. All $\mathrm{Pb}, \mathrm{Sr}$, and $\mathrm{Nd}$ measurements in italic were made at the Centre de Recherches Pétrographiques et Géochimiques (CRPG-CNRS, France). Data were also acquired at the Danish Lithosphere Centre (DLC, Denmark) and the Geological Institute, University of Copenhagen (GI, Denmark). All basaltic chips and glasses were respectively leached in hot $6 \mathrm{~N} \mathrm{HCl}$ for 30 and 10 min at $120^{\circ} \mathrm{C}$, followed by brief ultrasonic leaching in Milli-Q water. For Pb analysis performed at DLC and CRPG, Pb was extracted according to the techniques of Baker et al. [2004] and Manhès et al. [1978], respectively. Blanks on a $100 \mathrm{mg}$ sample were less than 5-10 pg at DLC. They were less than $100 \mathrm{pg}$ on $300 \mathrm{mg}$ sample at CRPG. Blanks for Sr and Nd were found to be negligible. Double-spike (DS) Pb and Nd measurements performed on an MC-ICP-MS (AXIOM) at DLC follow the procedure of Baker et al. [2004] and Luais et al. [1997]. The ${ }^{207} \mathrm{~Pb}-{ }^{204} \mathrm{~Pb}$ double spike used is SBL7/4 and was prepared by Rex Taylor (University of Southampton, UK) and Laure Dosso (University of Brest, France). The average value for SRM981 obtained on repeated runs $(\mathrm{N}=11)$ is $16.9410 \pm 0.0032(2 \mathrm{sd})$ for ${ }^{206} \mathrm{~Pb} /{ }^{204} \mathrm{~Pb}, 15.4990 \pm 0.0033$ for ${ }^{207} \mathrm{~Pb} /{ }^{204} \mathrm{~Pb}$, and $36.7250 \pm 0.0085$ for ${ }^{208} \mathrm{~Pb} /{ }^{204} \mathrm{~Pb}$. The within-run uncertainty of the sample ED-DR57-1-1 is considered to represent the uncertainties on the Pb measurements. The Nd isotope measurements of standards are ${ }^{143} \mathrm{Nd} /{ }^{144} \mathrm{Nd}=0.512131 \pm 0.000023\left(\mathrm{~N}=29\right.$, Ames) and ${ }^{143} \mathrm{Nd} /{ }^{144} \mathrm{Nd}=0.511844 \pm 0.000026(\mathrm{~N}=10, \mathrm{La} \mathrm{Jolla})$. $\mathrm{Pb}$-isotope measurements acquired on the Isoprobe MC-ICPMS at CRPG were exponentially corrected for mass fractionation using the Tl-doping method [Rehkämper and Mezger, 2000; White et al., 2000] with a $\mathrm{Pb} / \mathrm{Tl}=10$ and a constant ${ }^{203} \mathrm{Tl} /{ }^{205} \mathrm{Tl}$ value of 2.38714 [Dunstan et al., 1980]. All $\mathrm{Pb}$ isotopic values have been normalized to the SRM981 composition of Todt et al. [1996]. The mean values for SRM981 $(\mathrm{N}=37)$ are 16.9319 \pm 0.0032 (2 sd) for ${ }^{206} \mathrm{~Pb} /{ }^{204} \mathrm{~Pb}, 15.4899 \pm 0.0038$ for ${ }^{207} \mathrm{~Pb} /{ }^{204} \mathrm{~Pb}$, and $36.7014 \pm 0.0118$ for ${ }^{208} \mathrm{~Pb} /{ }^{204} \mathrm{~Pb}$. For Sr isotopes acquired on a ThermoIonization Mass Spectrometer (TIMS) VG Sector 54-IT at the GI, the mean ${ }^{87} \mathrm{Sr} /{ }^{86} \mathrm{Sr}$ value of SRM987 standard is $0.710241 \pm 0.000028(\mathrm{~N}=4)$. For $\mathrm{Nd}$ and $\mathrm{Sr}$ isotope analyses, which were performed on a TIMS Finnigan MAT 262 at CRPG, the mean isotope standards for ${ }^{87} \mathrm{Sr}{ }^{86} \mathrm{Sr}$ and ${ }^{143} \mathrm{Nd} /{ }^{144} \mathrm{Nd}$ are $0.710164 \pm 28(\mathrm{~N}=15, \mathrm{SRM} 987)$ and $0.511096 \pm 26(\mathrm{~N}=16$, Johnson Matthey), respectively.
\end{abstract}

to the Madagascar plateau, which is considered as being the Late Cretaceous-Tertiary trace of the Marion hot spot on the African plate [Storey et al., 1995; Georgen et al., 2001].

\section{Results}

\section{1. $\mathrm{Pb}, \mathrm{Sr}$, and $\mathrm{Nd}$ Isotope Domains Within the SWIR Mantle}

[8] Samples were obtained during the EDUL (R/V Marion Dufresne, summer 1997) and SWIFT (R/V Marion Dufresne, winter 2001) cruises (Table 1). 113 dredge sites were selected along $\sim 4100 \mathrm{~km}$ of the SWIR between $\left(26.10^{\circ} \mathrm{S}, 68.73^{\circ} \mathrm{E}\right)$ and $\left(47.13^{\circ} \mathrm{S}, 32.48^{\circ} \mathrm{E}\right)$, along the neovolcanic zone (Figure 1). Geochemical data and analytical techniques are given in Table 1.

\subsubsection{General Trends}

[9] When plotted as a function of longitude (Figure 2), our new results combined with data from the literature for the SWIR provide an excellent overview of the general patterns of mantle heterogeneity along this ridge. Our data generally overlap those of earlier studies obtained without the double-spike (DS) technique for $\mathrm{Pb}$ isotopes [e.g., Mahoney et al., 1989, 1992], with the exception of some older ${ }^{207} \mathrm{~Pb} /{ }^{204} \mathrm{~Pb}$ data [e.g., Price et al., 1986]. The SWIR data cover a wide range of isotopic compositions, encompassing a substantial fraction of the range seen in MORB from all oceans (Table 1, Figure 2); ${ }^{206} \mathrm{~Pb} /{ }^{204} \mathrm{~Pb}$ varies from 16.583 to $18.426 ;{ }^{87} \mathrm{Sr} /{ }^{86} \mathrm{Sr}$ from 0.7027 to $0.7048 ;{ }^{143} \mathrm{Nd} /{ }^{144} \mathrm{Nd}$ from 0.5126 to 0.5132 . Most of the isotopic range over the studied region is represented by small-scale variations (Figure 2). For example, the isotopic heterogeneity of lavas located between 39 and $41^{\circ} \mathrm{E}$ (group D3) is remarkable, although it should be noted that the heterogeneity in $\mathrm{Nd}-\mathrm{Sr}-\mathrm{Pb}$ isotopes at the scale of an individual dredge is negligible (e.g., SW-DR13).

[10] To the east of the Gallieni FZ, the general shapes of the isotopic patterns for $\mathrm{Pb}$, and to $\mathrm{a}$ lesser extent for $\mathrm{Nd}$, correlate well with physical discontinuities, but not with variations in seafloor topography (Figures 1 and 2). There is generally no continuity in terms of $\mathrm{Nd}$ and $\mathrm{Pb}$-isotopic composition across the major ridge offsets $(>90 \mathrm{~km})$, while the $\mathrm{Sr}$ isotope profile is more uniform. In contrast, to the west of the Gallieni FZ, the patterns are different with lavas erupted in the vicinity of certain long-offset transforms (Eric Simpson and Indomed FZs) having lower ${ }^{143} \mathrm{Nd} /{ }^{144} \mathrm{Nd}$, higher ${ }^{87} \mathrm{Sr} /{ }^{86} \mathrm{Sr}$ and $\Delta 8 / 4$ (the offset of ${ }^{208} \mathrm{~Pb} /{ }^{204} \mathrm{~Pb}$ rela- 


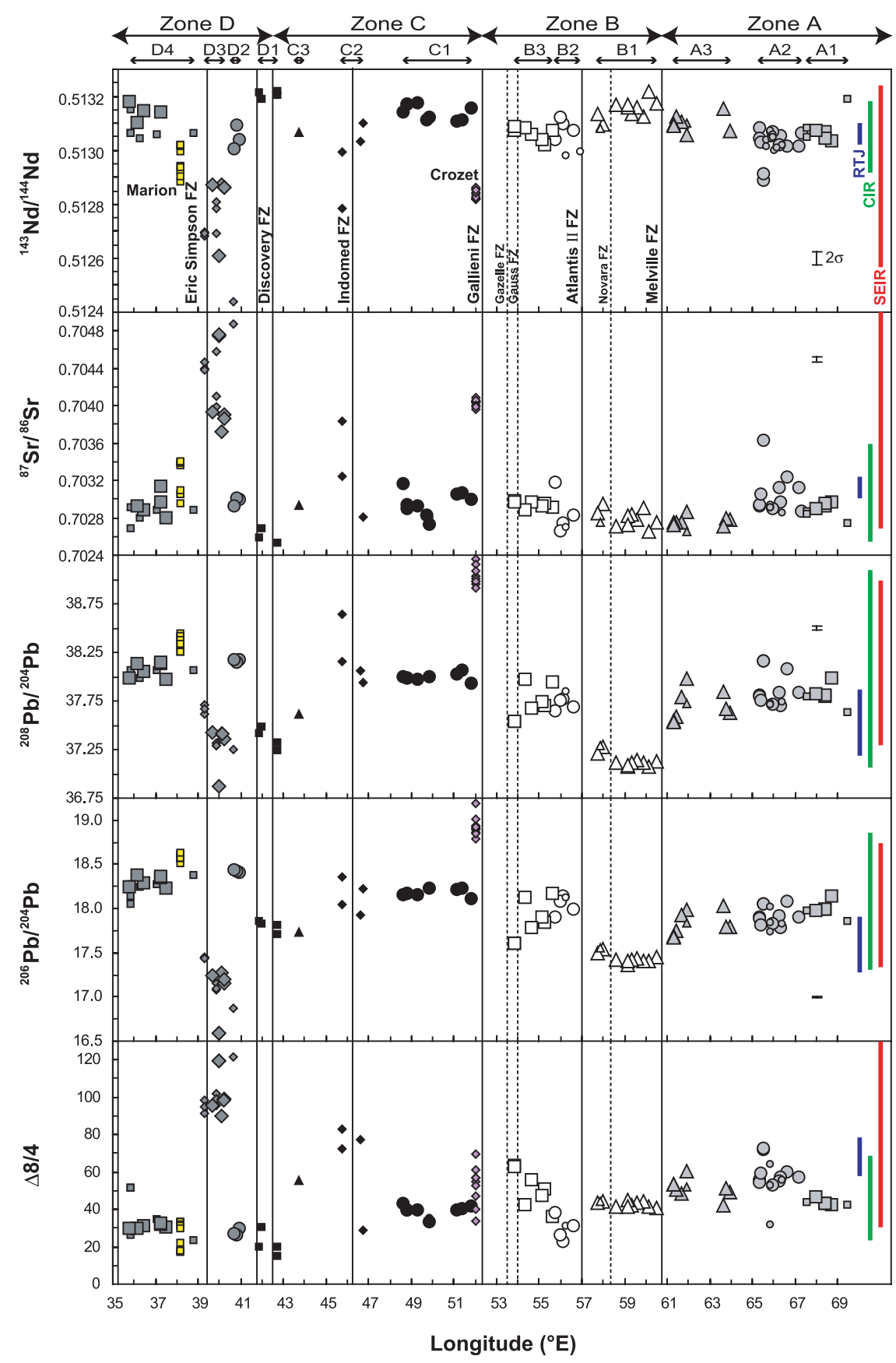

Figure 2. Along-axis profiles of isotope ratios from the SWIR lavas between $35^{\circ}$ and $69^{\circ} \mathrm{E}$. Data from this study are shown as big symbols along with $2 \sigma$ error bars. Previous data (small symbols) for the SWIR are from Dupré and Allègre [1983], Hamelin and Allègre [1985], Michard et al. [1986], Price et al. [1986], Mahoney et al. [1989, 1992], and Robinson et al. [2001]. Data for Marion and Crozet hot spots are from Hart [1988] and Mahoney et al. [1992, 1996]. Solid bars on right-hand side represent the range of isotope variations reported for Southeast Indian Ridge (SEIR), Central Indian Ridge and Carlsberg Ridge (CIR), and Rodrigues Triple Junction (RTJ) MORB [Hamelin et al., 1986; Michard et al., 1986; Price et al., 1986; Ito et al., 1987; Dosso et al., 1988; Klein et al., 1988; Mahoney et al., 1989, 1992; Pyle et al., 1992, 1995; Schiano et al., 1997; Rëkhamper and Hofmann, 1997; Kempton et al., 2002]. Data sets include both whole rock and glasses analyses. Locations of the major (continuous lines) and minor (dashed lines) Fracture Zones (FZ) are also shown. 
(a)

(b)

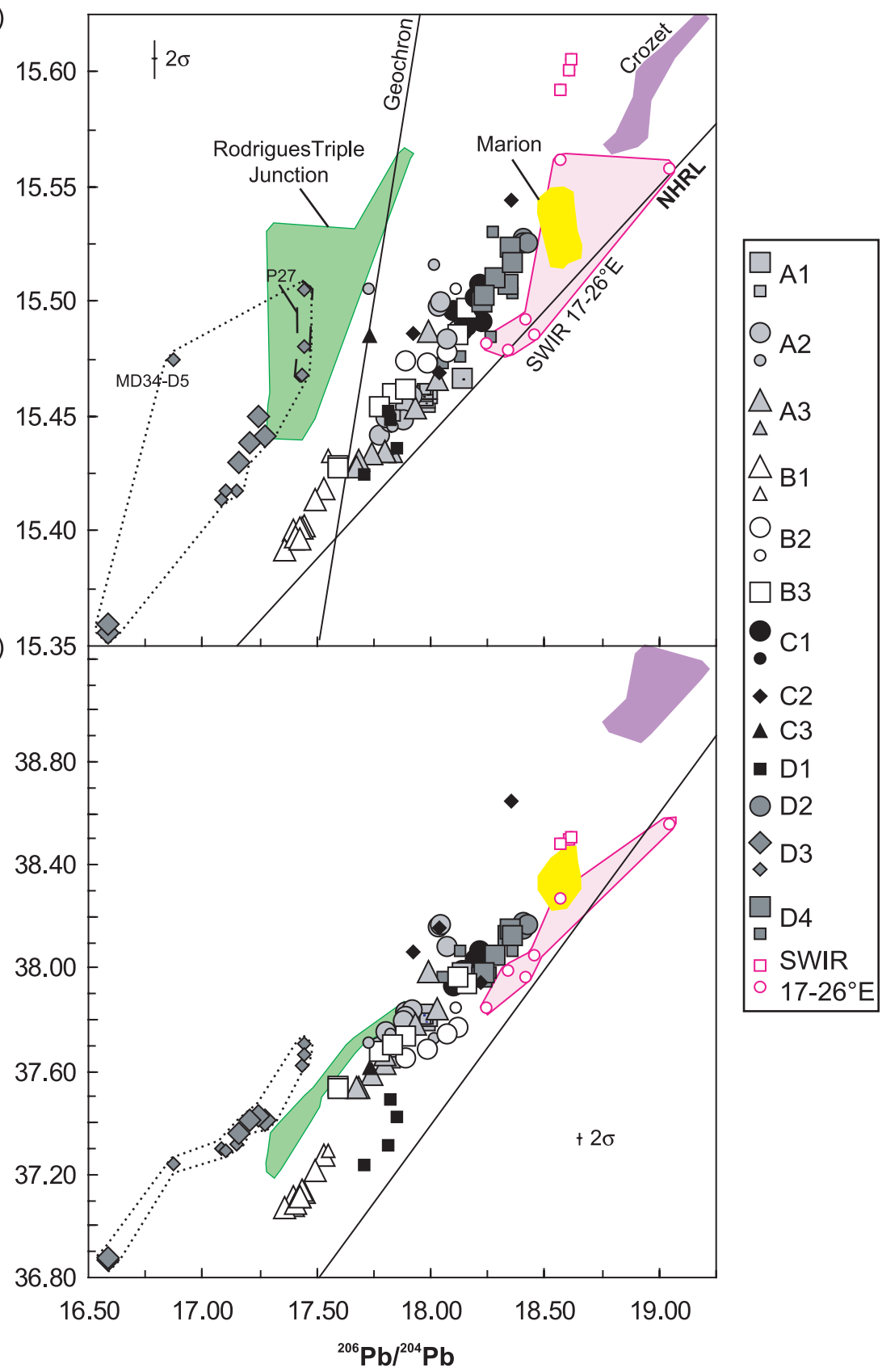

Figure 3. (a) ${ }^{207} \mathrm{~Pb} /{ }^{204} \mathrm{~Pb}$ and (b) ${ }^{208} \mathrm{~Pb} /{ }^{204} \mathrm{~Pb}$ against ${ }^{206} \mathrm{~Pb} /{ }^{204} \mathrm{~Pb}$ for SWIR lavas. Error bar is for data in this study. Big symbols represent SWIR MORBs from this study; small symbols are previous data. Data sources as in Figure 2. Shaded fields are for RTJ [Price et al., 1986; Michard et al., 1986; Ito et al., 1987], Marion [Hart, 1988; Mahoney et al., 1992], and Crozet [Mahoney et al., 1996] hot spots and SWIR MORB of south Atlantic affinity located between 17 and $26^{\circ} \mathrm{E}$ [Mahoney et al., 1992]. Within this latter area, three samples from the Du Toit FZ (pink squares) are isotopically anomalous and have been interpreted as being erratics from the South Sandwich Islands [Mahoney et al., 1992]. NHRL denotes the Northern Hemisphere Reference Line [Hart, 1984].

tive to the Northern Hemisphere reference line at a given ${ }^{206} \mathrm{~Pb} /{ }^{204} \mathrm{~Pb}$, as defined by [Hart, 1984]). In detail, the long and small length-scale variations of different isotopic ratios differ significantly from each other. For example, the high $\mathrm{Nd}$ and low $\mathrm{Pb}$ isotope values between 57 and $61^{\circ} \mathrm{E}$ are not correlated with $\mathrm{Sr}$-isotope variations.

[11] Over the area studied, the ridge may interact with either the Marion hot spot at $\sim 38^{\circ} \mathrm{E}$ or the 
(a) 15.53

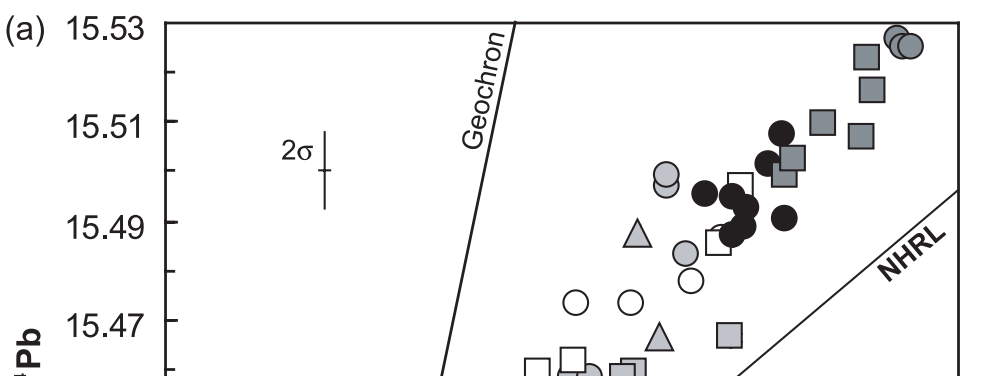

(b)
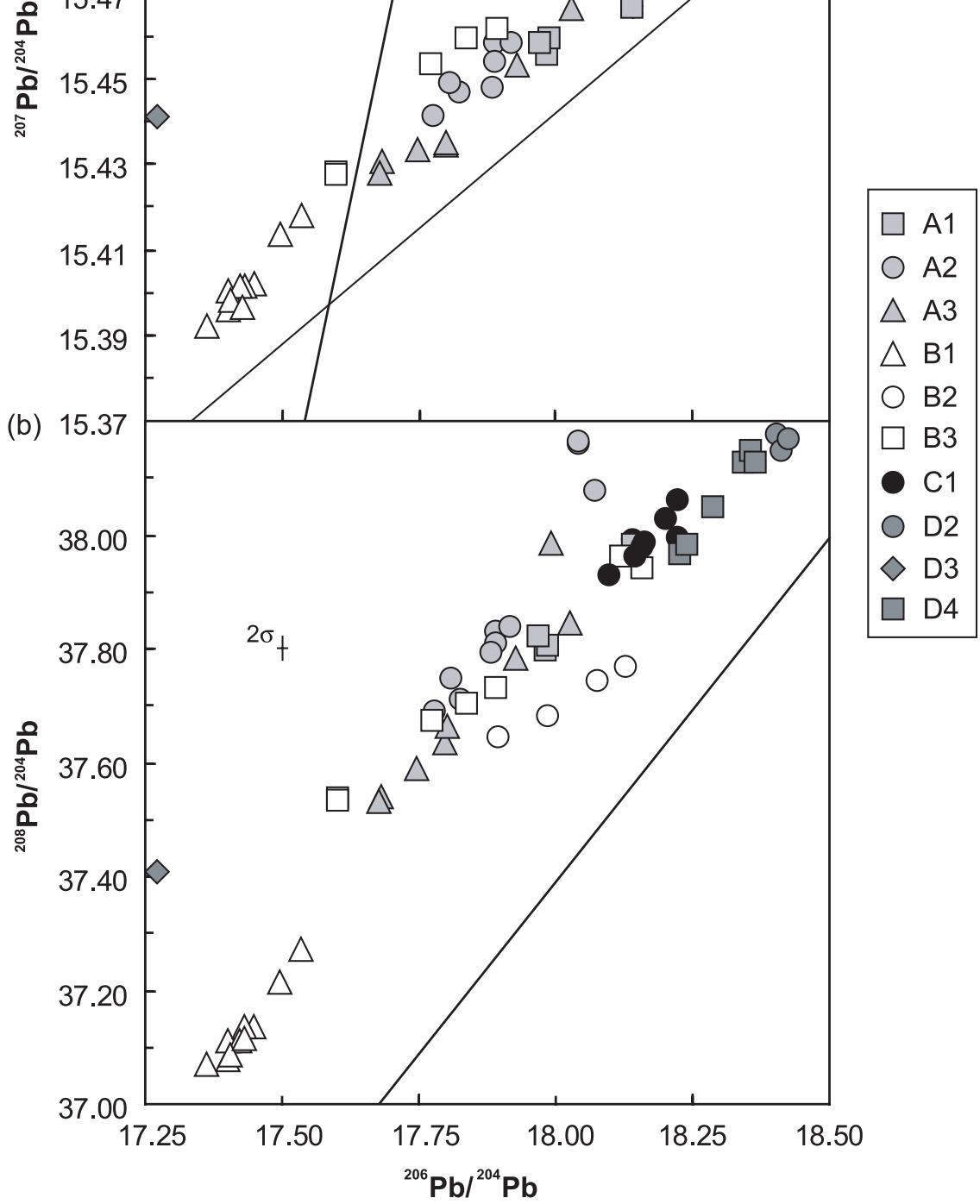

Figure 4. Close-up of the (a) ${ }^{207} \mathrm{~Pb} /{ }^{204} \mathrm{~Pb}$ and (b) ${ }^{208} \mathrm{~Pb} /{ }^{204} \mathrm{~Pb}$ against ${ }^{206} \mathrm{~Pb} /{ }^{204} \mathrm{~Pb}$ variations of SWIR lavas from this study.

Crozet hot spot at $\sim 52^{\circ} \mathrm{E}$, as suggested by gravimetric and bathymetric data [Georgen et al., 2001; Georgen and Lin, 2003]. Geographically, the 39$41^{\circ} \mathrm{E}$ section (groups D2-D3) roughly corresponds to the intersection of the ridge with the southern extension of the Madagascar Rise, which is the presumed post-80 Ma trace of the Marion hot spot on the African plate (Figures 1 and 2) [Storey et al., 1995]. Importantly, Marion hot spot lack Indian
Ocean isotope attributes and is characterized by extremely low values of $\Delta 8 / 4$ (16.8-32.9) [Hart, 1988; Mahoney et al., 1992]. It falls partially below the threshold between Pacific and Indian mantle $(\Delta 8 / 4<20$, whereas $\Delta 8 / 4$ is $>20$ for virtually all Indian MORB [Mahoney et al., 2002]). Another feature is that it has more MORB-like rather than ocean-island like isotope attributes (Figures 2, 3, 5, and 7). This particularity may account for the 


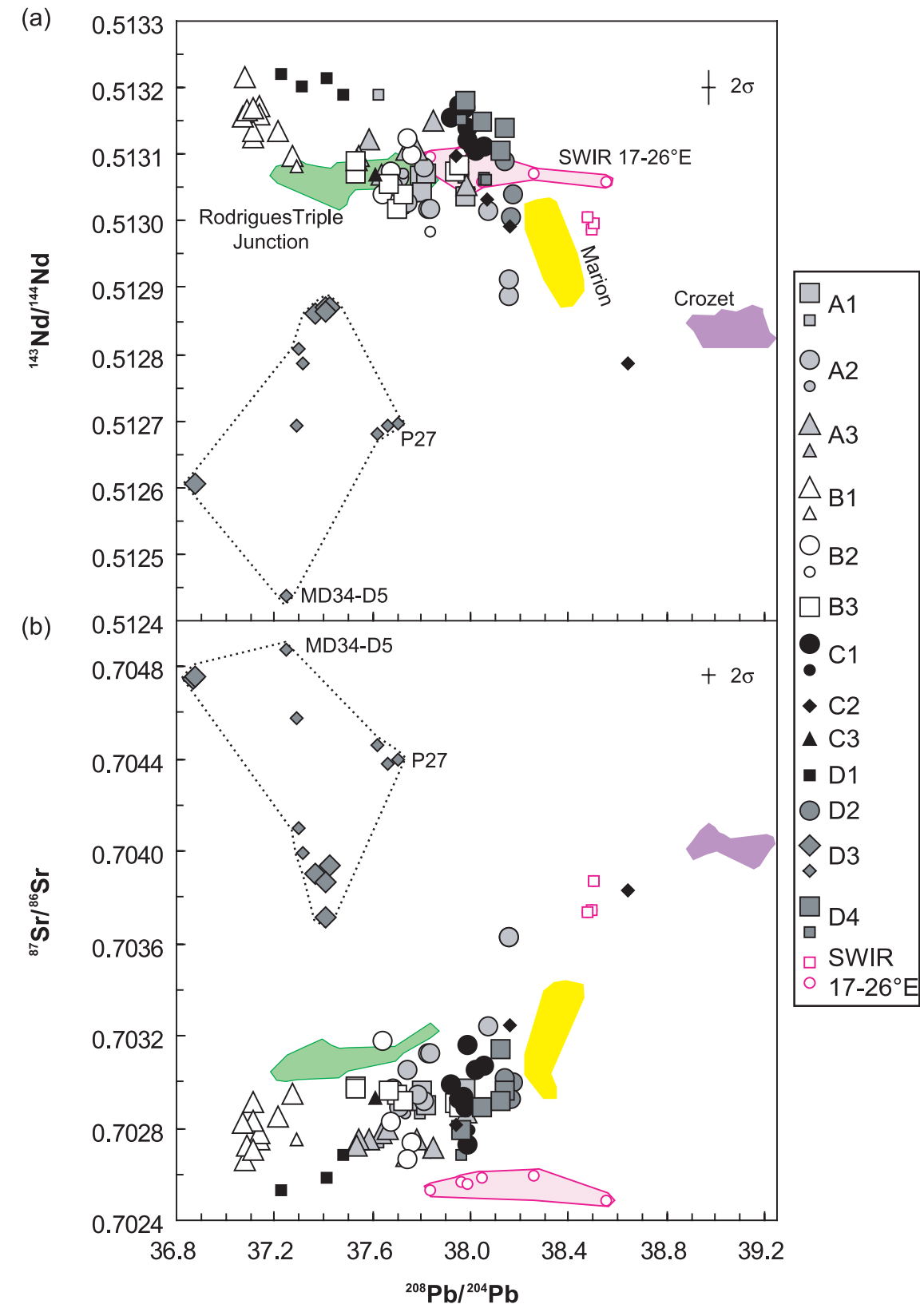

Figure 5. (a) ${ }^{143} \mathrm{Nd} /{ }^{144} \mathrm{Nd}$ and (b) ${ }^{87} \mathrm{Sr} /{ }^{86} \mathrm{Sr}$ against ${ }^{208} \mathrm{~Pb} /{ }^{204} \mathrm{~Pb}$ for SWIR lavas. Error bar is for data in this study. Big symbols represent SWIR MORBs from this study; small symbols are previous data. Data sources as in Figure 2.

absence of large-scale or small-scale gradients occurring in the vicinity of its potential on-axis location in the along-axis isotopic profiles (Figure 2). In contrast, the influence of Crozet hot spot should lead to increasing ${ }^{87} \mathrm{Sr} /{ }^{86} \mathrm{Sr},{ }^{206} \mathrm{~Pb} /{ }^{204} \mathrm{~Pb},{ }^{207} \mathrm{~Pb} /{ }^{204} \mathrm{~Pb}$, ${ }^{208} \mathrm{~Pb} /{ }^{204} \mathrm{~Pb}$ and decreasing ${ }^{143} \mathrm{Nd} /{ }^{144} \mathrm{Nd}$ in the vicinity of $\sim 52^{\circ} \mathrm{E}$. This is not observed (Figure 2) and the long ridge-hot spot conduit of more than $1000 \mathrm{~km}$ from the Crozet plateau to the SWIR (Figure 1) makes it unlikely that this hot spot influence would be present on the SWIR.
[12] For the SWIR, if the isotopic excursions near the Eric Simpson Fracture Zone (group D3) and Indomed FZ (group C2) are removed, systematic east-west variations are observed, as noted by Mahoney et al. [1992]. This is best expressed by the parameter $\Delta 8 / 4$, and to a lesser extent ${ }^{206} \mathrm{~Pb} /{ }^{204} \mathrm{~Pb}$ (Figure 2). To the west of the Gallieni $\mathrm{FZ}$, there is a general eastward increase in $\Delta 8 / 4$, but this increase is extremely irregular, resulting in large variations over small length scales such as between the Discovery FZ complex and Eric 
(a)

(b)

(a) 0.5133
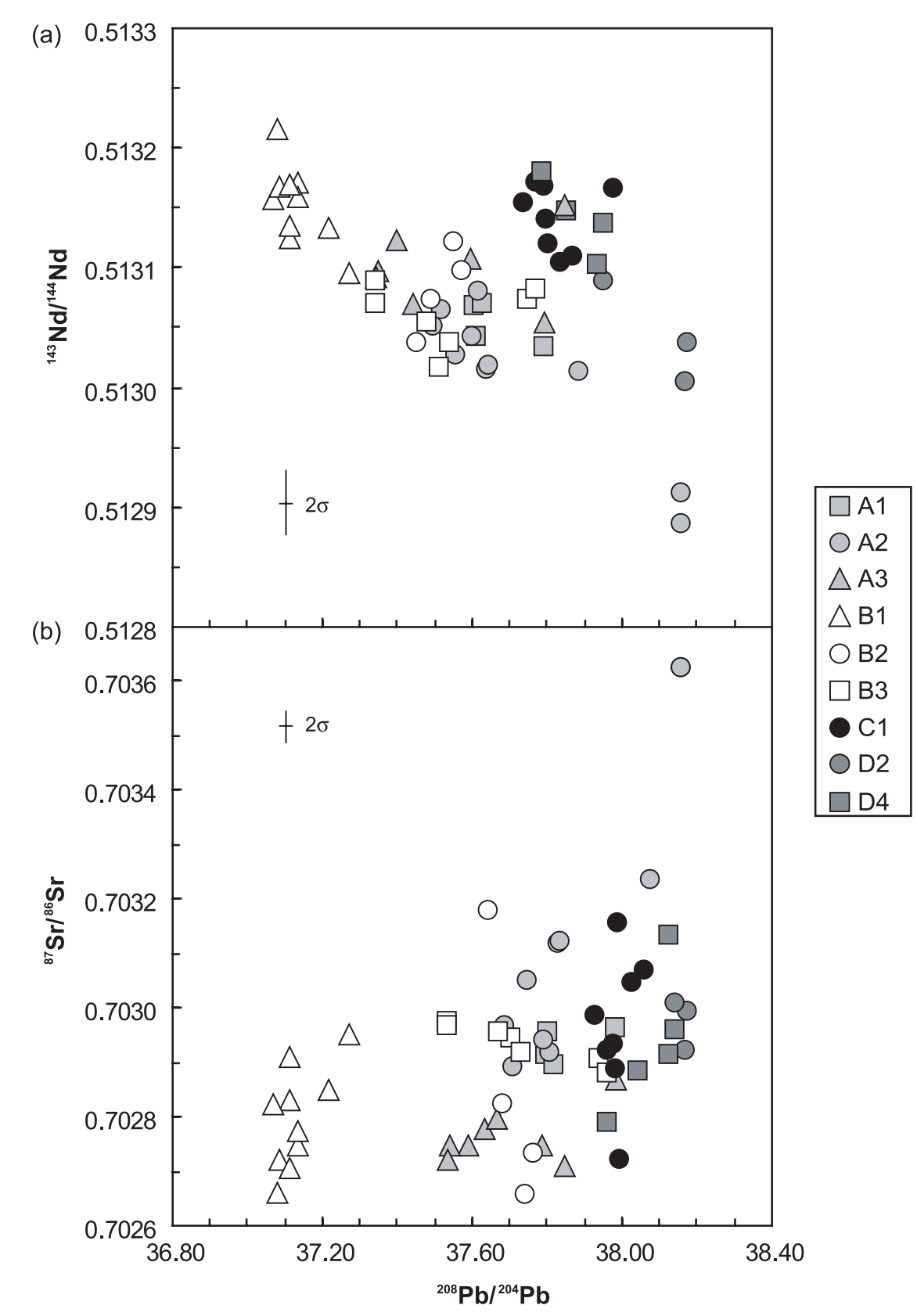

Figure 6. Close-up of the (a) ${ }^{143} \mathrm{Nd} /{ }^{144} \mathrm{Nd}$ and (b) ${ }^{87} \mathrm{Sr} /{ }^{86} \mathrm{Sr}$ against ${ }^{208} \mathrm{~Pb} /{ }^{204} \mathrm{~Pb}$ variations of SWIR lavas from this study.

Simpson FZ (25.7-119.7) and in the vicinity of the Indomed FZ (28.6-83.1). These anomalies, which are a dominant feature of the regional trend, appear to become less pronounced from the west to the east, at least to the east of the Indomed FZ.

\subsubsection{Isotopic Domains}

[13] As observed for other Indian mid-ocean ridges, correlations between ${ }^{208} \mathrm{~Pb} /{ }^{204} \mathrm{~Pb}$ and ${ }^{143} \mathrm{Nd} /{ }^{144} \mathrm{Nd},{ }^{208} \mathrm{~Pb} /{ }^{204} \mathrm{~Pb}$ and ${ }^{87} \mathrm{Sr} /{ }^{86} \mathrm{Sr}$ are poor $(\mathrm{r}=-0.46$ and 0.49 ), but are good between $\mathrm{Pb}$ isotope pairs $(r=0.95-0.98$, Table 2, Figures 3 and 4). In detail, the $\mathrm{Pb}$ correlations are composed of numerous groups or arrays defined by geographically related samples over a few degrees of longitude (Figures 3 and 4).

[14] On the basis of trace and major element characteristics of SWIR basaltic glasses, Meyzen et al. [2003] subdivided the area between 49 and $69^{\circ} \mathrm{E}$ into two main provinces (e.g., zones $\mathrm{A}$ and B) separated by the Melville FZ. However, in zones $\mathrm{A}$ and $\mathrm{B}$, six different isotopic domains 


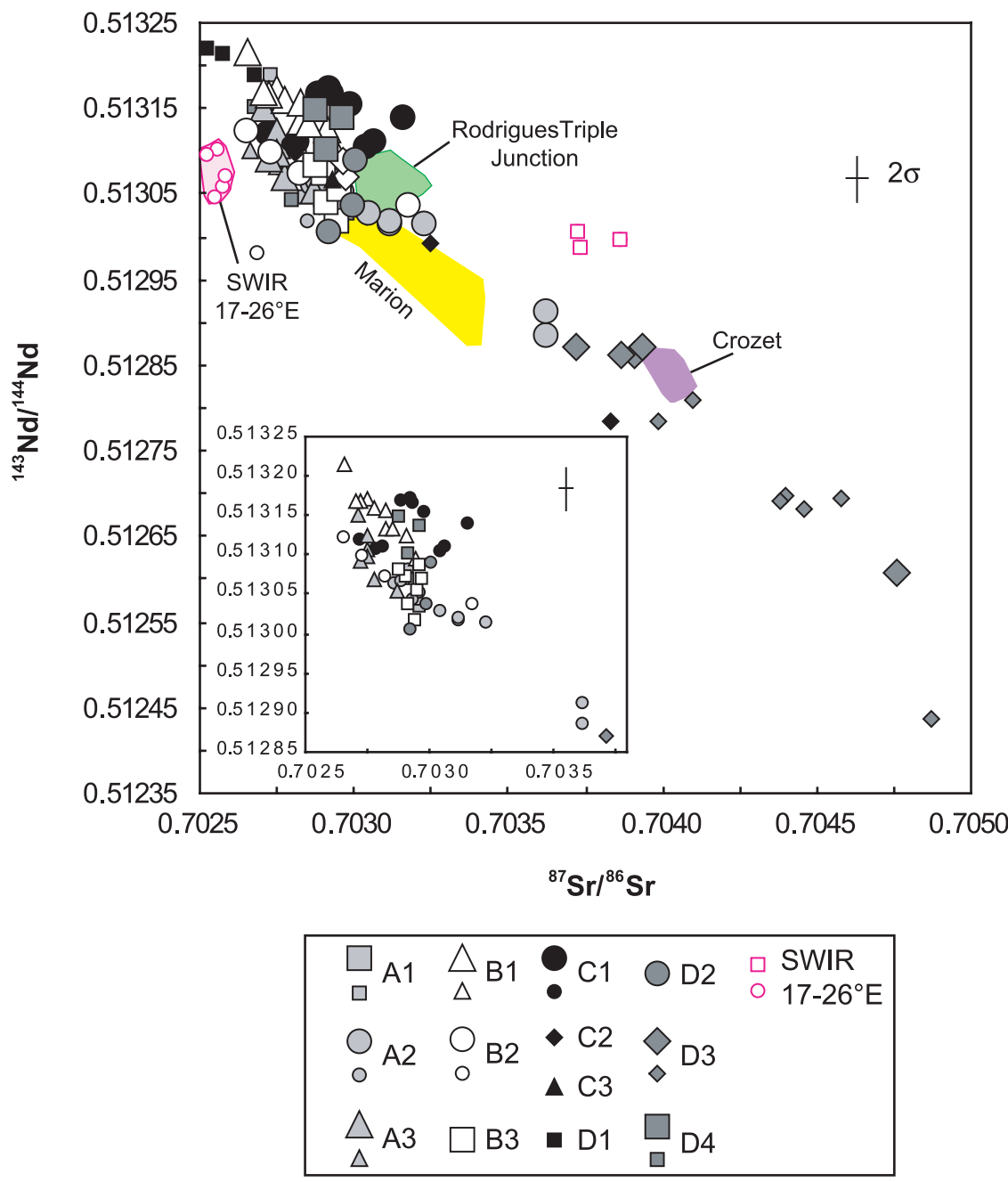

Figure 7. ${ }^{143} \mathrm{Nd} /{ }^{144} \mathrm{Nd}$ against ${ }^{87} \mathrm{Sr} /{ }^{86} \mathrm{Sr}$ for SWIR lavas. Big symbols represent SWIR MORBs from this study; small symbols are previous data. Data sources as in Figure 2. Inset shows our SWIR data.

(A1-A3 and B1-B3) can be defined (Figures $1 \mathrm{~b}-$ 4). Within zone $A$, for the same range of ${ }^{206} \mathrm{~Pb} /{ }^{204} \mathrm{~Pb}, \mathrm{MORB}$ from the section A2 are characterized by higher ${ }^{208} \mathrm{~Pb} /{ }^{204} \mathrm{~Pb},{ }^{87} \mathrm{Sr} /{ }^{86} \mathrm{Sr}$ and lower ${ }^{143} \mathrm{Nd} /{ }^{144} \mathrm{Nd}$ than those from the adjacent sections A1 and A3 (Figures 3-6), with a broad negative correlation between ${ }^{87} \mathrm{Sr} /{ }^{86} \mathrm{Sr}$ and ${ }^{143} \mathrm{Nd} /{ }^{44} \mathrm{Nd}$
(Figure 7). Samples from the section A1, closest to the RTJ, have lower ${ }^{207} \mathrm{~Pb} /{ }^{204} \mathrm{~Pb},{ }^{208} \mathrm{~Pb} /{ }^{204} \mathrm{~Pb}$ and ${ }^{87} \mathrm{Sr} /{ }^{86} \mathrm{Sr}$ ratios than the fields defined by the RTJ basalts (Figures 3-5).

[15] Within zone $\mathrm{B}$, the section $\mathrm{B} 1$, bounded by the Melville FZ and Atlantis $\Pi$ FZ, is remarkable

Table 2. Correlation of Isotope Ratios in SWIR MORB $(\mathrm{N}=56)^{\mathrm{a}}$

\begin{tabular}{lccccc}
\hline & ${ }^{206} \mathrm{~Pb} /{ }^{204} \mathrm{~Pb}$ & ${ }^{207} \mathrm{~Pb} /{ }^{204} \mathrm{~Pb}$ & ${ }^{208} \mathrm{~Pb} /{ }^{204} \mathrm{~Pb}$ & ${ }^{87} \mathrm{Sr} /{ }^{86} \mathrm{Sr}$ & ${ }^{143} \mathrm{Nd} /{ }^{144} \mathrm{Nd}$ \\
\hline${ }^{206} \mathrm{~Pb} /{ }^{204} \mathrm{~Pb}$ & 1 & 0.977 & 0.951 & 0.307 & -0.269 \\
${ }^{207} \mathrm{~Pb} /{ }^{204} \mathrm{~Pb}$ & 0.977 & 1 & 0.949 & 0.419 & -0.322 \\
${ }^{208} \mathrm{~Pb} /{ }^{204} \mathrm{~Pb}$ & 0.951 & 0.949 & 1 & 0.494 & -0.461 \\
${ }^{87} \mathrm{Sr} /{ }^{86} \mathrm{Sr}$ & 0.307 & 0.419 & 0.494 & 1 & -0.726 \\
${ }^{143} \mathrm{Nd} /{ }^{144} \mathrm{Nd}$ & -0.269 & -0.322 & -0.461 & -0.726 & 1 \\
\hline
\end{tabular}

\footnotetext{
${ }^{\mathrm{a}}$ Excluding those of the $39-41^{\circ} \mathrm{E}$ section, which trend obliquely compared to the main SWIR population. Only
} samples where all the ratios were available have been used. 
in its very low ${ }^{206} \mathrm{~Pb} /{ }^{204} \mathrm{~Pb}$ (down to 17.363 ), and low ${ }^{207} \mathrm{~Pb} /{ }^{204} \mathrm{~Pb},{ }^{208} \mathrm{~Pb} /{ }^{204} \mathrm{~Pb},{ }^{87} \mathrm{Sr} /{ }^{86} \mathrm{Sr}$ and high ${ }^{143} \mathrm{Nd} /{ }^{144} \mathrm{Nd}$ (Figures $2-7$ ). These peculiar isotopic features have also been reported for gabbros drilled from the eastern wall of the Atlantis $\Pi$ Fracture Zone [Kempton et al., 1991; Holm, 2002], which exhibit even lower ${ }^{206} \mathrm{~Pb} /{ }^{204} \mathrm{~Pb}$ (down to 16.764) and for peridotites from the Atlantis $\Pi$ transform valley having ${ }^{143} \mathrm{Nd} /{ }^{144} \mathrm{Nd}$ up to 0.513409 [Salters and Dick, 2002]. Similar isotopic attributes also characterize some lavas from the Carlsberg ridge located at $9.8^{\circ} \mathrm{N}$ near the Owen FZ [Dupré and Allègre, 1983; Mahoney et al., 1989]. On the SWIR, this ultra-depleted and homogeneous signature occurs over $\sim 400 \mathrm{~km}$. The two other sections of zone $\mathrm{B}$ are more radiogenic in $\mathrm{Pb}$, displaying higher ${ }^{206} \mathrm{~Pb} /{ }^{204} \mathrm{~Pb}$, ${ }^{208} \mathrm{~Pb} /{ }^{204} \mathrm{~Pb}$ and ${ }^{207} \mathrm{~Pb} /{ }^{204} \mathrm{~Pb}$, and lower ${ }^{143} \mathrm{Nd} /{ }^{144} \mathrm{Nd}$ than section B1 (Figures 3-6). While these sections form two distinct arrays in ${ }^{208} \mathrm{~Pb} /{ }^{204} \mathrm{~Pb}$ versus ${ }^{206} \mathrm{~Pb} /{ }^{204} \mathrm{~Pb}$, they form a single array in ${ }^{207} \mathrm{~Pb} /{ }^{204} \mathrm{~Pb}$ versus ${ }^{206} \mathrm{~Pb} /{ }^{204} \mathrm{~Pb}$ (Figure 4). These lavas are also characterized by higher ${ }^{207} \mathrm{~Pb} /{ }^{204} \mathrm{~Pb}$ for a given ${ }^{206} \mathrm{~Pb} /{ }^{204} \mathrm{~Pb}$ than most of the lavas located to the east of the Melville FZ (Figure 4a). Consideration of ${ }^{87} \mathrm{Sr} /{ }^{86} \mathrm{Sr}$ as a function of ${ }^{208} \mathrm{~Pb} /{ }^{204} \mathrm{~Pb}$, shows that most lavas from section B2 display lower ${ }^{87} \mathrm{Sr} /{ }^{86} \mathrm{Sr}$ than those from section B3 (Figure 6). In ${ }^{143} \mathrm{Nd} /{ }^{144} \mathrm{Nd}$ versus ${ }^{87} \mathrm{Sr} /{ }^{86} \mathrm{Sr}$, samples from sections $\mathrm{B} 2$ and $\mathrm{B} 3$ fall within the broad negative correlation defined by lavas from zone A (Figure 7).

[16] Within zone $\mathrm{C}$, defined as extending from the Gallieni FZ to Discovery $\Pi$ FZ, two isotopic domains $(\mathrm{C} 1-\mathrm{C} 2)$ are clearly identified (Figures $1 \mathrm{~b}-$ 3 ). A third domain (C3) may exist, but is represented by only one lava from Hamelin and Allègre [1985]. Each group $(\mathrm{C} 1-\mathrm{C} 2)$ roughly defines a linear array in ${ }^{208} \mathrm{~Pb} /{ }^{204} \mathrm{~Pb}$ versus ${ }^{206} \mathrm{~Pb} /{ }^{204} \mathrm{~Pb}$, with the section $\mathrm{C} 2$ generally having substantially higher ${ }^{208} \mathrm{~Pb} /{ }^{204} \mathrm{~Pb}$ for a given ${ }^{206} \mathrm{~Pb} /{ }^{204} \mathrm{~Pb}$ than most samples from the area studied (Figure 3) [Mahoney et al., 1992]. For a given ${ }^{208} \mathrm{~Pb} /{ }^{204} \mathrm{~Pb}$, samples from the section $\mathrm{C} 1$ have higher ${ }^{143} \mathrm{Nd} /{ }^{144} \mathrm{Nd}$, but similar ${ }^{87} \mathrm{Sr} /{ }^{86} \mathrm{Sr}$ compared to those from the section $\mathrm{C} 2$ and those further to the east (Figure 5).

[17] Within zone D, defined as extending from the Discovery FZ complex to the Prince Edward FZ, four isotopic domains are identified (D1-D4) (Figures 1b-2). All samples from the group D1, bounded by the Discovery FZ complex, display north/central Atlantic or Pacific affinity in $\mathrm{Pb}$ and
$\mathrm{Nd}$ isotopes [Mahoney et al., 1992, Figures 2a3]. Samples from section D1 have the highest ${ }^{143} \mathrm{Nd} /{ }^{144} \mathrm{Nd}$, the lowest ${ }^{87} \mathrm{Sr} /{ }^{86} \mathrm{Sr}$ and $\Delta 8 / 4$ reported to date for the whole SWIR (Figure 2). Our new sampling for the $39-41^{\circ} \mathrm{E}$ section, extending from the Eric Simpson to the Discovery $\mathrm{FZs}$, offers new insights into the definition of the remarkable isotopic anomaly previously reported by Mahoney et al. [1992]. Samples from this section have been shown to be exceptional in possessing very low ${ }^{206} \mathrm{~Pb} /{ }^{204} \mathrm{~Pb}(16.877-$ $17.449),{ }^{143} \mathrm{Nd} /{ }^{144} \mathrm{Nd}(0.5124-0.5128)$, ${ }^{176} \mathrm{Hf} /{ }^{177} \mathrm{Hf}(0.282768)$ and high ${ }^{87} \mathrm{Sr} /{ }^{86} \mathrm{Sr}$ $(0.7040-0.7049),{ }^{207} \mathrm{~Pb} /{ }^{204} \mathrm{~Pb}(15.414-15.505)$, ${ }^{208} \mathrm{~Pb} /{ }^{204} \mathrm{~Pb} \quad(37.245-37.706),{ }^{187} \mathrm{Os} /{ }^{188} \mathrm{Os}$ (0.3349) relative to other Indian MORB, but have a typical N-MORB value of ${ }^{3} \mathrm{He} /{ }^{4} \mathrm{He}$ (7.53) [Dupré and Allègre, 1983; Mahoney et al., 1989, 1992; Chauvel and Blichert-Toft, 2001; Escrig et al., 2004]. This combination of values is unique to date among oceanic island, seamount and ridge basalts worldwide. Due to their extreme Indian Ocean isotope attributes (Figures 8 and 9), lavas from this section have been considered to provide one of the best examples to date of the component responsible for the isotopic difference between most Indian MORB and their Pacific/ north Atlantic counterparts [Mahoney et al., 1992]. Another example of this extreme Indian Ocean anomaly is in lavas from the Aphanasy-Nikitin Rise in the eastern Indian Ocean (Figures 8 and 9), which possibly represent the late Cretaceous product of the Crozet hot spot [Mahoney et al., 1996]. However, this signature does not show any clear affinity with recent products from the Crozet hot spot, and has thus been ascribed either to a temporal change of its isotopic composition or to the presence of continental material in the source of the Crozet plume [Mahoney et al., 1996]. These two unradiogenic ${ }^{206} \mathrm{~Pb} /{ }^{204} \mathrm{~Pb}$ signatures are confined to restricted geographic regions of the Indian Ocean.

[18] Our data for the $39-41^{\circ} \mathrm{E}$ section extend the previously described isotopic ranges to the lowest ${ }^{206} \mathrm{~Pb} /{ }^{204} \mathrm{~Pb}$ value (down to 16.58 ) yet found among oceanic mantle derived rocks (e.g., SWDR13). More importantly, our new sampling shows that the $39-41^{\circ} \mathrm{E}$ section includes two discrete isotopic domains, identified as D2 and D3 in the figures. The most prominent isotopic anomaly itself (D3) is almost entirely restricted to the segment adjacent to Eric Simpson FZ, where $\Delta 8 / 4$ are as high as 120 (Figure 2). This anomaly is distinct and does not follow the general trend 


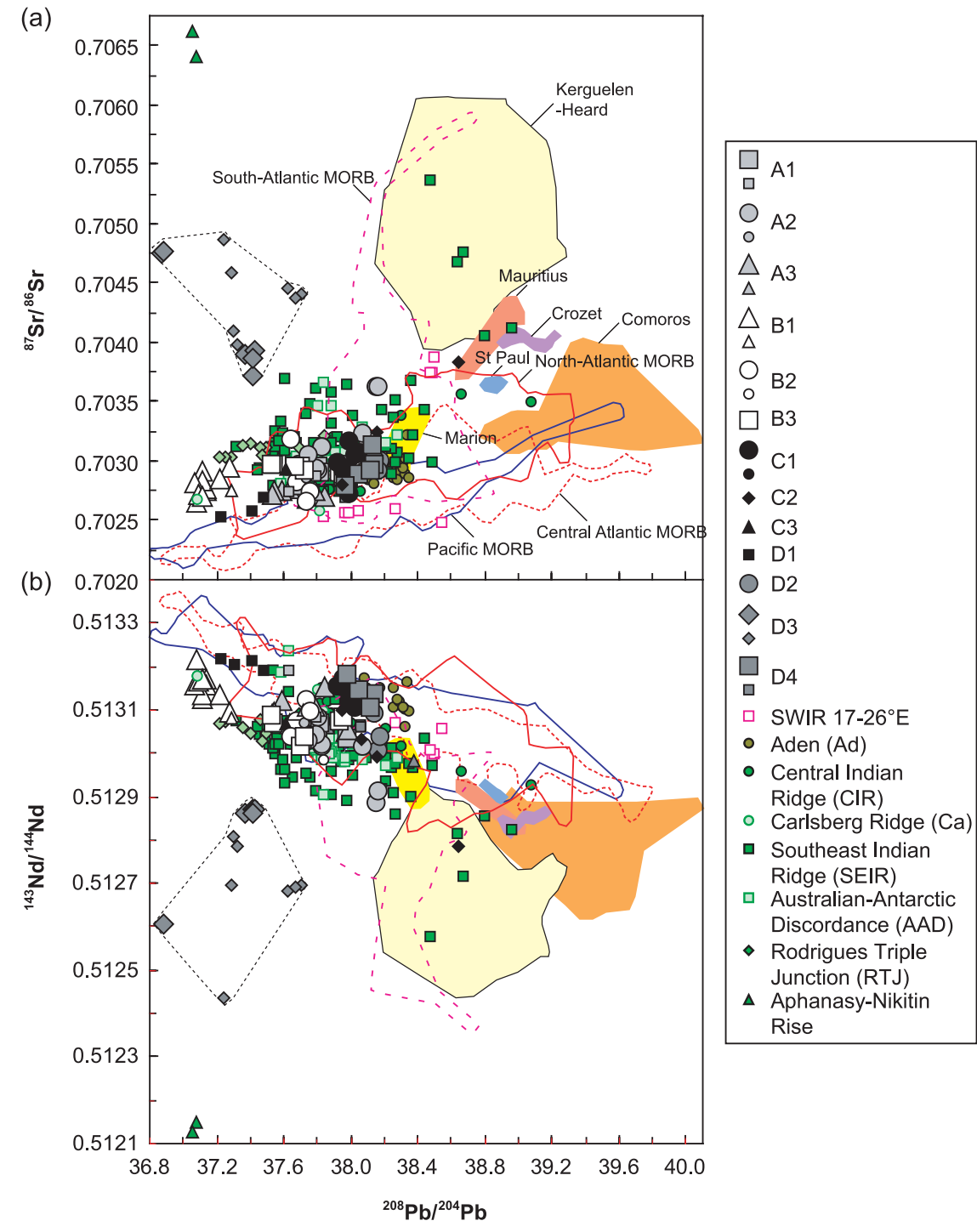

Figure 8. SWIR lavas (a) ${ }^{87} \mathrm{Sr} /{ }^{86} \mathrm{Sr}$ and (b) ${ }^{143} \mathrm{Nd} /{ }^{144} \mathrm{Nd}$ against ${ }^{208} \mathrm{~Pb} /{ }^{204} \mathrm{~Pb}$ variations compared to north Atlantic, central Atlantic (defined as extending from the Kane to Moore Fracture Zones), south Atlantic and Pacific MORB, Indian Oceanic Island Basalts, and other Indian Ocean spreading centers. Fields have been drawn from data sets including both whole rock and glasses analyses. See Auxiliary Material for references used. ${ }^{1}$ Data sources for previous SWIR lavas (small symbols) as in Figure 2.

defined by the main SWIR population (Figures 36). The lavas from section D3 are extremely heterogeneous in all isotopic systems, but can themselves be ascribed to two groups (Figure 5). Samples P27 and MD34-D5 from Mahoney et al. [1992] are characterized by lower ${ }^{143} \mathrm{Nd} /{ }^{144} \mathrm{Nd}$, higher ${ }^{87} \mathrm{Sr} /{ }^{86} \mathrm{Sr}$ for a given ${ }^{208} \mathrm{~Pb} /{ }^{204} \mathrm{~Pb}$ and higher ${ }^{208} \mathrm{~Pb} /{ }^{204} \mathrm{~Pb},{ }^{207} \mathrm{~Pb} /{ }^{204} \mathrm{~Pb}$ for a given ${ }^{206} \mathrm{~Pb} /{ }^{204} \mathrm{~Pb}$ than samples from our dredges 10,13,14, 15, and 16, and from the dredge P28 from Mahoney et al. [1992]. Interestingly, LeRoex et al. [1989] also noted the existence of two trends, corresponding to dredges P27 and P28, defined on the basis of trace and major element characteristics. In contrast, samples from the section D2, adjacent to the Discovery FZ, are uniform and are the most radiogenic in ${ }^{206} \mathrm{~Pb} /{ }^{204} \mathrm{~Pb}(18.407-18.426)$ of the studied area (Figures 3-7). They are displaced toward lower ${ }^{208} \mathrm{~Pb} /{ }^{204} \mathrm{~Pb}$ for a given ${ }^{206} \mathrm{~Pb} /{ }^{204} \mathrm{~Pb}$ relative to other sections with the exception of the group B2 (Figures $3 b-4 b$ ). In all isotopic diagrams, these lavas fall near or slightly overlap the field defined by the Marion hot spot and are similar to lavas from the section $36-39^{\circ} \mathrm{E}$ (D4) extending from the Eric Simpson FZ to the Prince Edward FZ.

${ }^{1}$ Auxiliary material is available at $\mathrm{ftp} / / / \mathrm{ftp}$.agu.org/apend/gc/ 2005GC000979. 
(a)

(b)

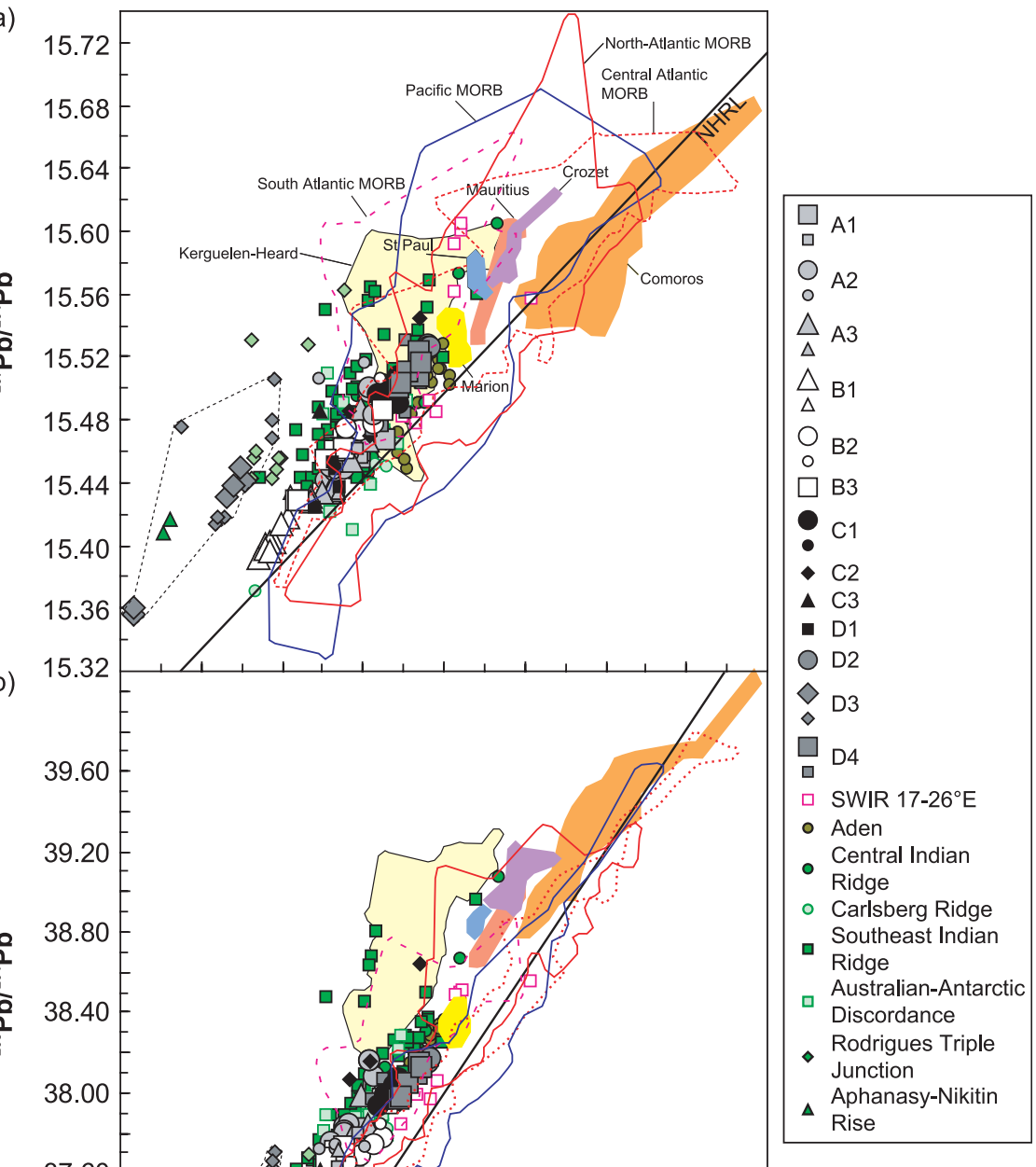

Figure 9. SWIR lavas (a) ${ }^{207} \mathrm{~Pb} /{ }^{204} \mathrm{~Pb}$ and (b) ${ }^{208} \mathrm{~Pb} /{ }^{204} \mathrm{~Pb}$ against ${ }^{206} \mathrm{~Pb} /{ }^{204} \mathrm{~Pb}$ variations compared to north Atlantic, central Atlantic, south Atlantic, and Pacific MORB, Indian Oceanic Island Basalts, and other Indian Ocean spreading centers. Fields have been drawn from data sets including both whole rock and glasses analyses. See Auxiliary Material for references used. NHRL denotes the Northern Hemisphere Reference Line [Hart, 1984]. Data sources for previous SWIR lavas (small symbols) as in Figure 2.

\subsection{SWIR Lavas Compared to Indian, North Atlantic, and Pacific MORB Arrays}

[19] In general, Indian ocean MORB define broadly positive ${ }^{87} \mathrm{Sr} /{ }^{86} \mathrm{Sr}-{ }^{206} \mathrm{~Pb} /{ }^{204} \mathrm{~Pb}$, negative ${ }^{143} \mathrm{Nd} /{ }^{144} \mathrm{Nd}-{ }^{206} \mathrm{~Pb} /{ }^{204} \mathrm{~Pb}$ and positive ${ }^{208} \mathrm{~Pb} /{ }^{204} \mathrm{~Pb}-{ }^{206} \mathrm{~Pb}-{ }^{204} \mathrm{~Pb}$ correlations, that are parallel to, but offset from the trend defined by most lavas from the Pacific and Central Atlantic Oceans (Figures 8 and 9). The largest isotopic difference is observed for Indian MORB with ${ }^{206} \mathrm{~Pb} /{ }^{204} \mathrm{~Pb}<18$. In contrast, they overlap with north and south Atlantic MORB (Figures 8 and 9).

[20] In a plot of ${ }^{87} \mathrm{Sr} /{ }^{86} \mathrm{Sr}$ as a function of ${ }^{208} \mathrm{~Pb} /{ }^{204} \mathrm{~Pb}$ (Figure $8 \mathrm{a}$ ), most lavas from the area studied overlap the north Atlantic and other Indian MORB fields, except those of the RTJ and Aphanasy-Nikitin Rise located to the southern end of the non-seismic $85^{\circ}$ East Ridge [Michard et al., 1986; 
Price et al., 1986; Mahoney et al., 1996]. The 57$61^{\circ} \mathrm{E}$ SWIR section (B1) extends the general Indian MORB array to lower ${ }^{87} \mathrm{Sr} /{ }^{86} \mathrm{Sr}$ and higher ${ }^{143} \mathrm{Nd} /{ }^{144} \mathrm{Nd}$ for a given ${ }^{208} \mathrm{~Pb} /{ }^{204} \mathrm{~Pb}$, as does one sample from the Carlsberg Ridge located near the Owen FZ (Figure 8) [Dupré and Allègre, 1983; Mahoney et al., 1989]. The $39-41^{\circ} \mathrm{E}$ section (D3) forms a vertical trend toward high ${ }^{87} \mathrm{Sr} /{ }^{86} \mathrm{Sr}$ oblique to the general Indian Ocean population. The same systematic behavior is observed in Nd relative to $\mathrm{Pb}$ (Figure 8b), where SWIR samples fall in the general array defined by other Indian ridges trending toward either Kerguelen type Ocean Island Basalt (OIB) or toward Mauritius, St Paul and Crozet OIB. When considered within the same range of ${ }^{208} \mathrm{~Pb} /{ }^{204} \mathrm{~Pb}$ (Figure $8 \mathrm{~b}$ ), most samples from the easternmost SWIR, located to the east of the Gallieni Fracture Zone, from the AustralianAntarctic Discordance, from the RTJ and from the Southeast Indian Ridge are characterized by lower ${ }^{143} \mathrm{Nd} /{ }^{144} \mathrm{Nd}$ than those from the Carlsberg Ridge, Central Indian Ridge, Gulf of Aden and those from the SWIR between $52^{\circ}$ and $26^{\circ} \mathrm{E}$ (with the exception of the groups D3 and C2). All lavas from the Discovery FZ complex (D1), from sections C1 and D4 lie within or closely adjacent to the Pacific/ Atlantic arrays.

[21] Overall, the majority of SWIR lavas are consistently higher than Pacific/Central Atlantic MORB in ${ }^{208} \mathrm{~Pb} /{ }^{204} \mathrm{~Pb}$ at a given ${ }^{206} \mathrm{~Pb} /{ }^{204} \mathrm{~Pb}$ (Figure 9). Most samples located to the west of the Discovery Fracture zone, except those from the section D3, have lower ${ }^{208} \mathrm{~Pb} /{ }^{204} \mathrm{~Pb}$ when compared to other Indian MORB with similar ${ }^{206} \mathrm{~Pb} /{ }^{204} \mathrm{~Pb}$ values. To the east, some samples from section B2 slightly extend the Indian field toward lower ${ }^{208} \mathrm{~Pb} /{ }^{204} \mathrm{~Pb}$ for a given ${ }^{206} \mathrm{~Pb} /{ }^{204} \mathrm{~Pb}$. All these samples overlap the north Atlantic, central Atlantic, and Pacific fields.

[22] As would be expected, most of our samples overlap isotope values of other Indian ridges in terms of ${ }^{207} \mathrm{~Pb} /{ }^{204} \mathrm{~Pb}$ as a function of ${ }^{206} \mathrm{~Pb} /{ }^{204} \mathrm{~Pb}$ (Figure 9). Lavas from the zones B1 and D3 are highly unradiogenic in ${ }^{206} \mathrm{~Pb} /{ }^{204} \mathrm{~Pb}$, as are most samples from the RTJ, from the Aphanasy-Nikitin Rise and one sample from the Carlsberg ridge.

\section{Discussion}

[23] The SWIR represents an isotopic transition between typical Indian Ocean-type compositions to the east and Atlantic like ones west of $26^{\circ} \mathrm{E}$ [Mahoney et al., 1992]. In the section studied here, east of $35^{\circ} \mathrm{E}$, lavas are indeed characterized by the same general features for $\mathrm{Sr}-\mathrm{Nd}-\mathrm{Pb}$ isotopes as Indian MORB. However, in detail, some lavas studied define distinct non-radiogenic end-members in ${ }^{206} \mathrm{~Pb} /{ }^{204} \mathrm{~Pb}$ strongly differing in terms of ${ }^{143} \mathrm{Nd} /{ }^{144} \mathrm{Nd},{ }^{87} \mathrm{Sr} /{ }^{86} \mathrm{Sr},{ }^{207} \mathrm{~Pb} /{ }^{204} \mathrm{~Pb}$ and ${ }^{208} \mathrm{~Pb} /{ }^{204} \mathrm{~Pb}$ (groups B1 and D3), which extend the field for Indian MORB (Figures 8 and 9).

[24] Among its other peculiar features, the SWIR is isotopically more heterogeneous over the $\sim 4100 \mathrm{~km}$ studied here than other mid-ocean ridges over similar length scales and comparable sampling density. Its degree of heterogeneity (the height of the isotopic shifts in Figure 2) appears to decrease from west to east, and thus to correlate with the regional decrease in crustal thickness, potential mantle temperature and increasing depth [Francis and Raitt, 1967; Minshull and White, 1996; Müller et al., 1997, 1999, 2000; Cannat et al., 1999; Meyzen et al., 2003]. Hence most of the isotopic heterogeneity appears to be confined to the west of the Indomed FZ. In this section, we will begin by discussion of the boundary between the easternmost SWIR and the Rodrigues Triple Junction. We will then discuss the large and small scale isotopic variations of SWIR lavas. Finally, we investigate the possible origin of the low ${ }^{206} \mathrm{~Pb} /{ }^{204} \mathrm{~Pb}$ component present in the group D3 and its role in the genesis of the distinctive Indian mantle signature.

\subsection{Regional Isotopic Heterogeneity From Large- to Small-Scale Domains Along the SWIR and in the Vicinity of the SWIR}

\subsubsection{A Boundary Between the Rodrigues Triple Junction and the Easternmost Southwest Indian Ridge}

[25] The Rodrigues Triple Junction (RTJ, $25^{\circ} 33^{\prime} \mathrm{S}$, $70^{\circ} \mathrm{E}$ ), which has been stable for about $\sim 40 \mathrm{Myr}$, connects the Southeast Indian Ridge (SEIR), the Central Indian Ridge (CIR) and the SWIR [Sclater et al., 1981; Patriat and Segouffin, 1988]. Its northeastward migration during the last $\sim 74 \mathrm{Myr}$ has produced a lengthening of the SWIR [Royer et al., 1988]. Presently, it is moving at $20 \mathrm{~mm} \mathrm{yr}^{-1}$, almost three times the half spreading rate of the eastern SWIR [Tapscott et al., 1980; Patriat et al., 1997]. Near the junction, there is no evidence from gravity data for focused upwelling beneath the SWIR limb; spreading is thus primarily amagmatic [West et al., 1995; Rommevaux-Jestin et al., 1997]. The mantle flow pattern in this region has 
thus been inferred to be principally dominated by upwelling of the two intermediate SEIR and CIR spreading ridges, leading to sampling of their lateral down flow residual mantle by the slow SWIR branch [Mitchell, 1991; West et al., 1995]. However, this view has been questioned by recent numerical 3D modeling of mantle flow and temperature structure at the RTJ, which shows that the SWIR mantle flow has a strong component of along-axis velocity directed away from the junction [Georgen and Lin, 2002]. This would result in almost no material transfer from the faster to the slower-spreading ridges [Georgen and Lin, 2002].

[26] The easternmost SWIR samples are located at a minimum distance of $\sim 78 \mathrm{~km}$ from the RTJ and are isotopically distinct from those at the junction in having lower ${ }^{87} \mathrm{Sr} /{ }^{86} \mathrm{Sr},{ }^{208} \mathrm{~Pb} /{ }^{204} \mathrm{~Pb}$ and ${ }^{207} \mathrm{~Pb} /{ }^{204} \mathrm{~Pb}$ for a given ${ }^{206} \mathrm{~Pb} /{ }^{204} \mathrm{~Pb}$ (Figures 2, 3, 5 , and 7). The isotopic discontinuity between lavas from the RTJ and those from the easternmost SWIR was first recognized by Mahoney et al. [1989], who attributed it to either (1) isotopically distinct mantle domains whose boundary coincides with the RTJ or (2) a vertically zoned mantle, which is sampled differentially due to contrasts in fertility or as a result of differences in mantle temperature under the ridges.

[27] If the mantle is vertically zoned with blobs of low ${ }^{206} \mathrm{~Pb} /{ }^{204} \mathrm{~Pb}$ material present below the site of onset of melting of the SWIR mantle (assuming that melting begins at greater depth beneath the RTJ than the SWIR), a correlation between the mean axial depth and $\mathrm{Pb}$ isotopes for lavas from the SWIR and RTJ would be expected. Although not shown, there is no such isotopic correlation. The isotopic discontinuity observed between the easternmost SWIR and the RTJ appears therefore to be the surface expression of a rather abrupt boundary between different mantle domains, supporting the numerical modeling of Georgen and Lin [2002]. A similar isotopic boundary should exist between the CIR and the RTJ, as mantle flow beneath the CIR is predicted to be directed away from the junction [Georgen and Lin, 2002]. However, the northward extent of the RTJ domain along the CIR cannot be precisely determined due to a lack of geochemical data on the CIR between $21.5^{\circ}$ and $24.9^{\circ} \mathrm{S}$. Discussion on whether or not mantle flow patterns presently observed at the RTJ have persisted through time and space is rather speculative and would require further off-axis sampling of the fossil RTJ.

\subsubsection{Isotopic Provinces in the SWIR Mantle}

\subsubsection{Large-Scale Isotopic Variations}

[28] To a first approximation, the $\mathrm{Pb}$ isotopes show some evidence for a subtle, but irregular regional variation in source composition (increase in $\Delta 8 / 4$ going from west to east, broadly correlated with a decrease in ${ }^{206} \mathrm{~Pb} /{ }^{204} \mathrm{~Pb}$, Figure 2), which may reflect some form of large-scale mantle flow and mixing. This compositional gradient has previously been proposed to arise from the dispersion of the low ${ }^{206} \mathrm{~Pb} /{ }^{204} \mathrm{~Pb}$ component sampled by the section D3 by Marion, Kerguelen and Crozet plumes during the breakup of Gondwanaland. This component was then carried by shallow level convection following the northerly to northeasterly spreading direction of the Indian plate during the period of superfast spreading from 80 to 43 Ma [Mahoney et al., 1992]. However, this model is not supported by our isotopic data. Toward the east, the baseline ${ }^{87} \mathrm{Sr} /{ }^{86} \mathrm{Sr}$ broadly decreases to $\sim 65^{\circ} \mathrm{E}$, instead of increasing as would be expected (Figure 2). The longitudinal ${ }^{143} \mathrm{Nd} /{ }^{144} \mathrm{Nd}$ profile does not show any clear decreasing gradient from west to east along the area studied (Figure 2).

[29] As mentioned above, the degree of source heterogeneity seems to decrease from west to east, and thus correlates with the regional decrease in crustal thickness, potential mantle temperature and increasing depth [Francis and Raitt, 1967; Minshull and White, 1996; Müller et al., 1997, 1999, 2000; Cannat et al., 1999; Meyzen et al., 2003]. Furthermore, the largest isotopic diversity appears to be restricted to the west of the Indomed FZ and is thus not related to the eastward decrease of the full spreading rate (from $\sim 1.6 \mathrm{~cm} \mathrm{yr}^{-1}$ to $\sim 1.2 \mathrm{~cm} \mathrm{yr}^{-1}$ [Chu and Gordon, 1999]) along the area studied. Allegre et al. [1984] argued that isotopic diversity is inversely related to spreading rate, resulting from less effective homogenization of heterogeneities by magmatic processes at slow to ultra slow spreading ridge. Other researchers have questioned this fact as for example low, instead of high variability of ${ }^{3} \mathrm{He} /{ }^{4} \mathrm{He}$ is observed in SWIR basalts relative to other MORB [e.g., White et al., 1987; Georgen et al., 2003]. Our SWIR data also discounts a relationship with spreading rate. Alternatively, as the greatest isotopic diversity occurs in the vicinity of fracture zones, this may be related to a local transform fault effect, as discussed below. 


\subsubsection{Role of Transform Faults}

[30] The studied section of the SWIR is characterized by the presence of transform faults, simple strike-slip translational plate boundaries, which offset the ridge axis laterally in the direction of plate motion. These tectonic lithospheric features are usually associated with a decrease in crustal thickness and an increase in axial depth, reflecting a locally colder mantle temperature due to conductive heat loss through the adjacent older lithosphere [Langmuir and Bender, 1984; Shen and Forsyth, 1995]. At transform-ridge intersections, where low degrees of melting are predicted, veins enriched in volatile, large-ion lithophile elements, and radiogenic $\mathrm{Pb}$ and $\mathrm{Sr}$ would be expected to contribute in greater proportion to the liquid relative to the depleted matrix [Langmuir and Bender, 1984]. Such gradients toward more enriched signatures are only found in the shallowest part of the ridge (Figure 2), in the vicinity of the Indomed Fracture Zone (group C2) and the Eric Simpson Fracture Zone (group D3), where the regional mantle temperature is expected to be hottest. To a first approximation, this observation is consistent with the fact that such an effect would be expected to be enhanced when the regional mantle temperature is hot rather than cold. However, detailed examination shows that the maxima in $\Delta 8 / 4$ and ${ }^{87} \mathrm{Sr} /{ }^{86} \mathrm{Sr}$ for the group D3 do not occur adjacent to the transform, suggesting that these maxima may not be controlled by a transform fault effect. In addition, previous geochemical studies of the major and trace element compositions of MORB over this area have emphasized the absence of a transform fault effect [LeRoex et al., 1989].

[31] Finally, at least to the east of the Indomed Fracture Zone, steps in isotopic compositions in $\mathrm{Pb}$ and to a lesser extent in $\mathrm{Nd}$ between different isotopic domains coincide with the locations of long-offset (>90 km) transform faults (e.g., Gallieni, Atlantis $\Pi$ and Melville FZs), which indicate that there is no continuity in mantle flow beneath these fracture zones (Figure 2). Although transform faults have been shown to correspond in some areas with isotopic boundaries (e.g., Hayes Fracture Zone, Kane Fracture zone and Southern Chile Ridge [Machado et al., 1982; Smith et al., 1998; Sturm et al., 1999]), it is far from being a general feature along the worldwide mid-ocean ridge system.

\subsubsection{Small-Scale Isotopic Domains}

[32] Overall, given the present sampling, the extents of small-scale isotopic domains do not co- incide with bathymetric segmentation (Figures $1 \mathrm{~b}-$ 2 ). In other words, the trends (Figures 3-7) defined by the groups are not generally geographically restricted to one segment, and continue across segment boundaries, with the exception of the group B2. The presence of these small-scale isotopic domains does not appear to be a characteristic inherent to regions of ultra-slow spreading rate. Such domains spanning a few degrees of longitude (less than $1^{\circ}$ to $5^{\circ}$ ) have also been found along the East Pacific Rise and the Southern Chile Ridge [White et al., 1987; Sturm et al., 1999, Galer et al., 1999].

[33] The spatial distribution observed here indicates that the SWIR mantle is heterogeneous at shallow level with respect to $\mathrm{Pb}, \mathrm{Nd}$ and to a lesser extent, $\mathrm{Sr}$ isotopes. The degree of heterogeneity, or at least the sampling of these heterogeneities, appears to diminish from west to east along the ridge. $\mathrm{In} \mathrm{Pb}$ isotope space, the arrays defined by the most radiogenic sections do not trend toward the same depleted end-member composition and do not converge on the component defined by the $57-61^{\circ}$ section, which clearly suggests the existence of different "depleted" ambient mantle compositions (Figures 3 and 4). As shown by the fan described by these arrays in ${ }^{208} \mathrm{~Pb} /{ }^{204} \mathrm{~Pb}$ versus ${ }^{206} \mathrm{~Pb} /{ }^{204} \mathrm{~Pb}$ at high ${ }^{206} \mathrm{~Pb} /{ }^{204} \mathrm{~Pb}$ (Figure 3b-4b), different components characterized by distinct ${ }^{208} \mathrm{~Pb} /{ }^{204} \mathrm{~Pb}$ are involved in the mixing relationships, and must be present as streaks in the upper mantle, and are not related to flow from mantle plumes such as Crozet to the east of Gallieni FZ. Alternatively, recent in situ $\mathrm{Pb}$-isotope studies of olivine-hosted melt inclusions for OIB reveal extreme ${ }^{207} \mathrm{~Pb} /{ }^{206} \mathrm{~Pb}-$ ${ }^{208} \mathrm{~Pb} /{ }^{206} \mathrm{~Pb}$ heterogeneity, at the sample scale [Saal et al., 1998], which may arise from a locally heterogeneous source [Hofmann, 2003]. The scales of heterogeneities observed along the SWIR may thus reflect distinct scales of homogenization resulting from mixing during the aggregation process of primary liquids and melting process (e.g., volume of melting) rather than the melting of different heterogeneous sources. Shallow level mixing and homogenization processes would dampen much of the source heterogeneity.

[34] Along the SWIR, there is thus no evidence for vigorous, widespread and long-term convection which would have efficiently homogenized the mantle, at least at the scale of present sampling, $>\sim 308 \mathrm{~km}$. Future mapping by high precision $\mathrm{Pb}$ isotopes of small scale isotopic domains and un- 
derstanding of how these domains maintain their integrity should prove useful for understanding the geometry of mantle heterogeneity and mixing process, as well as for the detailed origin of isotopic variations of the upper mantle.

\subsection{Origin of the Low ${ }^{206} \mathrm{~Pb} /{ }^{204} \mathrm{~Pb}$ Component and Mixing Relationships in the Indian Ocean Mantle}

\subsubsection{Origin of the Low ${ }^{206} \mathrm{~Pb} /{ }^{204} \mathrm{~Pb}$ Component Observed Between 39 and $41^{\circ}$ E Section: Recycled Oceanic Components Versus Recycled Continental Components}

[35] Lavas from the $39-41^{\circ} \mathrm{E}$ section, along with those from the Aphanasy-Nikitin Rise are of particular interest as they exhibit by far the strongest typical Indian signatures yet found in the Indian Ocean. These anomalies are highly focused on these two particular regions, but the component is variably distributed throughout the Indian Ocean mantle source (Figures 8 and 9).

[36] Isotopically, the shapes of the fields, and especially the quadrilateral pattern defined by these lavas in ${ }^{143} \mathrm{Nd} /{ }^{144} \mathrm{Nd}$ and ${ }^{87} \mathrm{Sr} /{ }^{86} \mathrm{Sr}$ versus ${ }^{208} \mathrm{~Pb} /{ }^{204} \mathrm{~Pb}$ require the involvement of more than two end-members (Figure 5). Their isotopic compositions indicate a weaker contribution of melts from a normal MORB mantle beneath this part of the SWIR, and hence a higher contribution of melts arising from a low ${ }^{206} \mathrm{~Pb} /{ }^{204} \mathrm{~Pb}$ component. Below we discuss several possible origins for the low ${ }^{206} \mathrm{~Pb} /{ }^{204} \mathrm{~Pb}$ component of the $39-41^{\circ} \mathrm{E}$ lavas.

\subsubsection{Hot Spot}

[37] Although lavas from the group D3 geographically fall in the southern extension of the Madagascar Rise, which is the presumed post-80 Ma trace of the Marion hot spot on the African plate (Figures 1 and 2) [Storey et al., 1995], they do not trend toward the Marion hot spot field, as clearly emphasized by their ${ }^{207} \mathrm{~Pb} /{ }^{204} \mathrm{~Pb}-{ }^{206} \mathrm{~Pb} /{ }^{204} \mathrm{~Pb}$ variations (Figure $3 \mathrm{a}$ ). In addition, on a world-wide scale, no present-day hot spots exhibit the isotopic heterogeneity that would be required, not even the EM1 type Ocean Island Basalts from Walvis Ridge, Kerguelen and Pitcairn islands (Figures 10 and 11). There is also no evidence that the low ${ }^{206} \mathrm{~Pb} /{ }^{204} \mathrm{~Pb}$ component is an intrinsic feature of the present-day Marion hot spot, as would be expected by the presence of the two types of lavas within the anomaly. However, paradoxically, isotopic compositions of lavas from both sections (groups D2 and D4) adjacent to the group D3 can be accounted for by a mixture of Marion hot spot and the depleted endmember expressed by Discovery lavas (group D1) (Figures 3, 5, and 7). Lavas from the group D2 fall very close to or overlap the field defined by the Marion hot spot. Those from the section D4 fall along possible mixing curves between Marion hot spot and Discovery lavas (Figures 3, 5, and 7). This binary model is further supported by a Principal Component Analysis using the $\mathrm{Pb}$ isotope ratios (relative to ${ }^{206} \mathrm{~Pb}$ ) where $98.4 \%$ of the variance is confined to the first principal axis. Even the scatter observed in ${ }^{143} \mathrm{Nd} /{ }^{144} \mathrm{Nd}$ and ${ }^{87} \mathrm{Sr} /{ }^{86} \mathrm{Sr}$ versus ${ }^{208} \mathrm{~Pb} /{ }^{204} \mathrm{~Pb}$ is consistent, provided that $\mathrm{a}$ certain degree of heterogeneity is allowed in the two end-members. The calculated contribution of Marion hot spot material ranges from 10 to $50 \%$ consistent with a contribution of $\sim 40 \%$ proposed by Mahoney et al. [1992] in the source of lavas from the section D4. However, the complex, irregular and asymmetric dispersion of enriched mantle associated with the Marion plume along the ridge axis appears to be inconsistent with radial mixing models such as those established for faster spreading ridges [e.g., Schilling et al. 1999].

\subsubsection{Sediment}

[38] Sedimentary material in the oceanic mantle could result from recycling via subduction of oceanic lithosphere [e.g., Hofmann and White, 1982; Weaver, 1991]. The composition of a deep sea sediment column is a function of its lithological constituents which are a function of the different detrital sources and of the sedimentation rate [Plank and Langmuir, 1998]. Many sediments have low ${ }^{238} \mathrm{U} /{ }^{204} \mathrm{~Pb}$ ratios $(2-6)$ meaning that old sediment might be characterized by low ${ }^{206} \mathrm{~Pb} /{ }^{204} \mathrm{~Pb}$ compared to modern values [e.g., Ben Othman et al., 1989; Rehkämper and Hofmann, 1997].

[39] Considering the "erosion mix" curves [Kramers and Tolstikhin, 1997; Nägler and Kramers, 1998], which represent the modeled $\mathrm{Nd}-\mathrm{Pb}$ isotopic evolution of terrestrial sediment that has been subducted into the mantle throughout Earth's history, it may be assessed whether the $\mathrm{Pb}$ $\mathrm{Nd}$ isotopic characteristics of group D3 can be of sedimentary origin or not. From the "erosion mix $\mathrm{Pb}$ curve," the $\mu$ required to produce lavas from the group D3 via the ${ }^{235} \mathrm{U}$ and ${ }^{238} \mathrm{U}$ decay equations has been calculated. For the whole group D3, the solutions converge at $\sim 3.55 \mathrm{Ga}$. The group D3 can 


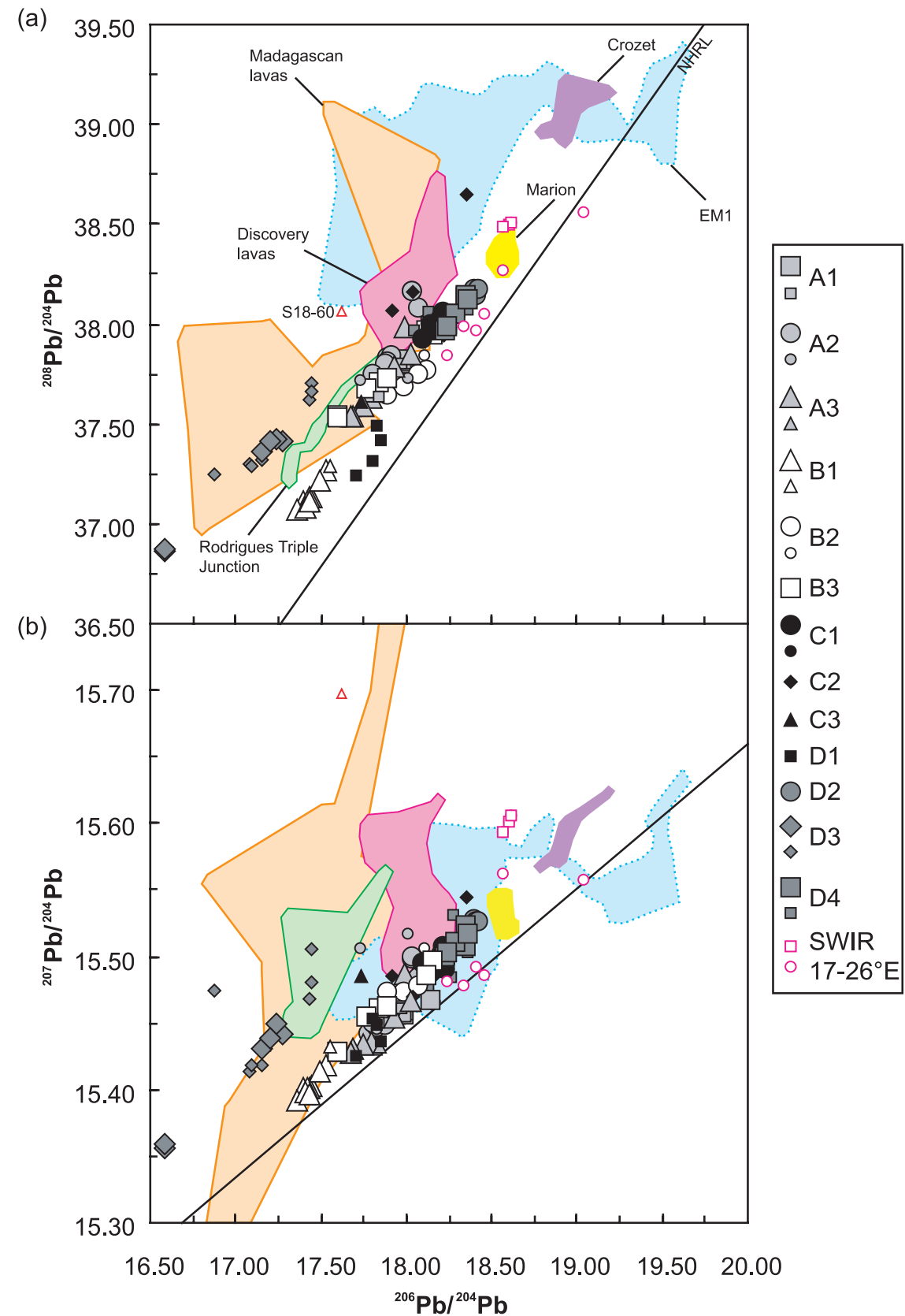

Figure 10. SWIR lavas (a) ${ }^{208} \mathrm{~Pb} /{ }^{204} \mathrm{~Pb}$ and (b) ${ }^{207} \mathrm{~Pb} /{ }^{204} \mathrm{~Pb}$ against ${ }^{206} \mathrm{~Pb} /{ }^{204} \mathrm{~Pb}$ variations compared to Discovery lavas [Douglass et al., 1999], sample S18-60 from the southern mid-Atlantic ridge near the Bouvet Triple junction [Kamenetsky et al., 2001], Madagascan lavas [Mahoney et al., 1991; Storey et al., 1997], and global isotopic endmember EM1 (See Auxiliary Material for references used). Data sources for previous SWIR lavas (small symbols) as in Figure 2.

be derived from "erosion mix" with initial ${ }^{206} \mathrm{~Pb} /{ }^{204} \mathrm{~Pb},{ }^{207} \mathrm{~Pb} /{ }^{204} \mathrm{~Pb}$ and ${ }^{208} \mathrm{~Pb} /{ }^{204} \mathrm{~Pb}$ values of $12.03,13.83$ and 31.67 with a $\mu$ of 6.92 and a ${ }^{232} \mathrm{Th} /{ }^{238} \mathrm{U}(\kappa)$ of 4.27 at $3.55 \mathrm{Ga}$. All these $\mu$ and $\kappa$ values are well within the range of those observed for sediment. However, the initial value obtained for ${ }^{143} \mathrm{Nd} /{ }^{144} \mathrm{Nd}$ of 0.5125 at $\sim 3.55 \mathrm{Ga}$, is very close to the present-day average composition of the group D3 (0.5127), requiring an unrealistic low ${ }^{447} \mathrm{Sm} /{ }^{144} \mathrm{Nd}(0.010)$ for the sediment component (0.10-0.17, [Strake et al., 2003]). Therefore the $\mathrm{Nd}-\mathrm{Pb}$ systematics cannot be accounted for by the presence of sediment in the source, given current constraints on such modeling. Further evidence 
(a)

(b)

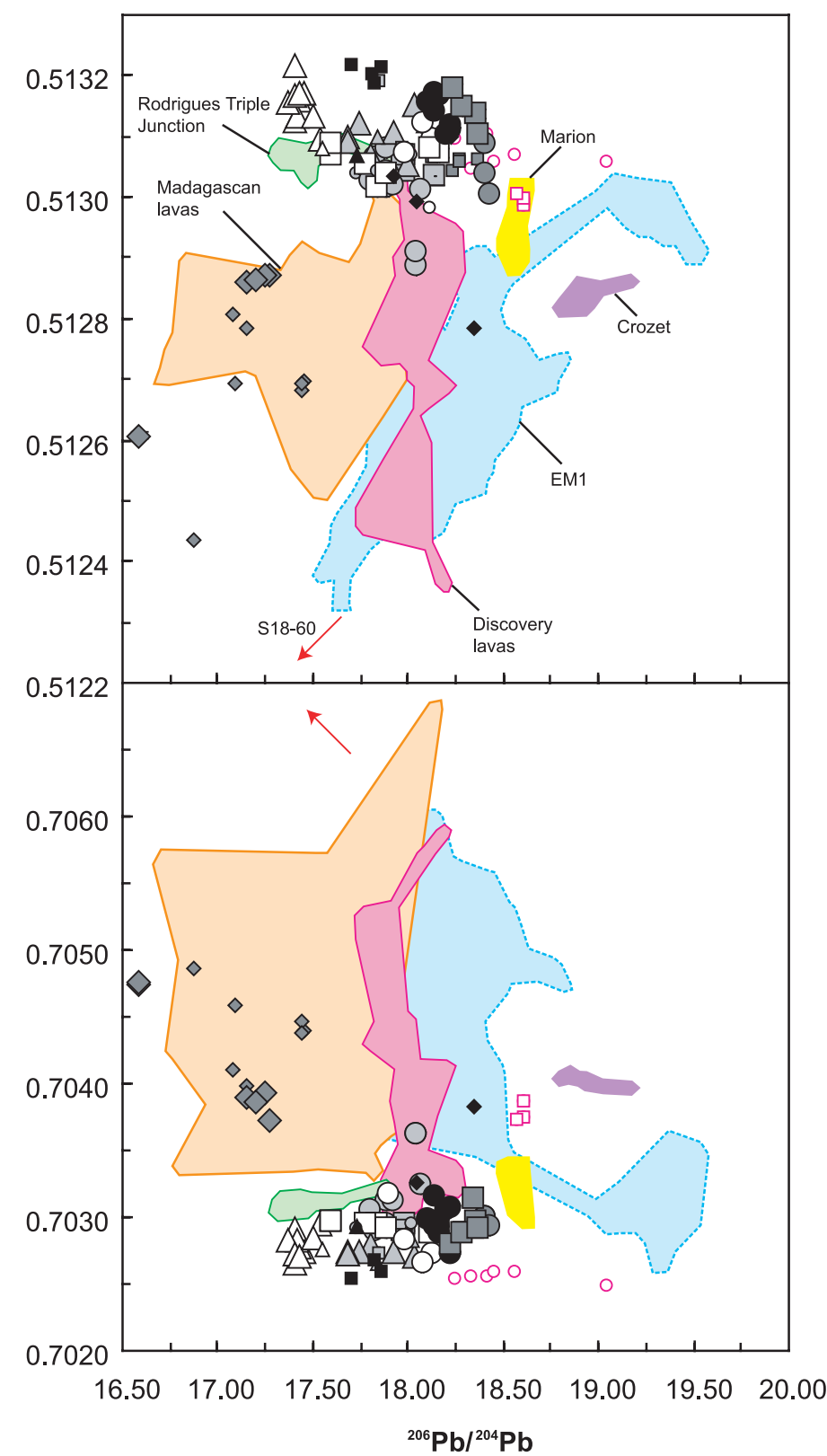

Figure 11. SWIR lavas (a) ${ }^{143} \mathrm{Nd} /{ }^{144} \mathrm{Nd}$ and (b) ${ }^{87} \mathrm{Sr} /{ }^{86} \mathrm{Sr}$ against ${ }^{206} \mathrm{~Pb} /{ }^{204} \mathrm{~Pb}$ variations compared to Discovery lavas [Douglass et al., 1999], sample S18-60 from the southern mid-Atlantic ridge near the Bouvet Triple junction [Kamenetsky et al., 2001], Madagascan lavas [Mahoney et al., 1991; Storey et al., 1997], and global isotopic endmember EM1 (See Auxiliary Material for references used). Data sources for previous SWIR lavas (small symbols) as in Figure 2.

against sediment as a component of D3 lavas is provided by their relatively variable ${ }^{207} \mathrm{~Pb} /{ }^{204} \mathrm{~Pb}$ and relatively constant ${ }^{208} \mathrm{~Pb} /{ }^{204} \mathrm{~Pb}$ (Figure 3) and hence variable $\mathrm{U} / \mathrm{Pb}$ and constant $\mathrm{Th} / \mathrm{Pb}$ parent/ daughter ratios, as no group of sediments has variable $\mathrm{U} / \mathrm{Pb}$ and constant $\mathrm{Th} / \mathrm{Pb}$ parent daughter ratios [Strake et al., 2003; Ben Othman et al. 1989]. These characteristics can also not arise from subduction processing, as sediment melting and fluid sediment release processes affect the $\mathrm{Th} / \mathrm{Pb}$ and $\mathrm{U} / \mathrm{Pb}$ of sediment to a similar degree, leading to preservation of the $\mathrm{U} / \mathrm{Pb}$ and $\mathrm{Th} / \mathrm{Pb}$ features [Strake et al., 2003]. Therefore recycled oceanic components, sediment \pm oceanic crust can also be discarded as source components for the group D3. Similar conclusions have been recently reported at 
Table 3. Melting Model Results ${ }^{\mathrm{a}}$

\begin{tabular}{|c|c|c|c|c|c|c|c|c|c|c|}
\hline & \multicolumn{3}{|c|}{ Partition Coefficient } & \multirow[b]{2}{*}{$\mathrm{Sp}$} & \multirow[b]{2}{*}{ Bulk D } & \multicolumn{2}{|c|}{ Garrett Lavas } & \multicolumn{2}{|c|}{ Aleutian Lavas } & \multirow[b]{2}{*}{ Cwedge } \\
\hline & $\mathrm{Ol}$ & Cpx & Opx & & & $(\mathrm{CL})_{8}$ & $\mathrm{C}_{0}$ & $(\mathrm{CL})_{6}$ & $\mathrm{C}_{0}$ & \\
\hline $\mathrm{Na}$ & - & - & - & - & 0.030 & 2.70 & 0.3 & - & - & - \\
\hline $\mathrm{Pb}$ & 0.0076 & 0.020 & 0.0013 & - & 0.018 & 0.42 & 0.041 & 4.82 & 0.70 & 0.024 \\
\hline Th & 0.000014 & 0.021 & 0.0032 & 0.001 & 0.005 & 0.06 & 0.006 & 1.44 & 0.21 & 0.0041 \\
\hline $\mathrm{U}$ & 0.000059 & 0.018 & 0.0047 & 0.001 & 0.005 & 0.09 & 0.008 & 0.72 & 0.10 & 0.0020 \\
\hline${ }^{206} \mathrm{Pr} / 204 \mathrm{Ph}$ & 0.00015 & 0.18 & 0.027 & 0.05 & 0.043 & - & - & 78.72 & 12.93 & 18854 \\
\hline${ }^{207} \mathrm{~Pb} /{ }^{204} \mathrm{~Pb}$ & & & & & & & $\begin{array}{l}17.754 \\
15.374\end{array}$ & & & $\begin{array}{l}18.854 \\
15.568\end{array}$ \\
\hline${ }^{208} \mathrm{~Pb} /{ }^{204} \mathrm{~Pb}$ & & & & & & & 37.131 & & & 38.396 \\
\hline
\end{tabular}

${ }^{\mathrm{a}} \mathrm{Pb}, \mathrm{U}$, and Th concentrations are in ppm. The isotopic average composition of the depleted Pacific is from Wendt et al. [1999]. The isotopic average composition of the wedge source is from Miller et al. [1994], George et al. [2003, 2004], and Class et al. [1999]. Fractionation corrected concentration at $\mathrm{MgO}=6 \%$ and $\mathrm{MgO}=8 \%$ are determined from regression from the Aleutian arc and Garrett transform lavas [Class et al., 1999; Wendt et al., 1999; Miller et al., 1994; George et al., 2003, 2004] following the approach developed by Klein and Langmuir [1987], Plank and Langmuir [1988], and Langmuir et al. [1992]. Data are filtered out between 5 and $8.5 \% \mathrm{MgO}$ for normalized oxides. The initial mode is from Kinzler and Grove [1992]. The partition coefficients are from McDade et al. [2003], McKenzie and O'Nions [1991], Dunn and Sen [1994], and Niu et al. [1999].

the basin wide scale by several investigators [Kempton et al., 2002; Escrig et al., 2004].

\subsubsection{Subduction Modified Subarc Mantle}

[40] An alternative origin for the $39-41^{\circ}$ section (group D3) is that it represents subduction modified subarc mantle, which has undergone metasomatism and melting at the subduction zone before being recycled into the deep mantle through viscous coupling to the down going slab. Recently, on the basis of Hf-Nd systematics, Kempton et al. [2002] have argued that the distinct nature of Indian MORB may originate from the presence of a substantial proportion of material arising from subduction modified mantle embedded in the shallow asthenosphere. However, this model has not been constrained for $\mathrm{Pb}$ isotopes. A first step to model the $\mathrm{Pb}$ isotope composition of subduction modified subarc mantle is to find an oceanic arc which does not exhibit an Indian-like signature. Most (if not all) oceanic arc lavas currently produced within the western Pacific Ocean arise from Indian type mantle [Hergt and Hawkesworth, 1994; Shinjo et al., 2000]. Among other arcs, the second and central Aleutian arcs meet these requirements. In order to determine the $\mathrm{U}, \mathrm{Pb}$ and Th contents of the residual mantle wedge, we have assumed that the Aleutian average in $\mathrm{Zr}_{6.0}(\mathrm{Zr}$ normalized to $6 \% \mathrm{MgO}$ [Plank and Langmuir, 1988]) represents a $14 \%$ accumulated fractional melt assuming that (1) negligible amounts of $\mathrm{Zr}$ are added during subduction and (2) the $\mathrm{Zr}$ content of the mantle wedge is equal to that of the depleted Pacific mantle. The U-Th-Pb contents of the residual wedge can then be estimated from the average composition of these lavas as we know the extent of melting and the partition coefficients of $\mathrm{U}$, Th and $\mathrm{Pb}$. The average isotope composition of these arc lavas can then be corrected back in time. A broadly similar approach is used to age-correct the average isotope composition of the depleted Pacific mantle taken as being represented by Garrett transform lavas. $\mathrm{U}, \mathrm{Th}$ and $\mathrm{Pb}$ contents are inversely calculated assuming that the average in $\mathrm{Na}_{8.0}$ of lavas from the Garrett transform fault [Wendt et al., 1999] represents a $9 \%$ accumulated fractional melt. The parameters and details of the calculations are given in Table 3. Knowing all these parameters, we can then determine the present-day isotopic composition using the ${ }^{235} \mathrm{U},{ }^{238} \mathrm{U}$ and ${ }^{232} \mathrm{Th}$ decay equations of an old mixture between these components. Both Indian and Atlantic Oceans overly a mantle cell, which has contained all continents for at least $400 \mathrm{Myr}$, meaning that it has been circled and crossed by subduction zones [Collins, 2003]. We thus have assumed a mixture occurring $400 \mathrm{Myr}$ ago between a depleted Pacific mantle and a subarc wedge. The attributes of the composition of the present-day mixture cannot represent a plausible end-member for the group D3 (see Figure 12). Similar conclusions are valid for more ancient components as old subduction modified subarc mantle does not yield high enough ${ }^{207} \mathrm{~Pb} /{ }^{204} \mathrm{~Pb}$ and ${ }^{208} \mathrm{~Pb} /{ }^{204} \mathrm{~Pb}$ to explain the group D3 (Figure 12a). Nevertheless, the presence of recycled metasomaticmantle components merits further investigation, as dewatering slab processes have been a major process throughout Earth history.

\subsubsection{Sublithospheric Continental Mantle}

[41] The observation of isotopic similarities between cretaceous alkali lavas from Madagascar 


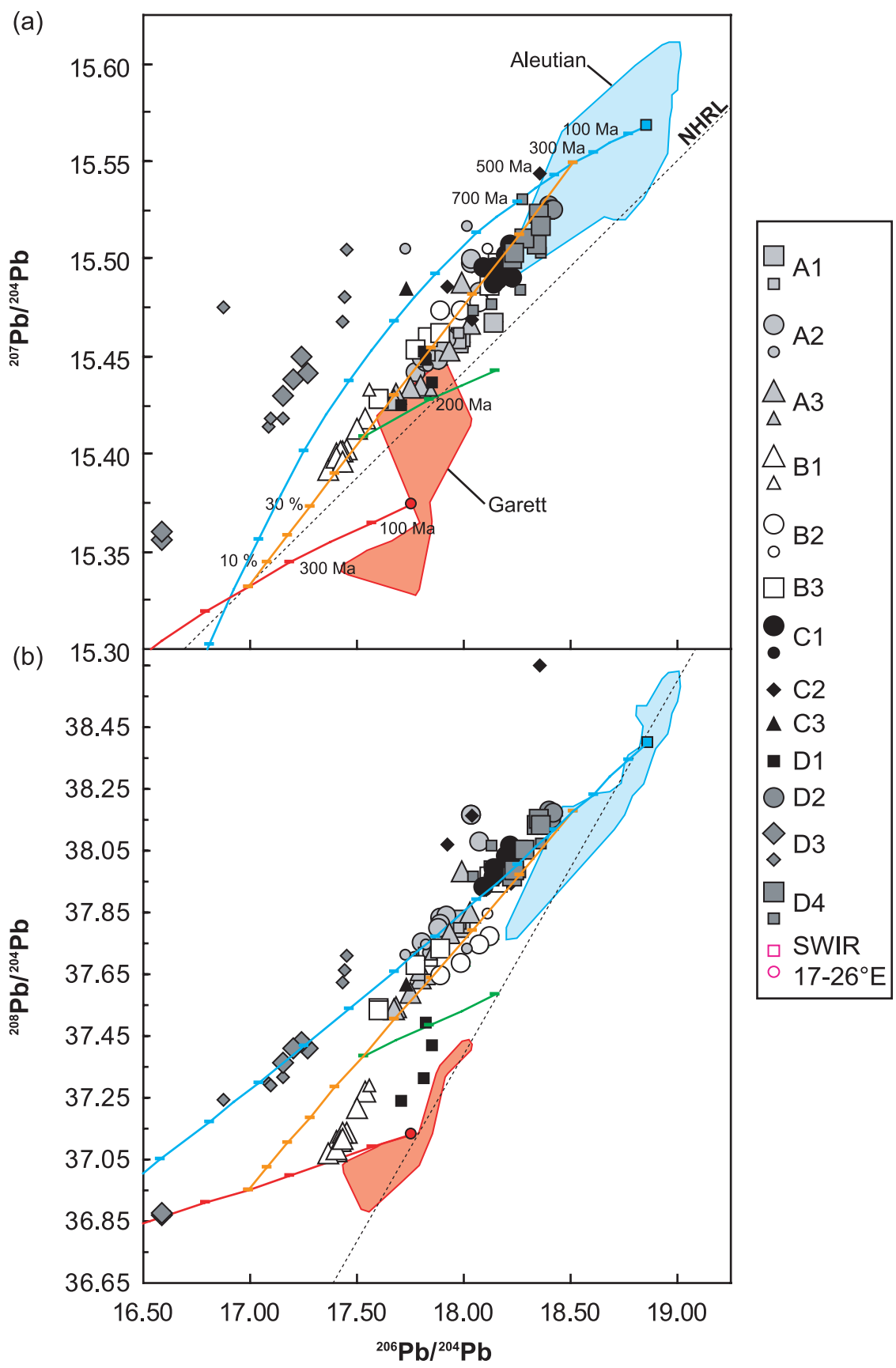

Figure 12. Diagrams of (a) ${ }^{207} \mathrm{~Pb} /{ }^{204} \mathrm{~Pb}$ and (b) ${ }^{208} \mathrm{~Pb} /{ }^{204} \mathrm{~Pb}$ versus ${ }^{206} \mathrm{~Pb} /{ }^{204} \mathrm{~Pb}$ which demonstrate the mixing systematics of the proposed mantle wedge contamination model. The isotopic compositions of SWIR lavas, as well as fields for Aleutians lavas [Miller et al., 1994; George et al., 2003, 2004; Class et al., 1999] and Garrett transform lavas [Wendt et al., 1999], are shown for comparison. The blue and red curves represent the initial compositions of the mantle wedge and of the depleted Pacific mantle, respectively, recalculated by age correction every 200 Myr. The orange curve is the mixture of these two end-members at $400 \mathrm{Ma}$ with steps of $10 \%$. The green curve is the isotopic composition of the mixture from $400 \mathrm{Ma}$ to present-day, graduated by $200 \mathrm{Myr}$.

and lavas from the $39-41^{\circ} \mathrm{E}$ section (e.g., low ${ }^{206} \mathrm{~Pb} /{ }^{204} \mathrm{~Pb}$, high ${ }^{208} \mathrm{~Pb} /{ }^{204} \mathrm{~Pb}$, high ${ }^{207} \mathrm{~Pb} /{ }^{204} \mathrm{~Pb}$, low ${ }^{143} \mathrm{Nd} /{ }^{144} \mathrm{Nd}$ and high ${ }^{87} \mathrm{Sr} /{ }^{86} \mathrm{Sr}$ ) led Mahoney et al. [1992] to suggest that they tap the same component, the Madagascan continental litho- sphere (Figures 10 and 11). A portion of Madagascan lithosphere may have been thermally eroded from Indo-Madagascar by the action of the Marion hot spot and incorporated within the shallow asthenosphere just before the breakaway of 


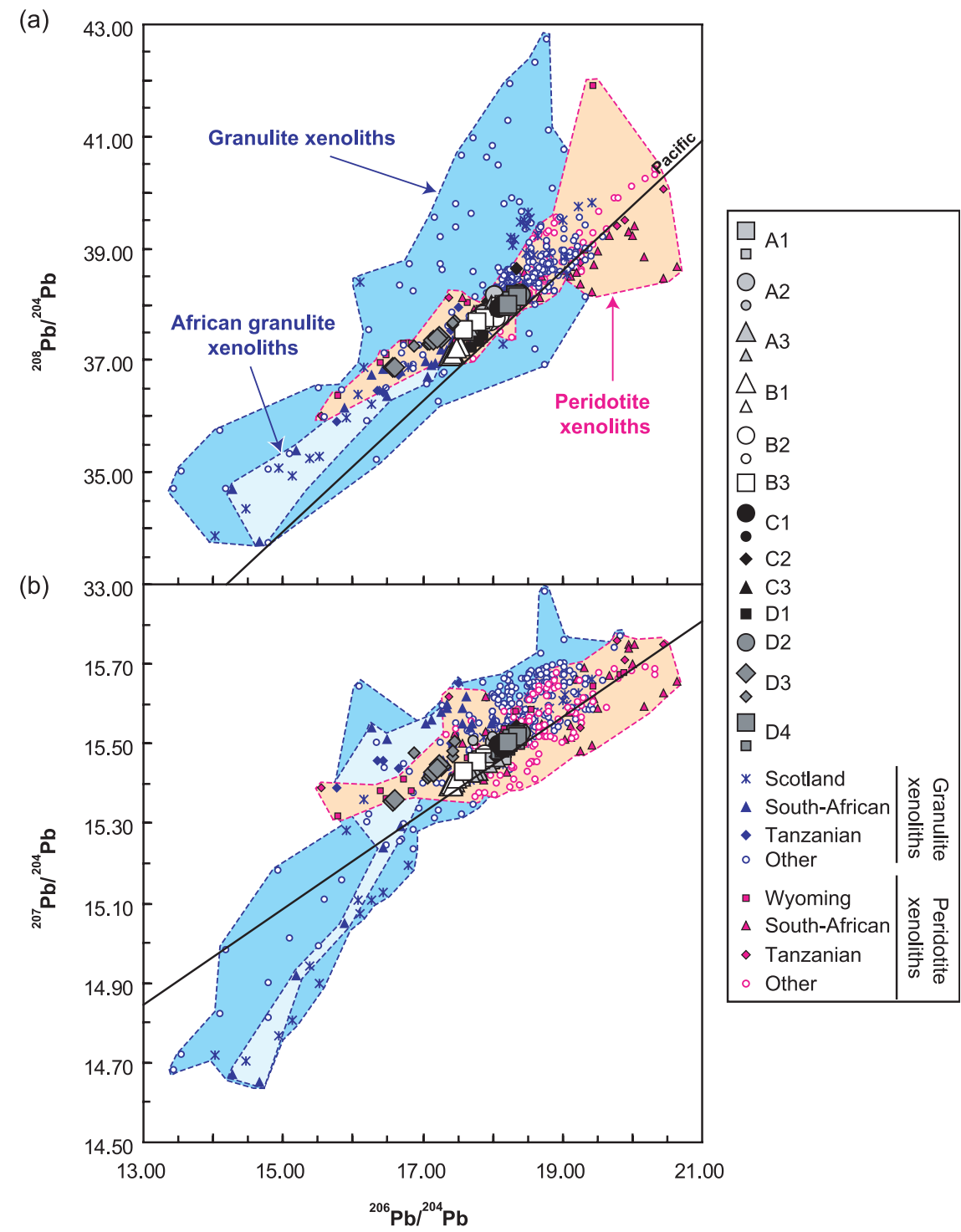

Figure 13. SWIR lavas (a) ${ }^{208} \mathrm{~Pb} /{ }^{204} \mathrm{~Pb}$ and (b) ${ }^{207} \mathrm{~Pb} /{ }^{204} \mathrm{~Pb}$ against ${ }^{206} \mathrm{~Pb} /{ }^{204} \mathrm{~Pb}$ variations compared to granulite, peridotite xenoliths, and Pacific array. See Auxiliary Material for references used. The Pacific array has been determined by a regression line through the data from Figures 8 and 9. Data sources for previous SWIR lavas (small symbols) as in Figure 2.

Madagascar from greater India [Mahoney et al., 1992]. Such contamination models supported by plume activity have been invoked to account for the distinctive signature of MORBs from the Indian and South Atlantic Oceans [Douglass et al., 1999; Mahoney et al., 1992]. In turn, some lavas from the Discovery anomaly and from the southernmost segment of the mid-Atlantic Ridge [Kamenetsky et al., 2001], converge toward a low ${ }^{206} \mathrm{~Pb} /{ }^{204} \mathrm{~Pb},{ }^{143} \mathrm{Nd} /{ }^{144} \mathrm{Nd}$ and high ${ }^{87} \mathrm{Sr} /{ }^{86} \mathrm{Sr}$, ${ }^{207} \mathrm{~Pb} /{ }^{204} \mathrm{~Pb},{ }^{208} \mathrm{~Pb} /{ }^{204} \mathrm{~Pb}$ component, but are characterized by much higher ${ }^{206} \mathrm{~Pb} /{ }^{204} \mathrm{~Pb}$ than that of the group D3 (Figures 10 and 11).
[42] The attractiveness of the sublithospheric continental mantle as a primary source for the 39$41^{\circ} \mathrm{E}$ section and for Indian MORB in general, is its potential to act as an ancient, stagnant and highly heterogeneous reservoir due to metasomatic enrichment. However, the hypothesis that some MORB and OIB could be derived from cool, refractory sublithospheric continental mantle has been increasingly questioned [e.g., McKenzie and Bickle, 1988; Arndt and Christensen, 1992; Arndt et al., 1993; Rëkhamper and Hofmann, 1997; Kempton et al., 2002; Escrig et al., 2004]. PostArchean continental mantle lithosphere is the most 


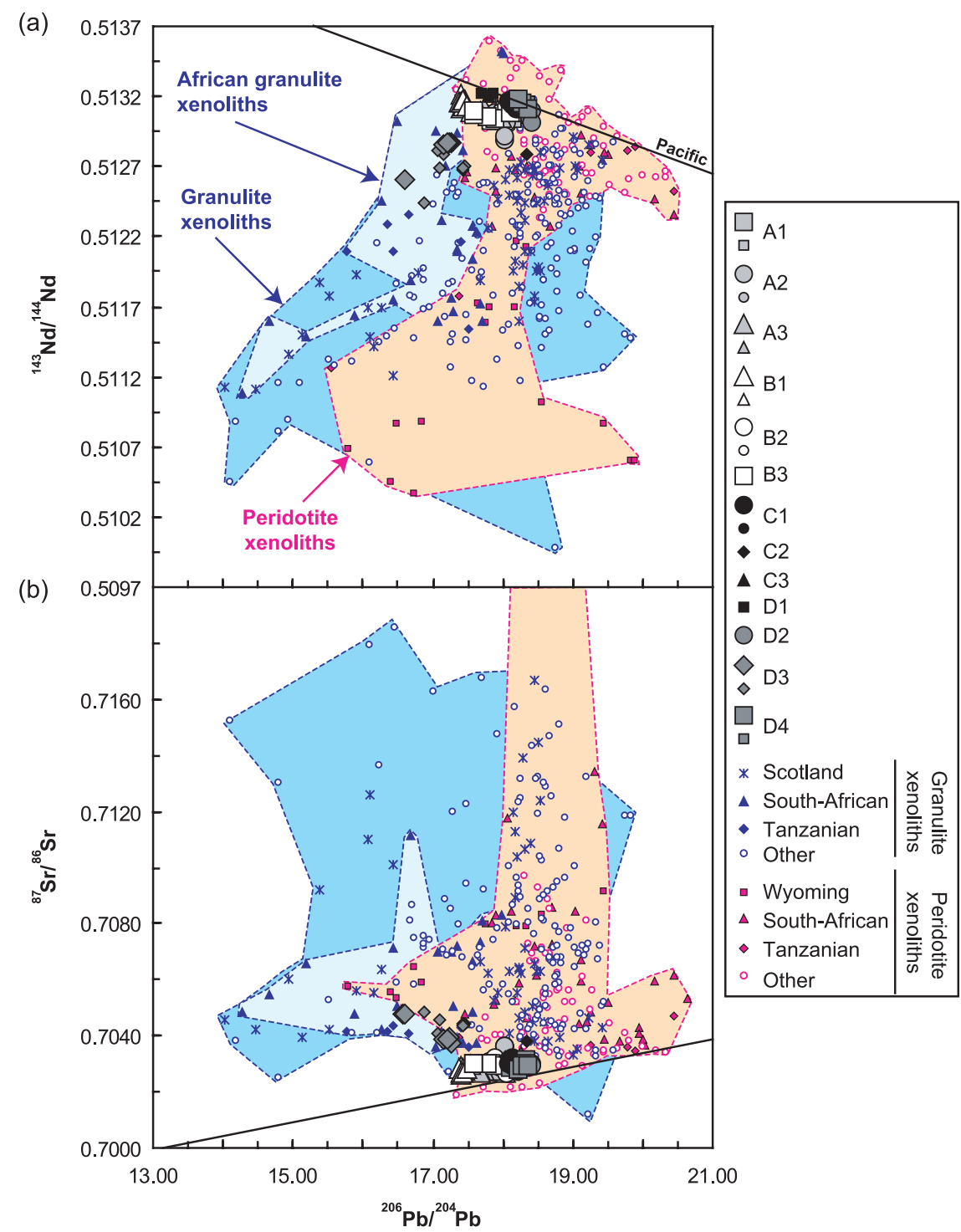

Figure 14. SWIR lavas (a) ${ }^{143} \mathrm{Nd} /{ }^{144} \mathrm{Nd}$ and (b) ${ }^{87} \mathrm{Sr} /{ }^{86} \mathrm{Sr}$ against ${ }^{206} \mathrm{~Pb} /{ }^{204} \mathrm{~Pb}$ variations compared to granulite, peridotite xenoliths, and Pacific array. See Auxiliary Material for references used. Data sources for previous SWIR lavas (small symbols) as in Figure 2.

likely lithospheric material to be removed by mantle processes because of its inherently higher density and weaker nature [Pearson and Nowell, 2002]. However, post-Archean peridotite xenoliths from southern Africa do not possess the very low ${ }^{206} \mathrm{~Pb} /{ }^{204} \mathrm{~Pb}$ signature $(<16.5)$ required to be a source component for lavas from the $39-41^{\circ} \mathrm{E}$ SWIR section (Figures 13 and 14) [Kramers, 1977; Kramers et al., 1983; Hawkesworth et al., 1990]. On a worldwide scale, even among the xenoliths assumed to represent Archean sublithospheric mantle, only two suites of xenoliths from Wyoming [Carlson and Irving, 1994] and Tanzania [Cohen et al., 1984] display low enough
${ }^{206} \mathrm{~Pb} /{ }^{204} \mathrm{~Pb}$ (Figures 13 and 14). Such signatures are extremely rare within the sublithospheric continental mantle (Figures 13 and 14). Finally, the high ${ }^{187} \mathrm{Os} /{ }^{188} \mathrm{Os}(0.3349)$ of one of the most unradiogenic ${ }^{206} \mathrm{~Pb} /{ }^{204} \mathrm{~Pb}$ sample (MD34-D5, Figure 3) of the section D3 discounts this material as being a source component for this group, as mantle xenoliths are typically characterized by subchondritic Os isotopes (on average $0.1214 \pm 0.0078$ [Escrig et al., 2004]).

\subsubsection{Lower Crust}

[43] It is possible that recycled material characterized by low $\mu$ from the lower crust is a component 
in the source of the $39-41^{\circ} \mathrm{E}$ section. The dispersion in ${ }^{207} \mathrm{~Pb} /{ }^{204} \mathrm{~Pb}$ at a given ${ }^{206} \mathrm{~Pb} /{ }^{204} \mathrm{~Pb}$ observed for group D3 requires this material to be old, in light of the rapid decay of ${ }^{235} \mathrm{U}$. "Delamination" of lower continental crust represents an alternative mechanism for recycling continental material into the convective upper mantle [e.g., Arndt and Goldstein, 1989; Turcotte, 1989; Kay and Kay, 1993]. "Delamination" sensu stricto results in a transformation of the mafic lower crust into a highdensity mineral assemblage, due to thickening and cooling processes, which then sinks into the underlying lower density mantle [Arndt and Goldstein, 1989; Turcotte, 1989; Kay and Kay, 1993]. This process is favored in environments such as arcs, volcanic rifted margins and continental areas which are experiencing extension or removal of the underlying mantle [Jull and Kelemen, 2001]. On the basis of modeling of $\mathrm{Nd}$ and Th-U-Pb system for the upper mantle, such a recycling process appears to have been important after 2-1.6 Ga [Nägler and Kramers, 1998].

[44] Whether or not lower crust is a suitable component for group D3 can be assessed from the isotopic composition of lower crustal material which is brought to the surface as garnet granulite xenoliths (Figures 13 and 14). The isotopic compositions of such xenoliths, which come from depths between 25 and $45 \mathrm{~km}$, vary greatly from one region to another depending on the nature of their protholith [e.g., Rudnick and Goldstein, 1990; Rudnick and Fountain, 1995]. At a worldwide scale, most granulite xenoliths are characterized by higher ${ }^{207} \mathrm{~Pb} /{ }^{204} \mathrm{~Pb}$ and ${ }^{208} \mathrm{~Pb} /{ }^{204} \mathrm{~Pb}$, for a given ${ }^{206} \mathrm{~Pb} /{ }^{204} \mathrm{~Pb}$ (Figure 13) and higher ${ }^{87} \mathrm{Sr} /{ }^{86} \mathrm{Sr}$ values and lower ${ }^{143} \mathrm{Nd} /{ }^{144} \mathrm{Nd}$ (Figure 14) compared to Pacific MORB. Nevertheless, a few sites (Scotland, southern Africa, and Tanzania) are characterized by extremely low $\mu$ values (Figures 13 and 14). Their low $\mu$ signature is related to Archean or Proterozoic metamorphic $U$ and Th loss from the lower crust during orogenic events, either by partial melting or fluid flushing [Downes et al., 2001]. Among these granulite xenoliths, those from the kimberlite craton-margin of southern Africa [Huang et al., 1995] which are $\sim 1.1$ Ga [Schmitz and Bowring, 2000], have the required composition to be an end-member for group D3 (Figures 13 and 14). Remnants of lower continental crust from craton margin lithosphere might have been stripped off and incorporated into the asthenosphere either during the breakup of Gondwana [Escrig et al., 2004] or during the convergence of continental plates. Similar scenarios have been proposed by several investigators to account for the features of the DUPAL basalts at the basin-wide scale [Arndt and Goldstein, 1989; Escrig et al., 2004; Hanan et al., 2004], suggesting the widespread incorporation of material from the Gondwanaland lower crust in the shallow asthenosphere during breakup of the supercontinent. Isotopically the lower crust would therefore appear to be the most reasonable petrological component responsible for the isotopic characteristics of the group D3 lavas.

\subsubsection{Mode of Incorporation}

[45] From a geodynamic perspective, the presence of a crustal component raises a number of important questions. For example, if lower crustal remnants have been thermally eroded by the Marion plume just before the breakaway of Madagascar from greater Indian and incorporated within the upper mantle, this would leave little time for this material to be dispersed throughout the present-day Indian source. In addition, during continental breakup, remnants of lower crust are expected to be pushed away from the ridge axis due to the perpendicular direction of the flow lines. This implies that remnants of lower crust during continental breakup must have been incorporated at depth where flow away from the axis was minimal, which appears an unlikely mechanism during continental breakup. Alternatively, this material may have been detached during ancient continental collision/subduction and incorporated into the upper mantle. This would require either ancient storage of this material into a discontinuity layer or ancient mixing of lower crustal material into the Indian mantle source. A recent isotopic study of Tethyan basalts and gabbros has revealed that Indian Ocean type mantle was widespread beneath the Neotethys in the Jurassic and Early Cretaceous and present beneath at least parts of the Paleothetys as long ago as the Carboniferous, arguing in favor of a rather old origin for the distinctive Indian mantle signature [Zhang et al., 2005].

\subsubsection{Mixing Model}

[46] Several models have been proposed to account for the distinctive isotopic signature of Indian MORB. Hamelin and Allègre [1985] were the first to point out the requirement of more than two distinct end-member components in the Indian mantle source. There is still controversy concerning the nature of these components, but three are generally considered: (1) a high ${ }^{143} \mathrm{Nd} /{ }^{144} \mathrm{Nd}$, low ${ }^{87} \mathrm{Sr} /{ }^{86} \mathrm{Sr}$, relatively low ${ }^{206} \mathrm{~Pb} /{ }^{204} \mathrm{~Pb}$ depleted mantle 


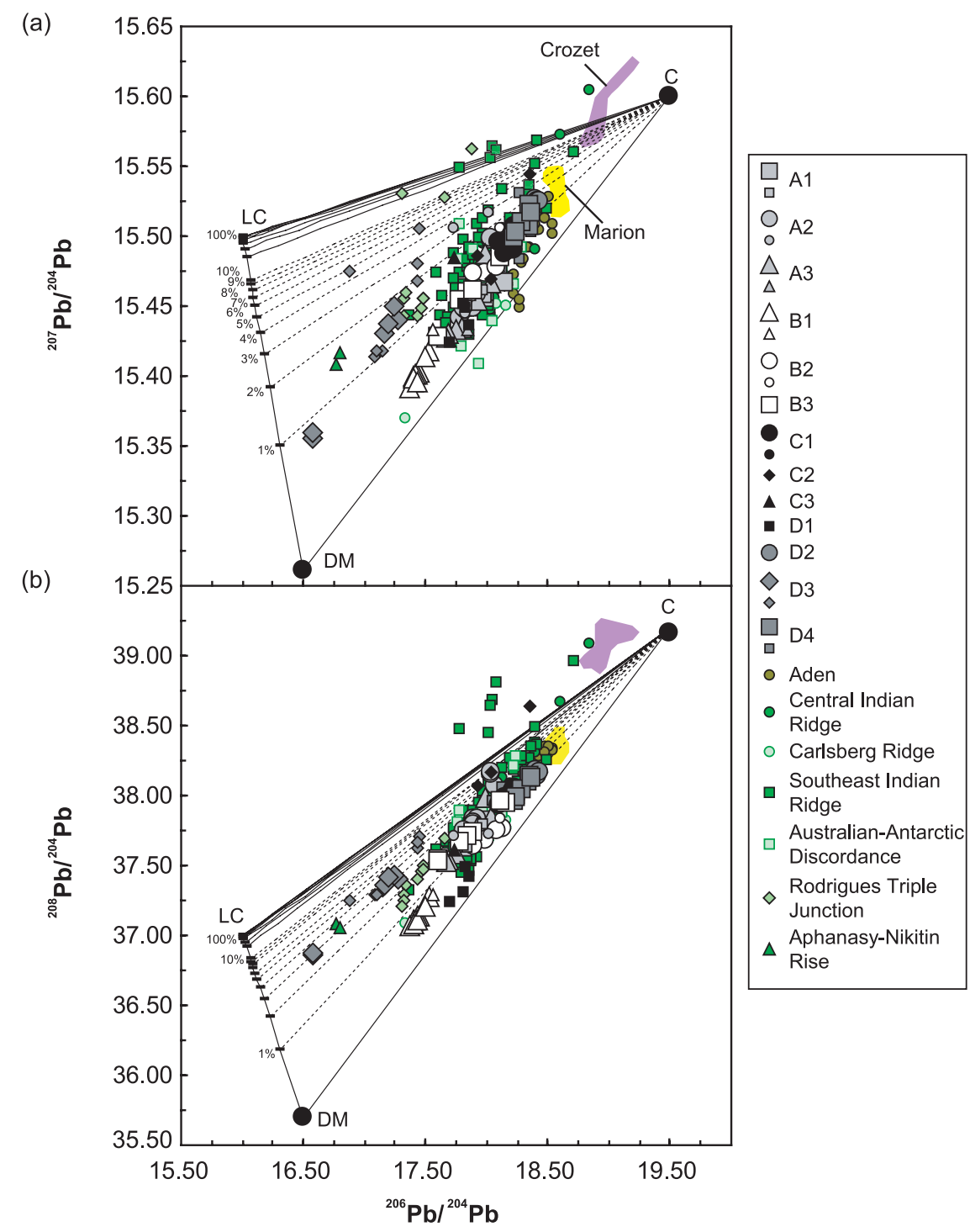

Figure 15. SWIR (a) ${ }^{207} \mathrm{~Pb} /{ }^{204} \mathrm{~Pb}$ and (b) ${ }^{208} \mathrm{~Pb} /{ }^{204} \mathrm{~Pb}$ versus ${ }^{206} \mathrm{~Pb} /{ }^{204} \mathrm{~Pb}$ variations, along with those of other midIndian Ocean ridges (See Auxiliary Material for references used). Also shown are the compositions of the three endmembers (LC, lower crust; C, common component; DM, depleted mantle) as well as modeled mixing lines. The isotopic composition for the $\mathrm{C}$ component is taken from Douglass and Schilling [2000]. The lower crust composition is ${ }^{206} \mathrm{~Pb} /{ }^{204} \mathrm{~Pb}=16.00 ;{ }^{207} \mathrm{~Pb} /{ }^{204} \mathrm{~Pb}=15.50 ;{ }^{208} \mathrm{~Pb} /{ }^{204} \mathrm{~Pb}=37.00 ;{ }^{87} \mathrm{Sr} /{ }^{86} \mathrm{Sr}=0.70800 ;{ }^{143} \mathrm{Nd} /{ }^{144} \mathrm{Nd}=0.511600 ; \mathrm{Sr}=$ $421 \mathrm{ppm} ; \mathrm{Nd}=21 ;$ and $\mathrm{Pb}=2.58$. Sr and $\mathrm{Pb}$ elemental contents are from Rudnick and Fountain [1995]. The $\mathrm{Nd}$ elemental content is in the range of those observed for granulite xenoliths (average: $17.3 \pm 13, \mathrm{~N}=133$ ). The DM composition is ${ }^{206} \mathrm{~Pb} /{ }^{204} \mathrm{~Pb}=16.50 ;{ }^{207} \mathrm{~Pb} /{ }^{204} \mathrm{~Pb}=15.26 ;{ }^{208} \mathrm{~Pb} /{ }^{204} \mathrm{~Pb}=35.70 ;{ }^{87} \mathrm{Sr} /{ }^{86} \mathrm{Sr}=0.701659 ;{ }^{143} \mathrm{Nd} /{ }^{144} \mathrm{Nd}=$ $0.513481 ; \mathrm{Sr}=13 \mathrm{ppm} ; \mathrm{Nd}=0.7$; and $\mathrm{Pb}=0.044$. Marks on the mixing lines between depleted mantle and lower crust are graduated from 1 to $10 \%$, then from 10 to $100 \%$.

component equivalent to Central Atlantic/Pacific depleted mantle; (2) an Indian oceanic islandtype mantle with moderate ${ }^{206} \mathrm{~Pb} /{ }^{204} \mathrm{~Pb}$, high ${ }^{208} \mathrm{~Pb} /{ }^{204} \mathrm{~Pb},{ }^{87} \mathrm{Sr} /{ }^{86} \mathrm{Sr}$, and low ${ }^{143} \mathrm{Nd} /{ }^{144} \mathrm{Nd}$, similar to the "C" component of Hanan and Graham [1997]; and (3) a low ${ }^{206} \mathrm{~Pb} /{ }^{204} \mathrm{~Pb}$ component with relatively high ${ }^{208} \mathrm{~Pb} /{ }^{204} \mathrm{~Pb},{ }^{87} \mathrm{Sr} /{ }^{86} \mathrm{Sr}$ and low ${ }^{143} \mathrm{Nd} /{ }^{144} \mathrm{Nd}$.
[47] Mixing models for the Indian Ocean usually appeal to these three components in two stage mixing events, in which the asthenosphere experienced widespread contamination by the low ${ }^{206} \mathrm{~Pb} /{ }^{204} \mathrm{~Pb}$ component, before being mixed with OIB type material [e.g., Hamelin et al., 1986, Escrig et al., 2004; Douglas and Schilling, 2000]. One variant of such a model is that of 


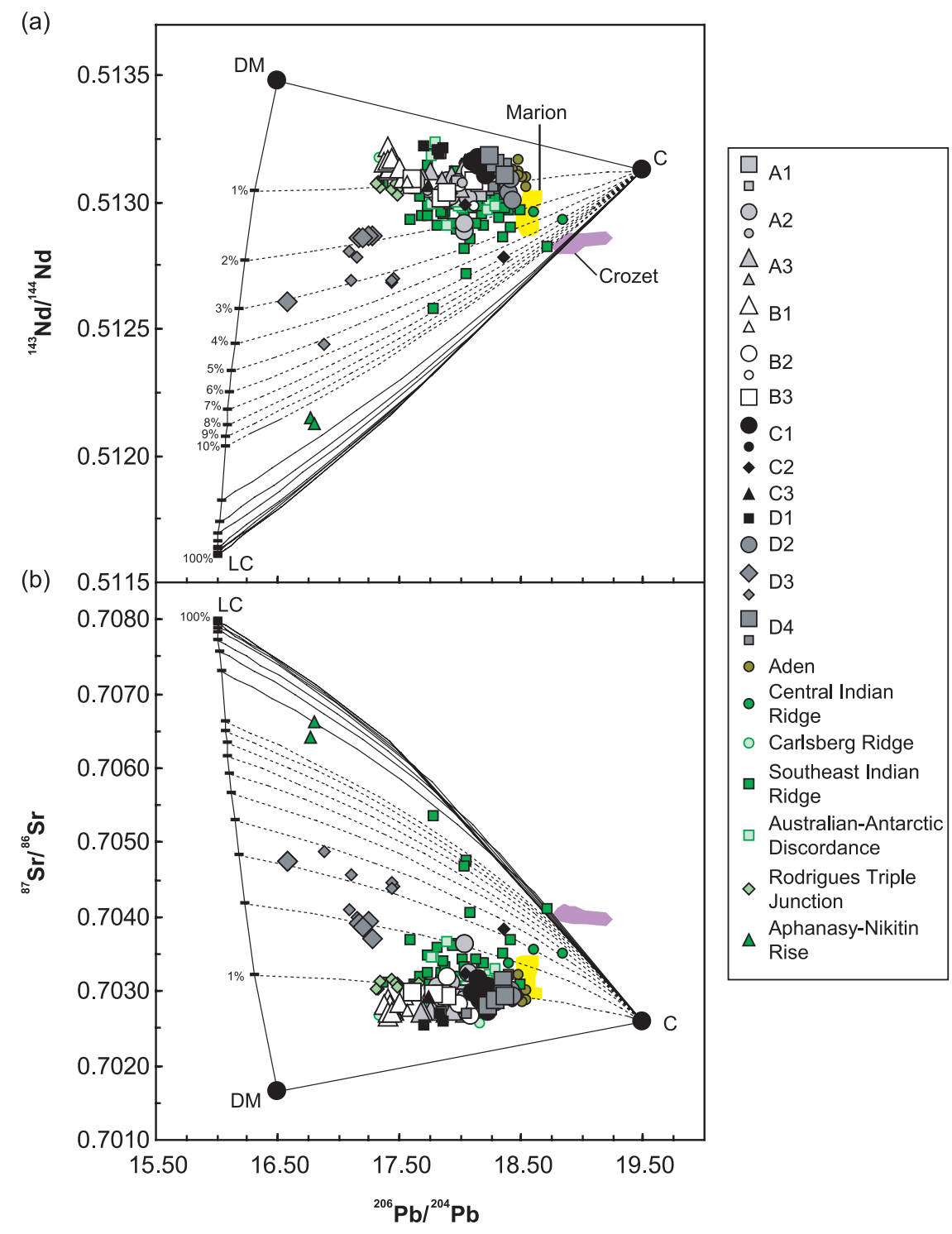

Figure 16. SWIR (a) ${ }^{143} \mathrm{Nd} /{ }^{144} \mathrm{Nd}$ and (b) ${ }^{87} \mathrm{Sr} /{ }^{86} \mathrm{Sr}$ versus ${ }^{206} \mathrm{~Pb} /{ }^{204} \mathrm{~Pb}$ variations, along with those of other midIndian Ocean ridges. Symbols as in Figure 15.

proposed by Barling et al. [1994], in which the entire north Atlantic and Pacific array mixes with a small amount of low ${ }^{206} \mathrm{~Pb} /{ }^{204} \mathrm{~Pb}$ material arising from, in their model, subcontinental lithospheric mantle. We also propose a two-stage, three component mixing model, involving a low ${ }^{206} \mathrm{~Pb} /{ }^{204} \mathrm{~Pb}$ component, a depleted Pacific/Central Atlantic mantle and the $\mathrm{C}$ component of Douglas and Schilling [2000] (Figures 15 and 16). The common component $(\mathrm{C})$ is required to extend the Indian MORB mixing array toward high ${ }^{206} \mathrm{~Pb} /{ }^{204} \mathrm{~Pb}$ and may be provided by numerous plumes in the Indian Ocean (Marion, Crozet, Reunion and Amsterdam). As discussed above, we argue that the origin of the low ${ }^{206} \mathrm{~Pb} /{ }^{204} \mathrm{~Pb}$ component lies in material derived from the lower continental crust, which has been delaminated and injected into the mantle during ancient convergent processes.

[48] Approximately $0.5-3 \%$ of recycled lower crust is sufficient to explain the Indian Ocean population in general, while a maximum contribution of $\sim 6 \%$ is required to account for the composition of the $39-41^{\circ} \mathrm{E}$ section. Although this model can account for most of the isotopic features of Indian MORB, the trends defined by the Aphanasy-Nikitin Rise require much larger amounts of lower crustal component (Figures 15 and 16). These features may be explained if the low ${ }^{206} \mathrm{~Pb} /{ }^{204} \mathrm{~Pb}$ component is more heterogeneous in 
terms of ${ }^{207} \mathrm{~Pb} / 204 \mathrm{~Pb},{ }^{143} \mathrm{Nd} /{ }^{144} \mathrm{Nd}$ and ${ }^{87} \mathrm{Sr} /{ }^{86} \mathrm{Sr}$ than in ${ }^{208} \mathrm{~Pb} /{ }^{204} \mathrm{~Pb}$, a conclusion consistent with the isotopic attributes of African granulite xenoliths (Figures 13 and 14).

\section{Conclusions}

[49] $\mathrm{Sr}-\mathrm{Nd}-\mathrm{Pb}$ isotope systematics for SWIR MORB dredged between 35 and $69^{\circ} \mathrm{E}$ reveal significant heterogeneity of the SWIR mantle over a wide range of length scales. Important isotopic variations occur on local scales, independently of ridge segmentation, which are generally of greater amplitude than those observed on larger scales. The existence of such small scale isotopic domains demonstrate that there has been no vigorous, widespread and long-term convection inducing mantle mixing, and that magma mixing given the present sampling has been restricted to a scale of $\sim 308 \mathrm{~km}$.

[50] Our new data for lavas from the deep easternmost SWIR domain confirm that they differ isotopically from those of the Rodrigues Triple Junction, Southeast Indian Ridge and Central Indian Ridge indicating the existence of an abrupt boundary occurring over an on-axis distance of less than $\sim 78 \mathrm{~km}$.

[51] Our new results for lavas from the $39-41^{\circ} \mathrm{E}$ section, which are considered to represent one of the best indicators of the material responsible for the distinctive Indian mantle signature exhibit the lowest ${ }^{206} \mathrm{~Pb} /{ }^{204} \mathrm{~Pb}$ values (to 16.58 ) yet found among oceanic islands and spreading centers worldwide and confirm their extremely high ${ }^{87} \mathrm{Sr} /{ }^{86} \mathrm{Sr},{ }^{207} \mathrm{~Pb} /{ }^{204} \mathrm{~Pb},{ }^{208} \mathrm{~Pb} /{ }^{204} \mathrm{~Pb}$ and low ${ }^{143} \mathrm{Nd} /{ }^{144} \mathrm{Nd}$. These lavas do not bear any affinity with modern lavas from the nearby Marion hot spot. They also cannot be accounted for by the presence in the source of old sedimentary material, as no present-day group of sediment has parentdaughter attributes (e.g., variable $\mathrm{U} / \mathrm{Pb}$ and constant $\mathrm{Th} / \mathrm{Pb}$ ) similar to those of these lavas, even when dewatering processes are considered. Mixture of old subduction modified mantle with a depleted mantle source of Pacific affinity give not rise to sufficiently high ${ }^{208} \mathrm{~Pb} /{ }^{204} \mathrm{~Pb}$ and ${ }^{207} \mathrm{~Pb} /{ }^{204} \mathrm{~Pb}$ to explain the isotopic features of these lavas. Our preferred interpretation is that the isotopic attributes of this section (low ${ }^{206} \mathrm{~Pb} /{ }^{204} \mathrm{~Pb},{ }^{143} \mathrm{Nd} /{ }^{144} \mathrm{Nd}$ and high ${ }^{207} \mathrm{~Pb} /{ }^{204} \mathrm{~Pb},{ }^{208} \mathrm{~Pb} /{ }^{204} \mathrm{~Pb}$ ) are the result of the presence of stranded lower continental crust embedded in the upper mantle, which has been possibly detached and incorporated during convergent processes.
[52] At a global scale, most of the isotopic attributes of Indian MORB can be accounted by a two stage three component mixing model involving a depleted mantle of Central Atlantic/Pacific affinity, the common component $(\mathrm{C})$ and a fertile low ${ }^{206} \mathrm{~Pb} /{ }^{204} \mathrm{~Pb}$ component, arising from the lower crust.

\section{Acknowledgments}

[53] We are grateful to Tod Waight, Olivier Rouxel, and Laurie Reisberg for assistance with the analytical work and fruitful discussions at CRPG and DLC. We also thank Mathilde Cannat. Funding was provided by CNRS-INSU, Programme Dorsale and a Marie Curie fellowship (HPMFCT-2001-01427). The IFRTP provided access to the Marion Dufresne $\Pi$ for sampling. David Christie and Rex Taylor are gratefully acknowledged for their constructive reviews that helped to improve the manuscript, which also benefited from editorial comments of William White and Daniel Sauter.

\section{References}

Allègre, C. J., B. Hamelin, and B. Dupré (1984), Statistical analysis of isotopic ratios in MORB: The mantle blob cluster model and the convective regime of the mantle, Earth Planet. Sci. Lett., 71, 71-84.

Arndt, N. T., and U. Christensen (1992), The role of lithospheric mantle in continental flood volcanism: Thermal and geochemical constraints, J. Geophys. Res., 97, $10,967-10,981$.

Arndt, N. T., and S. L. Goldstein (1989), An open boundary between lower continental crust and mantle: Its role in crust formation and crustal recycling, Tectonophysics, 161, 201212.

Arndt, N. T., G. K. Czamanske, J. L. Wooden, and V. A. Fedorenko (1993), Mantle and crustal contributions to continental flood volcanism, Tectonophysics, 223, 39-52.

Baker, J. A., D. Peate, T. Waight, and C. M. Meyzen (2004), $\mathrm{Pb}$ isotopic analysis of standards using a ${ }^{207} \mathrm{~Pb}^{204} \mathrm{~Pb}$ double spike and thallium to correct for mass bias with a double focusing MC-ICP-MS, Chem. Geol., 211, 275-303.

Barling, J., S. L. Goldstein, and I. A. Nicholls (1994), Geochemistry of Heard Island (southern Indian Ocean): Characterization of an enriched mantle component and geochemical constraints, J. Petrol., 35, 1017-1053.

Ben Othman, D., W. M. White, and P. J. Patchett (1989), The geochemistry of marine sediments, island arc magma genesis, and crust-mantle recycling, Earth Planet. Sci. Lett., 94, $1-21$.

Cannat, M., C. Rommevaux-Jestin, D. Sauter, C. Deplus, and V. Mendel (1999), Formation of the axial relief at the very slow spreading Southwest Indian Ridge $\left(49^{\circ}-69^{\circ} \mathrm{E}\right), \mathrm{J}$. Geophys. Res., 104, 22,825-22,844.

Carlson, R. W., and A. J. Irving (1994), Depletion and enrichment history of the subcontinental lithospheric mantle: An $\mathrm{Os}, \mathrm{Sr}, \mathrm{Nd}$ and $\mathrm{Pb}$ isotopic study of ultramafic xenoliths from the northwestern Wyoming craton, Earth Planet. Sci. Lett., 126, 457-472.

Chauvel, C., and J. Blichert-Toft (2001), A hafnium isotope and trace element perspective on melting of the depleted mantle, Earth Planet. Sci. Lett., 190(3-4), 137-151. 
Chu, D., and R. Gordon (1999), Evidence for motion between Nubia and Somalia along the Southwest Indian Ridge, Nature, 398, 64-67.

Class, C., D. M. Miller, S. L. Goldstein, and C. H. Langmuir (1999), Distinguishing melt and fluid subduction components in Umnak volcanics, Aleutian arc, Geochem. Geophys. Geosyst., 1(6), doi:10.1029/1999GC000010.

Cohen, R. S., R. K. O’Nions, and J. B. Dawson (1984), Isotope geochemistry of xenoliths from East Africa: Implications for development of mantle reservoirs and their interaction, Earth Planet. Sci. Lett., 68, 209-220.

Collins, W. J. (2003), Slab pull, mantle convection, and Pangaean assembly and dispersal, Earth Planet. Sci. Lett., 205, 225-237.

Currey, J. R., and T. Munasinghe (1991), Origin of the Rajmahal Traps and the $85^{\circ} \mathrm{E}$ Ridge: Preliminary reconstructions of the trace of the Crozet Hotspot, Geology, 19, 1237-1240.

Dosso, L., H. Bougault, P. Beuzard, J. Y. Calvez, and J. L. Loron (1988), The geochemical structure of the Southeast Indian Ridge, Earth Planet. Sci. Lett., 88, 47-59.

Douglass, J., and J.-G. Schilling (2000), Systematics of threecomponent, pseudo-binary mixing lines in $2 \mathrm{D}$ isotope ratio space representations and implications for mantle-plume ridge interactions, Chem. Geol., 163, 1-23.

Douglass, J., J.-G. Schilling, and D. Fontignie (1999), Plumeridge interactions of the Discovery and Shona mantle plumes with the southern mid-Atlantic ridge (40 degrees -55 degrees S), J. Geophys. Res., 104, 2941-2962.

Downes, H., A. J. W. Markwick, P. D. Kempton, and M. F. Thirlwall (2001), The lower crust beneath cratonic north-east Europe: Isotopic constraints from garnet granulite xenoliths, Terra Nova, 13, 395-400.

Dunn, T., and C. Sen (1994), Mineral/matrix partition coefficients for orthopyroxene, plagioclase, and olivine in basaltic to andesitic systems: A combined analytical and experimental study, Geochim. Cosmochim. Acta, 58, 717-733.

Dunstan, L. P., J. W. Gramlich, and I. L. Barnes (1980), Absolute isotopic abundance and the atomic weight of a reference sample of Thallium, J. Res. Natl. Bur. Stand. U.S., 85, $1-10$

Dupré, B., and C. Allègre (1983), Pb-Sr isotope variation in Indian Ocean basalts and mixing phenomena, Nature, 303, $142-146$

Escrig, S., F. Capmas, B. Dupré, and C. J. Allègre (2004), Osmium isotopic constraints on the nature of the DUPAL anomaly from Indian mid-ocean-ridge basalts, Nature, 431, $59-63$.

Francis, T. G. J., and R. W. Raitt (1967), Seismic refraction measurements in the southern Indian Ocean, J. Geophys. Res., 72, 3015-3041.

Galer, S. J., A. W. Abouchami, and J. D. Macdougall (1999), East Pacific Rise MORB through the Pb-isotope looking glass, Eos Trans. AGU, 80(46), Fall Meet. Suppl., F1086.

George, R., S. Turner, C. Hawkesworth, J. Morris, C. Nye, J. Ryan, and S. Zheng (2003), Melting processes and fluid and sediment transport rates along the Alaska-Aleutian arc from an integrated U-Th-Ra-Be isotope study, J. Geophys. Res., 108(B5), 2252, doi:10.1029/2002JB001916.

George, R. M., S. P. Turner, C. J. Hawkesworth, C. R. Bacon, C. J. Nye, P. Stelling, and S. T. Dreher (2004), Chemical versus temporal controls on the evolution of tholeitic and calc-alkaline magmas at two volcanoes in the Alaska-Aleutian arc, J. Petrol., 45, 203-219.

Georgen, J. E., and J. Lin (2002), Three-dimensional passive flow and temperature structure beneath oceanic ridge-ridgeridge triple junctions, Earth Planet. Sci. Lett., 204, 115-132.
Georgen, J., and J. Lin (2003), Plume-transform interaction at ultra-slow spreading ridges: Implications for the Southwest Indian Ridge, Geochem. Geophys. Geosyst., 4(9), 9106, doi:10.1029/2003GC000542.

Georgen, J. E., J. Lin, and H. J. B. Dick (2001), Evidence from gravity anomalies for interactions of the Marion and Bouvet hotpots with the Southwest Indian Ridge: Effects of transform offsets, Earth Planet. Sci. Lett., 187, 283-300.

Georgen, J. E., M. D. Kurz, H. J. B. Dick, and J. Lin (2003), Low ${ }^{3} \mathrm{He} /{ }^{4} \mathrm{He}$ ratios in basalt glasses from the western Southwest Indian Ridge $\left(10^{\circ}-24^{\circ}\right.$ E), Earth Planet. Sci. Lett., 206, $509-528$

Hamelin, B., and C. Allègre (1985), Large scale regional units in the depleted upper mantle revealed by an isotope study of the Southwest Indian Ridge, Nature, 315, 196-199.

Hamelin, B., B. Dupré, and C. J. Allègre (1986), Pb-Sr-Nd isotopic data of Indian Ocean Ridges: New evidence of large-scale mapping of mantle heterogeneities, Earth Planet. Sci. Lett., 76, 288-298.

Hanan, B. B., and D. W. Graham (1997), Lead and helium isotope evidence from oceanic basalts for a common deep source of mantle plume, Science, 272, 991-995.

Hanan, B. B., J. Blichert-Toft, D. G. Pyle, and D. M. Christie (2004), Contrasting origins of the upper mantle revealed by hafnium and lead isotopes from the Southeast Indian Ridge, Nature, 432, 91-94.

Hart, S. R. (1984), A large-scale isotope anomaly in the Southern Hemisphere mantle, Nature, 309, 753-757.

Hart, S. R. (1988), Heterogeneous mantle domains: Signatures, genesis and mixing chronologies, Earth Planet. Sci. Lett., 90, 273-296.

Hawkesworth, C. J., A. J. Erlank, P. D. Kempton, and F. G. Waters (1990), Mantle metasomatism: Isotope and trace element trends in xenoliths from Kimberley, South Africa, Chem. Geol., 85, 19-34.

Hergt, J. M., and C. J. Hawkesworth (1994), The Pb, Sr, and $\mathrm{Nd}$ evolution of the Lau Basin: Implication for mantle dynamics during backarc opening, Proc. Ocean Drill. Program Sci. Results, 135, 505-517.

Hofmann, A. W. (2003), Sampling mantle heterogeneity through oceanic basalts: Isotopes and trace elements, in The Mantle and Core, edited by R. W. Carlson, vol. 2, Treatise on Geochemistry, edited by H. Holland and K. K. Turekian, pp. 61-101, Elsevier, New York.

Hofmann, A. W., and W. M. White (1982), Mantle plumes from ancient oceanic crust, Earth Planet. Sci. Lett., 57, $421-436$.

Holm, P. M. (2002), Sr, Nd and $\mathrm{Pb}$ isotopic composition of in situ lower crust at the Southwest Indian Ridge: Results from ODP Leg 176, Chem. Geol., 184, 195-216.

Huang, Y. M., P. VanCalsteren, and C. J. Hawkesworth (1995), The evolution of the lithosphere in southern Africa: A perspective on the basic granulite xenoliths from kimberlites in South Africa, Geochim. Cosmochim. Acta, 59, 4905-4920.

Ito, E., W. M. White, and C. Göpel (1987), The O, Sr, Nd and $\mathrm{Pb}$ isotope geochemistry of MORB, Chem. Geol., 62, 157176.

Jull, M., and P. B. Kelemen (2001), On the conditions for lower crustal convective instability, J. Geophys. Res., 106, 6423-6446.

Kamenetsky, V. S., R. Maas, N. M. Sushchevskaya, M. D. Norman, I. Cartwright, and A. A. Peyve (2001), Remnants of Gondwanan continental lithosphere in oceanic upper mantle: Evidence from the South Atlantic Ridge, Geology, 29, $243-246$ 
Kay, R. W., and S. M. Kay (1993), Delamination and delamination magmatism, Tectonophysics, 219, 177-189.

Kempton, P. D., C. J. Hawkesworth, and M. Fowler (1991), Geochemistry and isotopic composition of gabbros from layer 3 of the Indian Ocean crust, hole 735B, in Proc. Ocean Drill. Program Sci. Results, 118, 127-144.

Kempton, P. D., J. A. Pearce, T. L. Barry, J. G. Fitton, C. Langmuir, and D. M. Christie (2002), Sr-Nd-Pb-Hf isotope results from ODP Leg 187: Evidence for mantle dynamics of the Australian-Antarctic Discordance and origin of the Indian MORB source, Geochem. Geophys. Geosyst., 3(12), 1074, doi:10.1029/2002GC000320.

Kinzler, R. J., and T. L. Grove (1992), Primary magmas of mid-ocean ridge basalts: 2. Applications, J. Geophys. Res., 97, 6907-6926.

Klein, E. M., and C. H. Langmuir (1987), Global correlations of ocean ridge basalt chemistry with axial depth and crustal thickness, J. Geophys. Res., 92, 8089-8115.

Klein, E. M., C. H. Langmuir, A. Zindler, H. Staudigel, and B. Hamelin (1988), Isotope evidence of mantle convection boundary at the Australian-Antarctic Discordance, Nature, 333, 623-629.

Kramers, J. D. (1977), Lead and strontium isotopes in cretaceous kimberlites and mantle-derived xenoliths from Southern Africa, Earth Planet. Sci. Lett., 34, 419-431.

Kramers, J. D., and I. N. Tolstikhin (1997), Two terrestrial lead isotope paradoxes, forward transport modelling, core formation and the history of the continental crust, Chem. Geol., $139,75-110$.

Kramers, J. D., J. C. M. Roddick, and J. B. Dawson (1983), Trace element and isotope studies on veined, metasomatic and "MARID" xenoliths from Bultfontein, South Africa, Earth Planet. Sci. Lett., 65, 90-106.

Langmuir, C. H., and J. F. Bender (1984), The geochemistry of oceanic basalts in the vicinity of transform faultsObservations and implications, Earth Planet. Sci. Lett., 69, 107-127.

Langmuir, C. H., E. M. Klein, and T. Plank (1992), Petrological systematics of mid-ocean ridge basalts: Constraints on melt generation beneath Ocean ridges, in Mantle Flow and Melt Generation at Mid-Ocean Ridges, Geophys. Monogr. Ser., vol. 71, edited by J. Phipps-Morgan, D. K. Blackmann, and J. M. Sinton, pp. 183-280, AGU, Washington, D. C.

LeRoex, A. P., H. J. B. Dick, and R. L. Fisher (1989), Petrology and geochemistry of MORB from $25^{\circ} \mathrm{E}$ to $46^{\circ} \mathrm{E}$ along the Southwest Indian Ridge: Evidence for contrasting style of mantle enrichment, J. Petrol., 30, 947-986.

Luais, B., P. Télouk, and F. Albarède (1997), Precise and accurate neodymium isotopic measurements by plasma-source mass spectrometry, Geochim. Cosmochim. Acta, 61, 48474854.

Machado, N., J. N. Ludden, C. Brooks, and G. Thompson (1982), Fine-scale isotopic heterogeneity in the sub-Atlantic mantle, Nature, 295, 226-228.

Mahoney, J. J., J. H. Natland, W. M. White, R. Poreda, and S. H. Bloomer (1989), Isotopic and geochemical provinces of the Indian Ocean spreading centers, J. Geophys. Res., 94, 40334052.

Mahoney, J., C. Nicollet, and C. Dupuy (1991), Madagascar basalts: Tracking oceanic and continental sources, Earth Planet. Sci. Lett., 104, 350-363.

Mahoney, J., A. P. LeRoex, Z. Peng, R. L. Fisher, and J. H. Natland (1992), Southwestern limits of Indian ocean ridge mantle and origin of low ${ }^{206} \mathrm{~Pb} /{ }^{204} \mathrm{~Pb}$ mid-ocean ridge basalt: Isotope systematics of the Central Southwest Indian Ridge (17-50E), J. Geophys. Res., 97, 19,771-19,790.
Mahoney, J. J., W. M. White, B. G. J. Upton, C. R. Neal, and R. A. Scrutton (1996), Beyond EM-1: Lavas from AfanasyNikitin Rise and the Crozet Archipelago, Indian Ocean, Geology, 24, 615-618.

Mahoney, J. J., R. Freï, M. L. G. Tejada, and T. F. Nägler (1998), Tracing the Indian Ocean mantle domain through time: Isotopic results from old west Indian, East Thetyan, and South Pacific seafloor, J. Petrol., 39, 1285-1306.

Mahoney, J. J., D. W. Graham, D. M. Christie, K. T. M. Johnson, L. S. Hall, and L. Vonderhaar (2002), Between a hotspot and a cold Spot: Isotopic variations in the Southeast Indian Ridge asthenosphere, 86E-118E, J. Petrol., 43, 1155-1176.

Manhès, G., J. F. Minster, and C. J. Allègre (1978), Comparative uranium-thorium-lead and rubidium-strontium study of the Saint Séverin amphotérite: Consequences for early solar system chronology, Earth Planet. Sci. Lett., 39, 14-24.

Marks, K. M., and A. A. Tikku (2001), Cretaceous reconstructions of East Antarctica, Africa and Madagascar, Earth Planet. Sci. Lett., 186, 479-495.

McDade, P., B. J. Wood, and J. D. Blundy (2003), Near solidus trace element partitioning between Tinaquillo lherzolithe and melt at $1.5 \mathrm{GPa}$, Phys. Earth Planet. Inter., 139, 129-147.

McKenzie, D. P., and M. Bickle (1988), The volume and composition of melt generated by extension of the lithosphere, J. Petrol., 25, 625-679.

McKenzie, D. P., and R. K. O’Nions (1991), Partial melts distributions from inversion of rare earth element concentrations, J. Petrol., 32, 1021-1091.

Mendel, V., D. Sauter, L. M. Parsey, and J. R. Vaney (1997), Segmentation and morphotectonic variations along an ultraslow spreading center: The Southwest Indian Ridge $\left(57^{\circ} \mathrm{E}-\right.$ $\left.70^{\circ} \mathrm{E}\right)$, Mar. Geophys. Res., 19, 505-553.

Mendel, V., D. Sauter, C. Rommevaux-Jestin, P. Patriat, F. Lefebvre, and L. M. Parson (2003), Magmato-tectonic cyclicity at the ultra-slow spreading Southwest Indian Ridge: Evidence from variations of axial volcanic ridge morphology and abyssal hills pattern, Geochem. Geophys. Geosyst., 4(5), 9102, doi:10.1029/2002GC000417.

Meyzen, C. M., M. J. Toplis, E. Humler, J. N. Ludden, and C. Mével (2003), A discontinuity in mantle composition beneath the Southwest Indian Ridge, Nature, 421, 731-733.

Michard, A. R., R. Montigny, and R. Schlich (1986), Geochemistry of the mantle beneath the Rodriguez triple junction and the Southeast Indian ridge, Earth Planet. Sci. Lett., 78, 104-114.

Miller, D. M., S. L. Goldstein, and C. H. Langmuir (1994), Cerium/lead and lead isotope ratios in arc magmas and the enrichment of lead in the continents, Nature, 368, 514-520.

Minshull, T. A., and R. S. White (1996), Thin crust on the flanks of the slow-spreading Southwest Indian Ridge, Geophys. J. Int., 125, 139-148.

Mitchell, N. C. (1991), Distributed extension at the Indian Ocean Triple Junction, J. Geophys. Res., 96, 8019-8043.

Müller, M. R., C. J. Robinson, T. A. Minshull, R. S. White, and M. J. Bickle (1997), Thin crust beneath ocean drilling program borehole $735 \mathrm{~B}$ at the Southwest Indian ridge?, Earth Planet. Sci. Lett., 148, 93-107.

Müller, M. R., T. A. Minshull, and R. S. White (1999), Segmentation and melt supply at the Southwest Indian Ridge, Geology, 27, 867-870.

Müller, M. R., T. A. Minshull, and R. S. White (2000), Crustal structure of the Southwest Indian Ridge at the Atlantis II Fracture Zone, J. Geophys. Res., 105, 25,809-25,828.

Müller, R. D., J.-Y. Royer, and L. A. Lawver (1993), Revised plate motions relative to the hotspots from Atlantic and Indian ocean hotpot tracks, Geology, 21, 275-278. 
Nägler, T. F., and J. D. Kramers (1998), Nd isotopic evolution of the upper mantle during the Precambrian: Models, data and the uncertainty of both, Precambrian Res., 91, 233-252.

Niu, Y., K. D. Collerson, R. Batiza, J. I. Wendt, and M. Regelous (1999), Origin of enriched-type mid-ocean ridge basalt at ridges far from mantle plumes: The East Pacific Rise at $11^{\circ} 20^{\prime} \mathrm{N}$, J. Geophys. Res., 104, 7067-7087.

Parson, L., D. Sauter, V. Mendel, P. Patriat, and R. Searle (1997), Evolution of the axial geometry of the Southwest Indian Ocean Ridge between the Melville Fracture Zone and the Indian Ocean Triple Junction-Implications for segmentation on very slow-spreading ridges, Mar. Geophys. Res., 19, 535-552.

Patriat, P., and J. Segouffin (1988), Reconstruction of the central Indian Ocean, Tectonophysics, 155, 211-234.

Patriat, P., D. Sauter, M. Munschy, and L. Parson (1997), A survey of the Southwest Indian Ridge axis between Atlantis II Fracture Zone and the Indian Ocean Triple Junction: Regional setting and large scale segmentation, Mar. Geophys. Res., 19, 457-480.

Pearson, D. G., and G. M. Nowell (2002), The continental lithospheric mantle: Characteristics and significance as a mantle reservoir, Philos. Trans. R. Soc. London, Ser. A, $360(1800), 2383-2410$.

Plank, T., and C. H. Langmuir (1988), An evaluation of the global variations in the major element chemistry of arc basalts, Earth Planet. Sci. Lett., 90, 349-370.

Plank, T., and C. H. Langmuir (1998), The chemical composition of subducting sediments and its consequences for the crust and mantle, Chem. Geol., 145, 325-394.

Price, R. C., A. K. Kennedy, M. Riggs-Sneeringer, and F. A. Frey (1986), Geochemistry of basalts from the Indian Ocean triple junction: Implications for the generation and evolution of Indian Ocean Ridge basalts, Earth Planet. Sci. Lett., 78, 379-396.

Pyle, D. G., D. M. Christie, and J. J. Mahoney (1992), Resolving an isotopic boundary within the Australian-Antarctic Discordance, Earth Planet. Sci. Lett., 112(1-4), 161-178.

Pyle, D. G., D. M. Christie, J. J. Mahoney, and R. A. Duncan (1995), Geochemistry and geochronology of ancient southeast Indian and southwest Pacific seafloor, J. Geophys. Res., 100(B11), 22,261-22,282.

Rehkämper, M., and A. W. Hofmann (1997), Recycled ocean crust and sediment in Indian Ocean MORB, Earth Planet. Sci. Lett., 147, 93-106.

Rehkämper, M., and K. Mezger (2000), Investigation of matrix effects for $\mathrm{Pb}$ isotope ratio measurements by multiple collector ICP-MS: Verification and application of optimised analytical protocols, J. Anal. Atom. Spectrom., 15, 1451-1460.

Robinson, C. J., M. J. Bickle, T. A. Minshull, R. S. White, and A. R. L. Nichols (2001), Low degree melting under the Southwest Indian Ridge: The roles of mantle temperature, conductive cooling and wet melting, Earth Planet. Sci. Lett., 188, 383-398.

Rommevaux-Jestin, C., C. Deplus, and P. Patriat (1997), Mantle Bouguer anomaly along an ultra-slow spreading ridge: Implications for accretionary processes and comparison with results from Central Mid-Atlantic Ridge, Mar. Geophys. Res., 19, 481-503.

Royer, J. Y., P. Patriat, H. W. Bergh, and C. R. Scotese (1988), Evolution of the Southwest Indian Ridge from the late cretaceous (anomaly 34) to the Middle Eocene (anomaly 20), Tectonophysics, 155, 235-260.

Rudnick, R. L., and D. M. Fountain (1995), Nature and composition of the continental crust: A lower crustal perspective, Rev. Geophys., 33, 267-309.
Rudnick, R. L., and S. L. Goldstein (1990), The Pb isotopic compositions of lower crustal xenoliths and the evolution of lower crustal Pb, Earth Planet. Sci. Lett., 98, 192-207.

Saal, A. E., S. R. Hart, N. Shimizu, E. H. Hauri, and G. D. Layne (1998), $\mathrm{Pb}$ isotopic variability in melt inclusions from oceanic island basalts, Polynesia, Science, 282, $1481-1484$.

Salters, J. M., and H. J. B. Dick (2002), Mineralogy of the mid-ocean-ridge basalt source from neodymium isotopic composition in abyssal peridotites, Nature, 418, 68-72.

Sauter, D., P. Patriat, C. Rommevaux-Jestin, M. Cannat, A. Briais, and Gallieni Shipboard Scientific Party (2001), The Southwest Indian Ridge between $49^{\circ} 15^{\prime} \mathrm{E}$ and $57^{\circ} \mathrm{E}$ : Focused accretion and magma redistribution, Earth Planet. Sci. Lett., 192, 303-317.

Schiano, P., J. L. Birck, and C. J. Allègre (1997), Osmiumstrontium-neodymium-lead isotopic covariations in midocean ridge basalt glasses and the heterogeneity of the upper mantle, Earth Planet. Sci. Lett., 150, 363-379.

Schilling, J. G., R. H. Kingsley, B. H. Hanan, and B. L. McCully (1992), Nd-Sr-Pb isotopic variations along the Gulf of Aden: Evidence for Afar mantle plume-continental lithosphere interaction, J. Geophys. Res., 97, 10,92710,966 .

Schilling, J.-G., R. Kingsley, D. Fontignie, R. Poreda, and S. Xue (1999), Dispersion of the Jan Mayen and Iceland mantle plumes in the arctic: A He-Pb-Nd-Sr isotope tracer study of basalts from the Kolbeinsey, Mohns, and Knipovich Ridges, J. Geophys. Res., 104, 10,543-10,569.

Schmitz, M. D., and S. A. Bowring (2000), The significance of $\mathrm{U}-\mathrm{Pb}$ zircon dates in lower crustal xenoliths from the southwestern margin of the Kaapvaal craton, southern Africa, Chem. Geol., 172, 59-76.

Sclater, J. G., R. L. Fisher, P. Patriat, C. Tapscott, and B. Parsons (1981), Eocene to recent development of the South West Indian Ridge, a consequence of the evolution of the Indian Ocean Triple Junction, Geophys. J. R. Astron. Soc., 64, 587-604.

Shen, Y., and D. Forsyth (1995), Geochemical constraints on initial and final depths of melting beneath mid-ocean ridges, J. Geophys. Res., 100, 2211-2237.

Shinjo, R., J. D. Woodhead, and J. M. Hergt (2000), Geochemical variation within the northern Ryukyu Arc: Magma source compositions and geodynamic implications, Contrib. Mineral. Petrol., 140, 263-282.

Smith, S. E., J. F. Casey, W. B. Bryan, L. Dmitriev, S. Silantyev, and R. Magakyan (1998), Geochemistry of basalts from the Hayes Transform region of the mid-Atlantic Ridge, J. Geophys. Res., 103, 5305-5329.

Smith, W. H. F., and D. T. Sandwell (1997), Global seafloor topography from satellite altimetry and ship depth soundings, Science, 277, 1957-1962.

Storey, M., A. D. Saunders, J. Tarney, I. L. Gibson, M. J. Norry, M. F. Thirlwall, P. Leat, R. N. Thompson, and M. A. Menzies (1989), Contamination of Indian Ocean asthenosphere by the Kerguelen Heard mantle plume, Nature, 338, 574-576.

Storey, M., J. J. Mahoney, A. D. Saunders, R. A. Duncan, S. P. Kelley, and M. F. Coffin (1995), Timing of hotspot-related volcanism and the break-up of Madagascar and India, Science, 267, 852-855.

Storey, M., J. J. Mahoney, and A. D. Saunders (1997), Cretaceous basalts in Madagascar and the transition between plume and continental lithosphere mantle source, in Large Igneous Provinces: Continental, Oceanic, and Planetary Flood Volcanism, Geophys. Monogr. Ser., vol. 100, edited 
by J. J. Mahoney and M. F. Coffin, pp. 95-122, AGU, Washington, D. C.

Stracke, A., M. Bizimis, and V. J. M. Salters (2003), Recycling oceanic crust: Quantitative constraints, Geochem. Geophys. Geosyst., 4(3), 8003, doi:10.1029/2001GC000223.

Sturm, M. E., E. M. Klein, D. W. Graham, and J. L. Karsten (1999), Age constraints on crustal recycling to the mantle beneath the Southern Chile Ridge: $\mathrm{He}-\mathrm{Pb}-\mathrm{Sr}-\mathrm{Nd}$ isotope systematics, J. Geophys. Res., 104, 5097-5114.

Tapscott, C., P. Patriat, R. L. Fisher, J. G. Sclater, H. Hoskins, and B. Parsons (1980), The Indian Ocean Triple Junction, J. Geophys. Res., 85, 4723-4739.

Todt, W., R. A. Cliff, A. Hanser, and A. W. Hofmann (1996), Evaluation of a ${ }^{202} \mathrm{~Pb}^{205} \mathrm{~Pb}$ double spike for high-precision lead isotope analysis, in Earth Processes: Reading the Isotopic Code, Geophys. Monogr. Ser., vol. 95, edited by A. Basu and S. R. Hart, pp. 429-437, Washington, D. C.

Turcotte, D. L. (1989), Dynamics of recycling, in Crust/Mantle Recycling at Convergence Zones, edited by S. R. Hart and L. Gülen, NATO ASI Ser., Ser. C, 258, 245-257.
Weaver, B. L. (1991), The origin of ocean basalt end-member compositions: Trace element and isotopic constraints, Earth Planet. Sci. Lett., 104, 381-397.

Wendt, J. I., M. Regelous, Y. Niu, R. Hekinian, and K. D. Collerson (1999), Geochemistry of lavas from the Garrett Transform Fault: Insights into mantle heterogeneity beneath the eastern Pacific, Earth Planet. Sci. Lett., 173, 271-284.

West, B. P., H. Fujimoto, C. Honko, K. Tamaki, and J. C. Sempéré (1995), A three dimensional gravity study of the Rodriguez Triple Junction and the South-East Indian Ridge, Earth Planet. Sci. Lett., 133, 175-184.

White, W. M., A. W. Hofmann, and H. Puchelt (1987), Isotope geochemistry of Pacific mid-ocean ridge basalts, J. Geophys. Res., 92, 4881-4893.

White, W. M., F. Albarède, and P. Télouk (2000), Highprecision analysis of $\mathrm{Pb}$ isotope ratios by multi-collector ICP-MS., Chem. Geol., 167, 257-270.

Zhang, S.-Q., J. J. Mahoney, X.-X. Mo, A. M. Ghazi, L. Milani, A. J. Crawford, T.-Y. Guo, and Z.-D. Zhao (2005), Evidence for a widespread Thetyan upper mantle with Indian-Oceantype isotopic characteristics, J. Petrol., 46, 829-858. 